\title{
Water-Quality in the North Santiam River Basin, Oregon- Comparison of Water-Quality Data for Water Year 2007 with the Preceding Period of Record
}

By David R. Piatt, Matthew W. Johnston, Heather M. Bragg, Amy M. Brooks, Steven Sobieszczyk, and Mark A. Uhrich

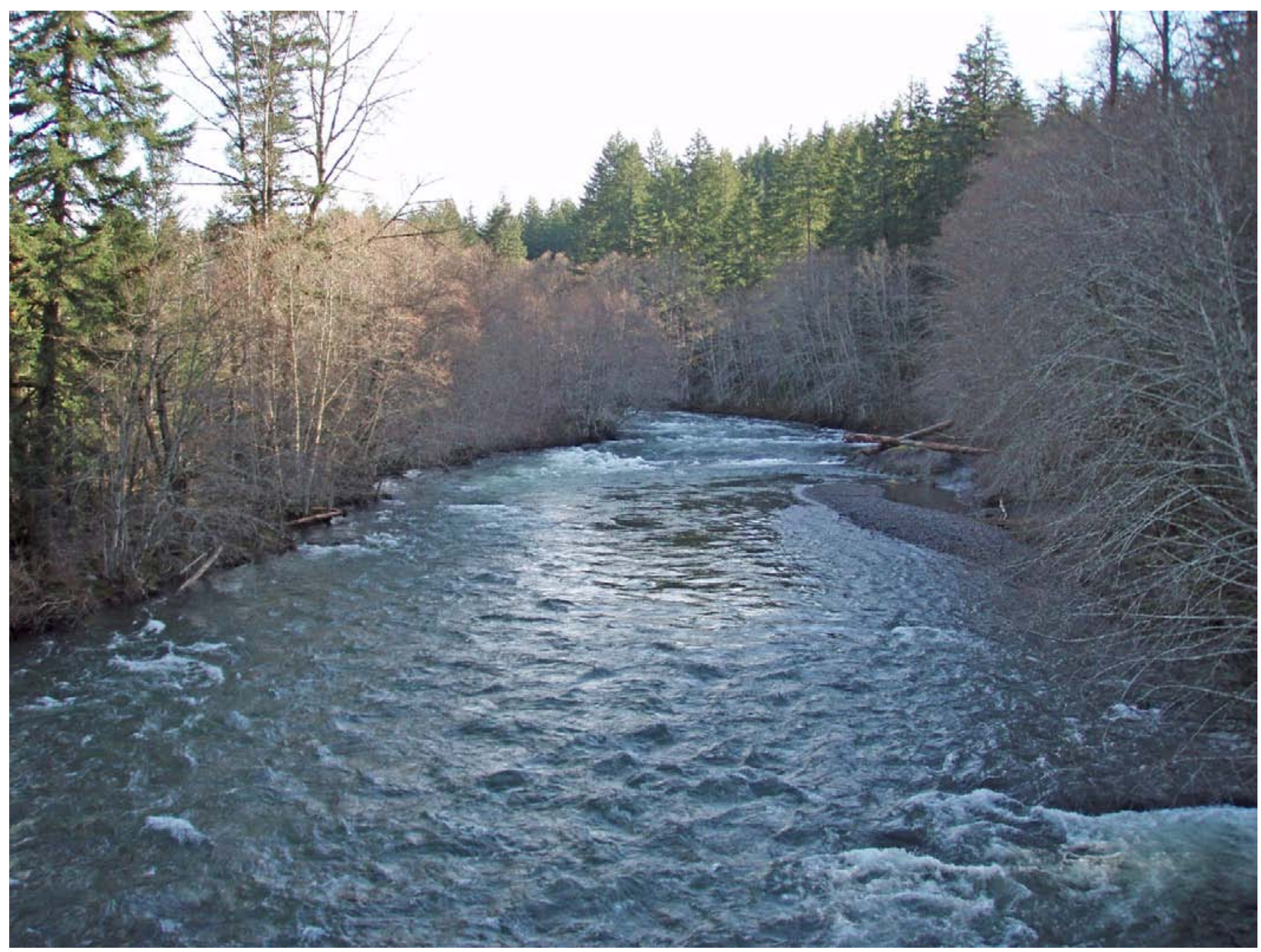

Prepared in cooperation with the City of Salem, Oregon

Open-File Report 2011-1008

U.S. Department of the Interior

U.S. Geological Survey 
Cover: North Santiam River near confluence with Detroit Lake, January 25, 2011. (Photograph by David Piatt, U.S. Geological Survey.) 


\section{Water-Quality in the North Santiam River Basin, Oregon- Comparison of Water-Quality Data for Water Year 2007 with the Preceding Period of Record}

By David R. Piatt, Matthew W. Johnston, Heather M. Bragg, Amy M. Brooks, Steven Sobieszczyk, and Mark A. Uhrich.

Prepared in Cooperation with the City of Salem, Oregon

Open-File Report 2011-1008

U.S. Department of the Interior

U.S. Geological Survey 


\section{U.S. Department of the Interior \\ KEN SALAZAR, Secretary}

\section{U.S. Geological Survey \\ Marcia K. McNutt, Director}

U.S. Geological Survey, Reston, Virginia: 2011

For more information on the USGS —-the Federal source for science about the Earth, its natural and living resources, natural hazards, and the environment, visit http://www.usgs.gov or call 1-888-ASK-USGS.

For an overview of USGS information products, including maps, imagery, and publications, visit $h$ ttp://www.usgs.gov/pubprod

To order this and other USGS information products, visit http://store.usgs.gov

Suggested citation:

Piatt, D.R., Johnston, M.W., Bragg, H.M.,Brooks, A.M., Sobieszczyk, Steven, and Uhrich, M.A., 2011, Water-quality in the North Santiam River basin, Oregon-Comparison of water-quality data for water year 2007 with the preceding period of record: U.S. Geological Survey Open-File Report 2011-1008, 75 p.

Any use of trade, product, or firm names is for descriptive purposes only and does not imply endorsement by the U.S. Government.

Although this report is in the public domain, permission must be secured from the individual copyright owners to reproduce any copyrighted material contained within this report. 


\section{Contents}

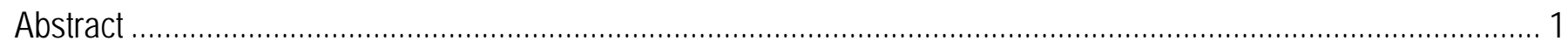

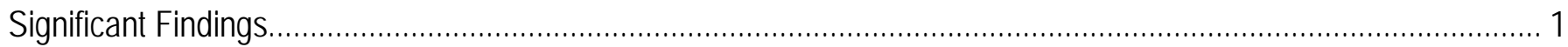

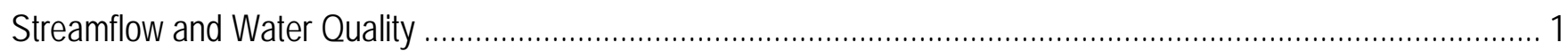

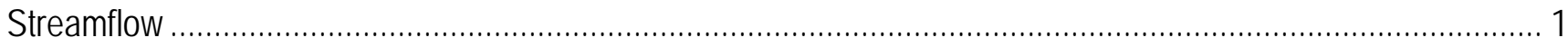

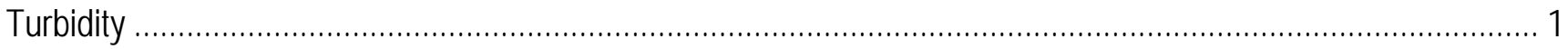

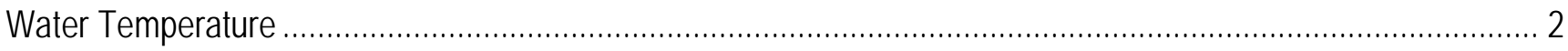

$\mathrm{pH}$

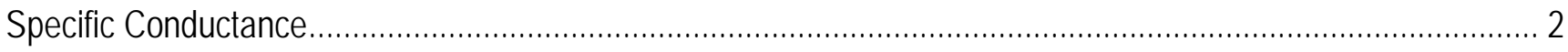

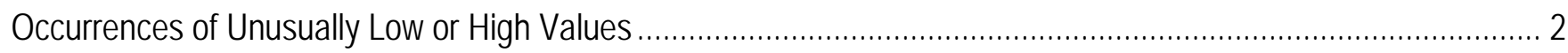

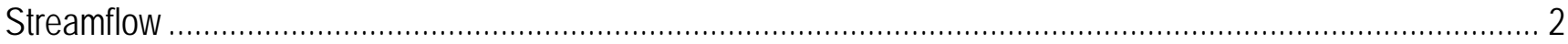

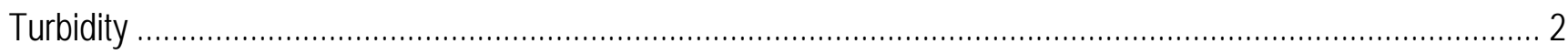

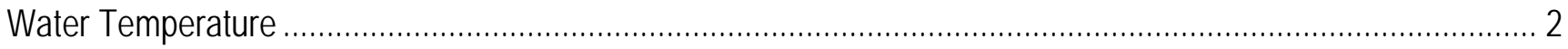

$\mathrm{pH}$

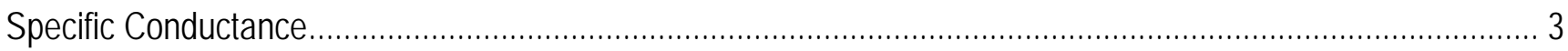

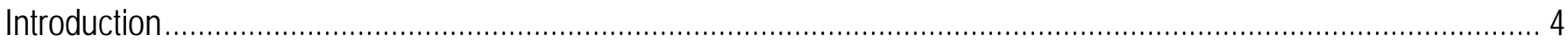

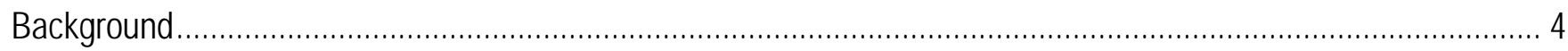

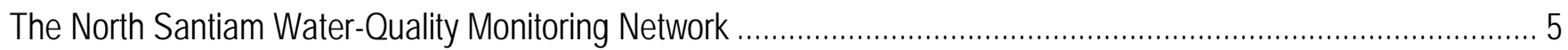

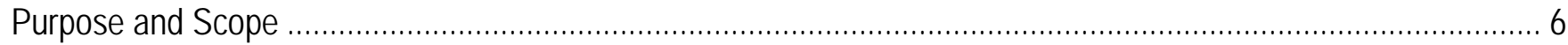

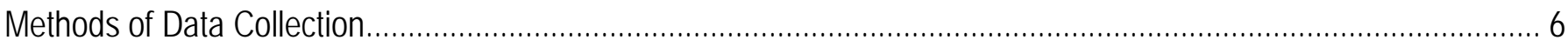

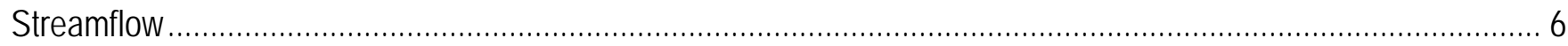

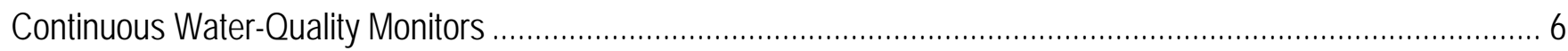

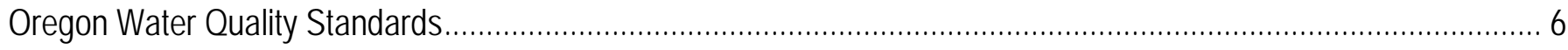

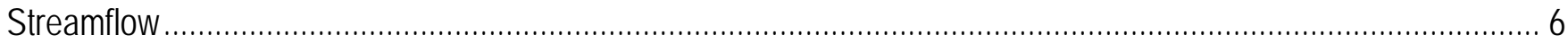

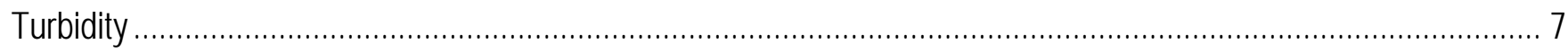

Water Temperature

$\mathrm{pH}$

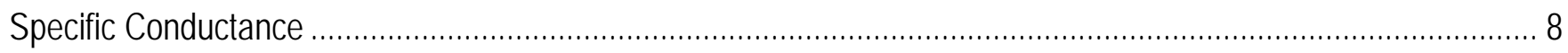

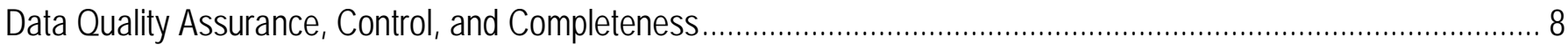

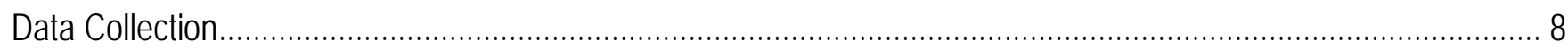

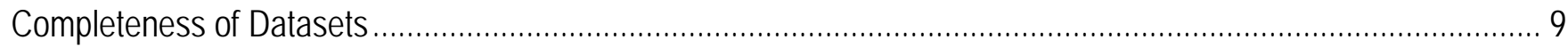

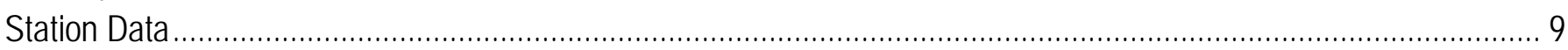

North Santiam River below Boulder Creek near Detroit, Oregon (North Santiam) ..........................................10

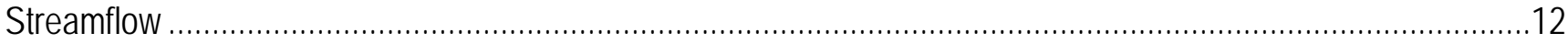

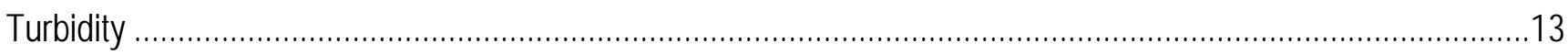

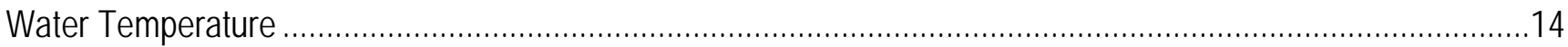

$\mathrm{pH}$

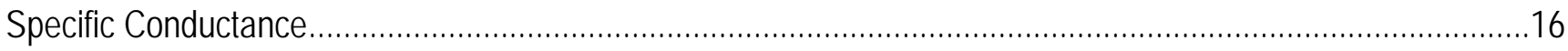

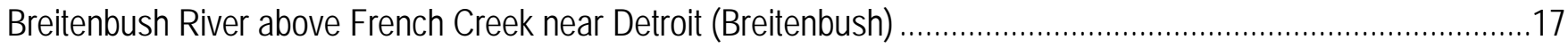

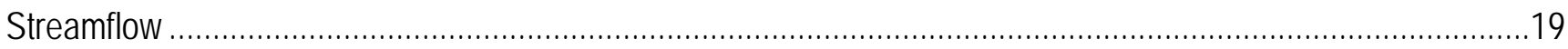




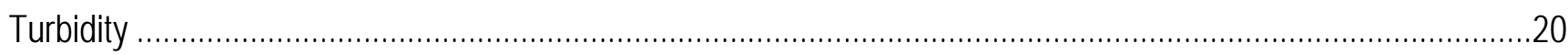

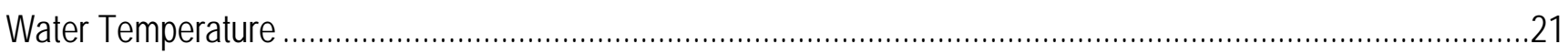

$\mathrm{pH}$

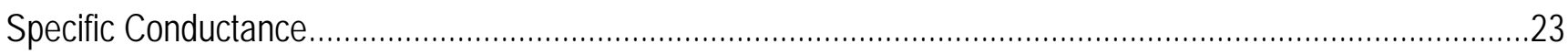

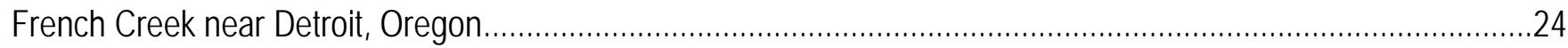

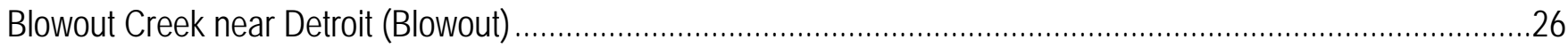

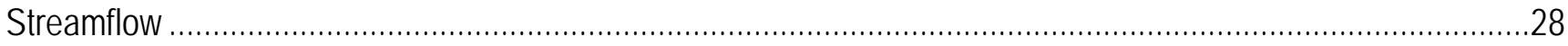

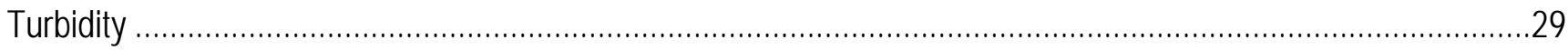

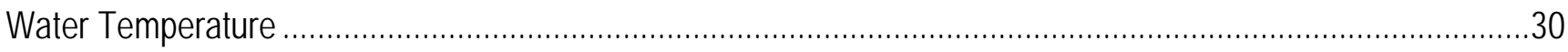

$\mathrm{pH}$

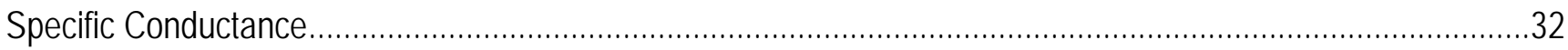

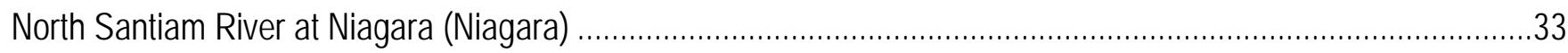

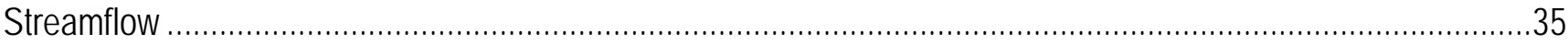

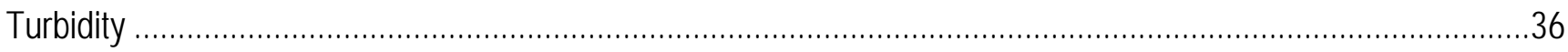

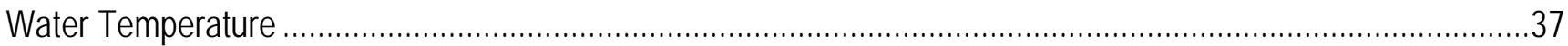

$\mathrm{pH}$

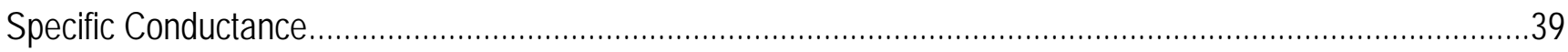

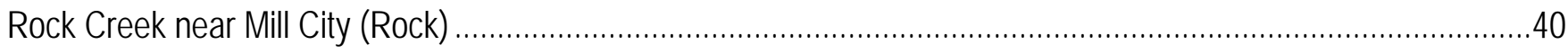

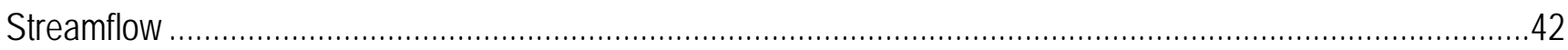

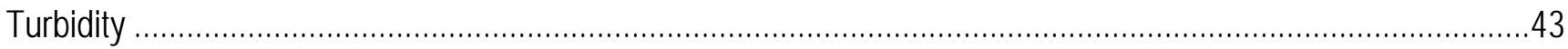

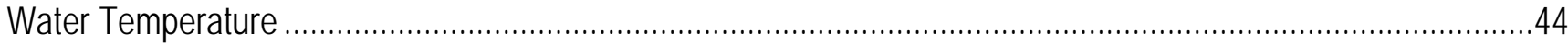

$\mathrm{pH}$

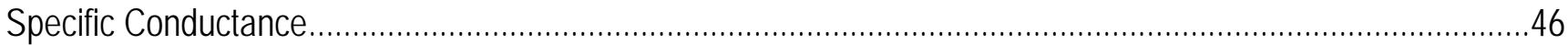

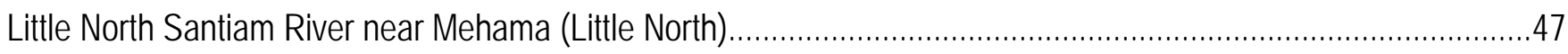

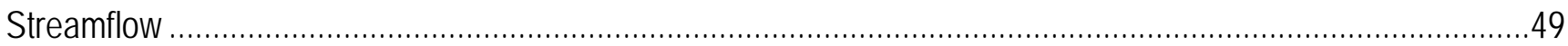

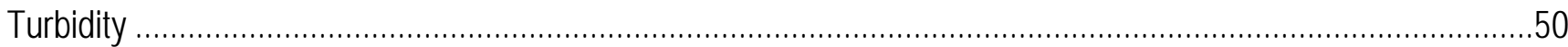

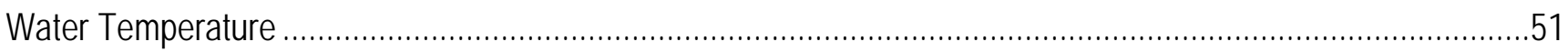

$\mathrm{pH}$

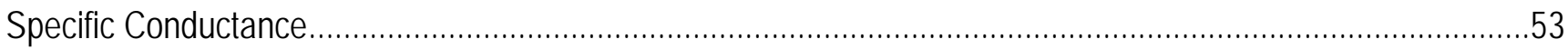

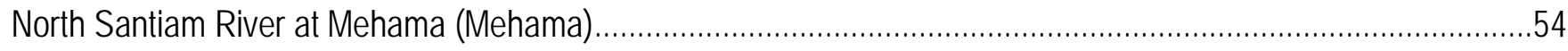

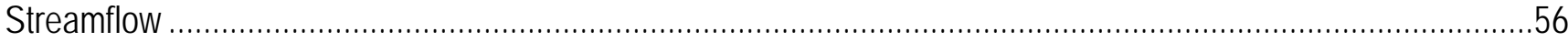

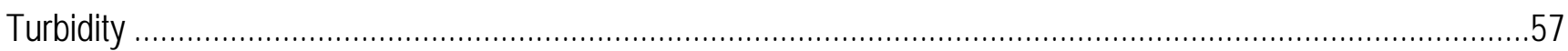

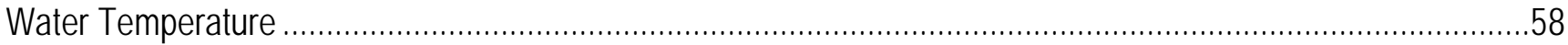

$\mathrm{pH}$

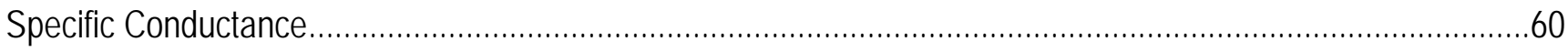

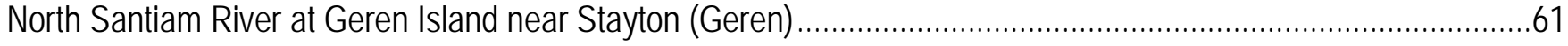

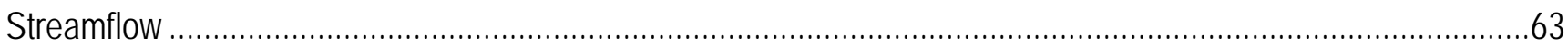

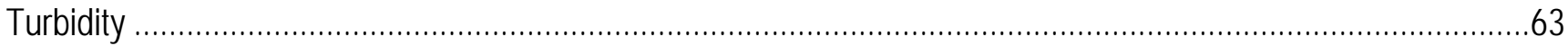

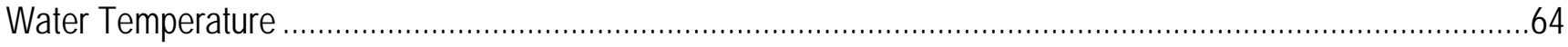

$\mathrm{pH}$

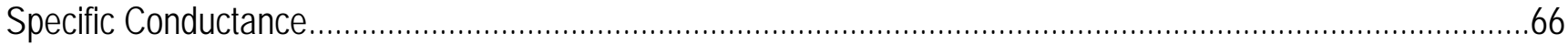




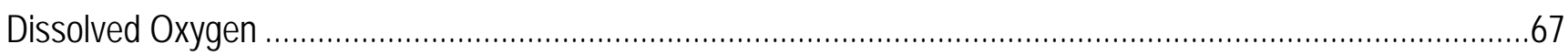

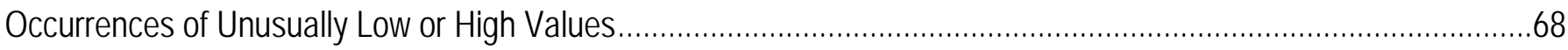

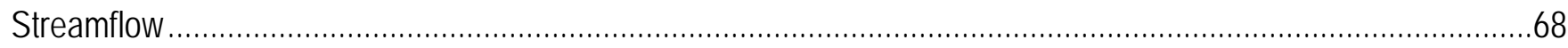

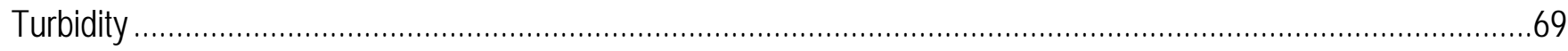

Water Temperature

$\mathrm{pH}$

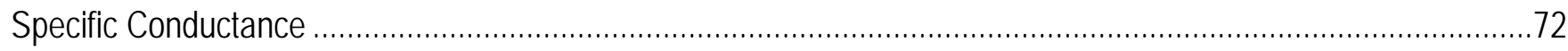

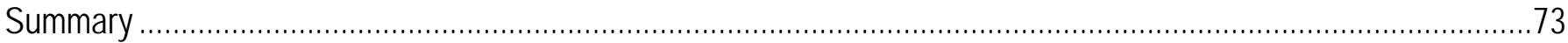

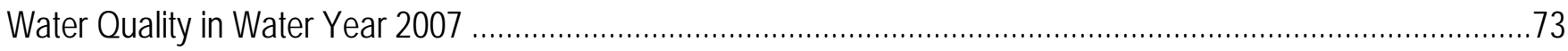

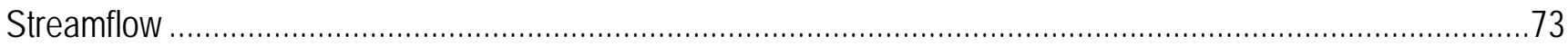

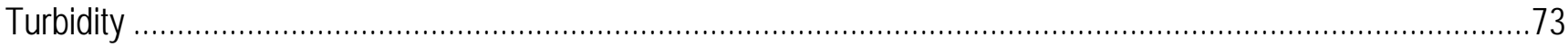

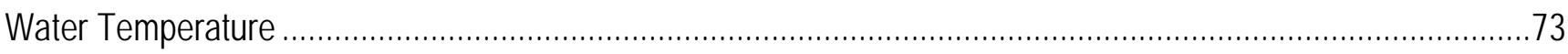

$\mathrm{pH}$

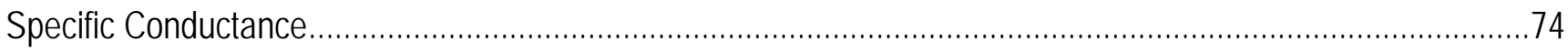

Acknowledgements.

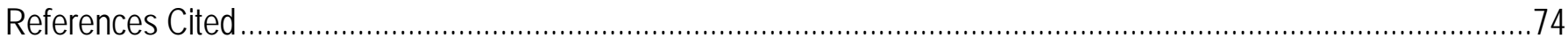

\section{Figures}

Figure 1. Map showing the North Santiam River Basin, Oregon, and the USGS water-quality monitoring network. .... 4

Figure 2. Diagram explaining a box and whisker diagram. ..................................................................... 9

Figure 3. Graphs showing continuous values recorded at the North Santiam monitoring station, North Santiam River

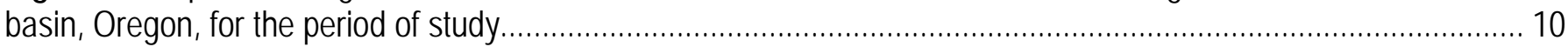

Figure 4. Graphs showing comparison of monthly water year 2007 streamflow, turbidity, water temperature, pH, and specific conductance to water year 1999-2006 values recorded at the North Santiam monitoring station, North Santiam River basin, Oregon....

Figure 5. Graph showing comparison of water year 2007 streamflow data with combined data from water years 1999-2006 recorded at the North Santiam monitoring station, North Santiam River basin, Oregon.

Figure 6. Graph showing comparison of water year 2007 turbidity data with combined data from water years 19992006 recorded at the North Santiam monitoring station, North Santiam River basin, Oregon.

Figure 7. Graph showing comparison of water year 2007 water temperature data with combined data from water years 1999-2006 recorded at the North Santiam monitoring station, North Santiam River basin, Oregon.

Figure 8. Graph showing comparison of water year $2007 \mathrm{pH}$ data with combined data from water years 1999-2006 recorded at the North Santiam monitoring station, North Santiam River basin, Oregon.

Figure 9. Graph showing comparison of water year 2007 specific conductance data with combined data from water years 1999-2006 recorded at the North Santiam monitoring station, North Santiam River basin, Oregon.

Figure 10. Graphs showing continuous values recorded at the Breitenbush monitoring station, North Santiam River basin, Oregon, for the period of study....

Figure 11. Graphs showing comparison of monthly water year 2007 streamflow, turbidity, water temperature, $\mathrm{pH}$, and specific conductance to water year 1999-2006 values recorded at the Breitenbush monitoring station, North Santiam River basin, Oregon.

Figure 12. Graph showing comparison of water year 2007 streamflow data with combined data from water years 1999-2006 recorded at the Breitenbush monitoring station, North Santiam River basin, Oregon. 
Figure 13. Graph showing comparison of water year 2007 turbidity data with combined data from water years 19992006 recorded at the Breitenbush monitoring station, North Santiam River basin, Oregon.

Figure 14. Graph showing comparison of water year 2007 water temperature data with combined data from water years 1999-2006 recorded at the Breitenbush monitoring station, North Santiam River basin, Oregon.

Figure 15. Graph showing comparison of water year $2007 \mathrm{pH}$ data with combined data from water years 1999-2006 recorded at the Breitenbush monitoring station, North Santiam River basin, Oregon.

Figure 16. Graph showing comparison of water year 2007 specific conductance data with combined data from water years 1999-2006 recorded at the Breitenbush monitoring station, North Santiam River basin, Oregon.

Figure 17. Graphs showing combined monthly streamflow, turbidity, water temperature, $\mathrm{pH}$, and specific conductance values for water years 2002-05 recorded at the French monitoring station, North Santiam River basin, Oregon.

Water temperature monitoring began in July 2001.

Figure 18. Graphs showing continuous values recorded at the Blowout monitoring station, North Santiam River

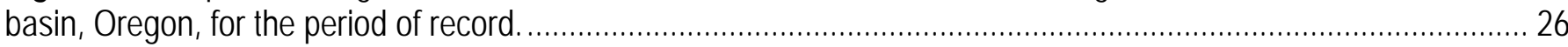

Figure 19. Graphs showing comparison of monthly water year 2007 streamflow, turbidity, water temperature, $\mathrm{pH}$, and specific conductance to water year 1999-2006 values recorded at the Blowout monitoring station, North Santiam River basin, Oregon.

Figure 20. Graph showing comparison of water year 2007 streamflow data with combined data from water years 1999-2006 recorded at the Blowout monitoring station, North Santiam River basin, Oregon.

Figure 21. Graph showing comparison of water year 2007 turbidity data with combined data from water years 19992006 recorded at the Blowout monitoring station, North Santiam River basin, Oregon.

Figure 22. Graph showing comparison of water year 2007 water temperature data with combined data from water years 1999-2006 recorded at the Blowout monitoring station, North Santiam River basin, Oregon.

Figure 23. Graph showing comparison of water year $2007 \mathrm{pH}$ data with combined data from water years 1999-2006 recorded at the Blowout monitoring station, North Santiam River basin, Oregon.

Figure 24. Graph showing comparison of water year 2007 specific conductance data with combined data from water years 1999-2006 recorded at the Blowout monitoring station, North Santiam River basin, Oregon.

Figure 25. Graphs showing continuous values recorded at the Niagara monitoring station, North Santiam River basin, Oregon, for the period of study.

Figure 26. Graphs showing comparison of monthly water year 2007 streamflow, turbidity, water temperature, pH, and specific conductance to water year 2000-06 values recorded at the Niagara monitoring station, North Santiam River basin, Oregon.

Figure 27. Graph showing comparison of water year 2007 streamflow data with combined data from water years 2000-06 recorded at the Niagara monitoring station, North Santiam River basin, Oregon.

Figure 28. Graph showing comparison of water year 2007 turbidity data with combined data from water years 2000 06 recorded at the Niagara monitoring station, North Santiam River basin, Oregon.

Figure 29. Graph showing comparison of water year 2007 water temperature data with combined data from water years 2000-06 recorded at the Niagara monitoring station, North Santiam River basin, Oregon.

Figure 30. Graph showing comparison of water year $2007 \mathrm{pH}$ data with combined data from water years 2000-06 recorded at the Niagara monitoring station, North Santiam River basin, Oregon.

Figure 31. Graph showing comparison of water year 2007 specific conductance data with combined data from water years 2000-06 recorded at the Niagara monitoring station, North Santiam River basin, Oregon. 39

Figure 32. Graphs showing continuous values recorded at the Rock monitoring station, North Santiam River basin, Oregon, for the period of record. 
Figure 33. Graphs showing comparison of monthly water year 2007 streamflow, turbidity, water temperature, $\mathrm{pH}$, and specific conductance to water year 2006 values recorded at the Rock monitoring station, North Santiam River basin, Oregon......

Figure 34. Graph showing comparison of water year 2007 streamflow data with the water year 2006 record for the Rock monitoring station, North Santiam River basin, Oregon.

Figure 35. Graph showing comparison of water year 2007 turbidity data with the water year 2006 record for the Rock monitoring station, North Santiam River basin, Oregon.

Figure 36. Graph showing comparison of water year 2007 water temperature data with the water year 2006 record for the Rock monitoring station, North Santiam River basin, Oregon.

Figure 37. Graph showing comparison of water year 2007 pH data with the water year 2006 record for the Rock monitoring station, North Santiam River basin, Oregon.

Figure 38. Graph showing comparison of water year 2007 specific conductance data with the water year 2006 record for the Rock monitoring station, North Santiam River basin, Oregon.

Figure 39. Graphs showing continuous values recorded at the Little North monitoring station, North Santiam River basin, Oregon, for the period of study.....

Figure 40. Graphs showing comparison of monthly water year 2007 streamflow, turbidity, water temperature, $\mathrm{pH}$, and specific conductance to water year 2000-06 values recorded at the Little North monitoring station, North Santiam River basin, Oregon.

Figure 41. Graph showing comparison of water year 2007 streamflow data with combined data from water years 2000-06 recorded at the Little North monitoring station, North Santiam River basin, Oregon.

Figure 42. Graph showing comparison of water year 2007 turbidity data with combined data from water years 200006 recorded at the Little North monitoring station, North Santiam River basin, Oregon.

Figure 43. Graph showing comparison of water year 2007 water temperature data with combined data from water years 2000-06 recorded at the Little North monitoring station, North Santiam River basin, Oregon......

Figure 44. Graph showing comparison of water year 2007 pH data with combined data from water years 2000-06 recorded at the Little North monitoring station, North Santiam River basin, Oregon.

Figure 45. Graph showing comparison of water year 2007 specific conductance data with combined data from water years 2000-06 recorded at the Little North monitoring station, North Santiam River basin, Oregon......

Figure 46. Graphs showing continuous values recorded at the Mehama monitoring station, North Santiam River basin, Oregon, for the period of study....

Figure 47. Graphs showing comparison of monthly water year 2007 streamflow, turbidity, water temperature, pH, and specific conductance to water year 2000-06 values recorded at the Mehama monitoring station, North Santiam River basin, Oregon.

Figure 48. Graph showing comparison of water year 2007 streamflow data with combined data from water years 2000-06 recorded at the Mehama monitoring station, North Santiam River basin, Oregon.....

Figure 49. Graph showing comparison of water year 2007 turbidity data with combined data from water years 200006 recorded at the Mehama monitoring station, North Santiam River basin, Oregon.....

Figure 50. Graph showing comparison of water year 2007 water-temperature data with combined data from water years 2000-06 recorded at the Mehama monitoring station, North Santiam River basin, Oregon.

Figure 51. Graph showing comparison of water year 2007 pH data with combined data from water years 2000-06 recorded at the Mehama monitoring station, North Santiam River basin, Oregon.

Figure 52. Graph showing comparison of water year 2007 specific conductance data with combined data from water years 2000-06 recorded at the Mehama monitoring station, North Santiam River basin, Oregon. 
Figure 53. Graphs showing continuous values recorded at the Geren monitoring station, North Santiam River basin, Oregon, for the period of record through water year 2007.

Figure 54. Graphs showing comparison of monthly water year 2007 turbidity, water temperature, $\mathrm{pH}$, and specific conductance to water year 2001-06 values recorded at the Geren monitoring station, North Santiam River basin, Oregon......

Figure 55. Graph showing comparison of water year 2007 turbidity data with combined data from water years 200106 recorded at the Geren monitoring station, North Santiam River basin, Oregon. 63

Figure 56. Graph showing comparison of water year 2007 water temperature data with combined data from water years 2001-06 recorded at the Geren monitoring station, North Santiam River basin, Oregon.

Figure 57. Graph showing comparison of water year $2007 \mathrm{pH}$ data with combined data from water years 2001-06 recorded at the Geren monitoring station, North Santiam River basin, Oregon

Figure 58. Graph showing comparison of water year 2007 specific conductance data with combined data from water years 2001-06 recorded at the Geren monitoring station, North Santiam River basin, Oregon.

Figure 59. Graph showing dissolved oxygen data for part of water year 2003 and all of water year 2004 from the Geren monitoring station, North Santiam River basin, Oregon.

Figure 60. Graph showing the percentage of streamflow values recorded at monitoring stations in the North Santiam River basin, Oregon, that exceeded the p5 and p95 threshold values in water year 2007 and during the period of record preceding water year 2007.

Figure 61. Graph showing the percentage of turbidity values recorded at monitoring stations in the North Santiam River basin, Oregon, that exceeded the $10 \mathrm{FNU}$ and $50 \mathrm{FNU}$ threshold in water year 2007 and during the period of record preceding water year 2007.

Figure 62. Graph showing the percentage of water temperature values recorded at monitoring stations in the North Santiam River basin, Oregon, that exceeded the $13^{\circ} \mathrm{C}, 16^{\circ} \mathrm{C}$, and $18^{\circ} \mathrm{C}$ threshold values in water year 2007 and during the period of record preceding water year 2007.

Figure 63. Graph showing the percentage of $\mathrm{pH}$ values recorded at monitoring stations in the North Santiam River basin, Oregon, that exceeded the 6.5 and 8.5 standard unit threshold values in water year 2007 and during the period of record preceding water year 2007.

Figure 64. Graph showing the percentage of specific conductance values recorded at monitoring stations in the North Santiam River basin, Oregon, that exceeded the 30 and $50 \mu \mathrm{S} / \mathrm{cm}$ threshold values in water year 2007 and during the period of record preceding water year 2007.

\section{Tables}

Table 1. Water-quality monitoring stations in the North Santiam River basin, Oregon. 


\section{Conversion Factors, Datum, and Abbreviations and Acronyms}

\section{Conversion Factors}

\begin{tabular}{lll}
\hline \multicolumn{1}{c}{ Multiply } & \multicolumn{1}{c}{ By } & \multicolumn{1}{c}{ To obtain } \\
\hline foot $(\mathrm{ft})$ & 0.3048 & meter $(\mathrm{m})$ \\
mile (mi) & 1.609 & kilometer $(\mathrm{km})$ \\
square mile $\left(\mathrm{mi}^{2}\right)$ & 2.590 & square kilometer $\left(\mathrm{km}^{2}\right)$ \\
cubic foot $\left(\mathrm{ft}^{3}\right)$ & 0.02832 & cubic meter $\left(\mathrm{m}^{3}\right)$ \\
cubic foot per second $\left(\mathrm{ft}^{3} / \mathrm{s}\right)$ & 0.02832 & cubic meter per second $\left(\mathrm{m}^{3} / \mathrm{s}\right)$ \\
\hline
\end{tabular}

Temperature in degrees Celsius ( $\mathrm{C}$ ) may be converted to degrees Fahrenheit $\left({ }^{\circ} \mathrm{F}\right)$ as follows:

\section{${ }^{\circ} \mathrm{F}=\left(1.8 x^{\circ} \mathrm{C}\right)+32$.}

Specific conductance is reported in microsiemens per centimeter at 25 degrees Celsius ( $\mu \mathrm{S} / \mathrm{cm}$ at $25^{\circ} \mathrm{C}$ ).

Water year is the 12-month period from October 1 through September 30 and is identified by the calendar year in which it ends.

For example, the period October 1, 2006, through September 30, 2007, is designated water year 2007.

\section{Datum}

Horizontal datum information is referenced to the North American Datum of 1927 (NAD 27).

\section{Abbreviations and Acronyms}

$\begin{array}{ll}\text { DCP } & \text { data collection platform } \\ \text { FNU } & \text { formazin nephelometic units } \\ \text { NTU } & \text { nephelometric turbidity units } \\ \text { p5 } & \text { 5th percentile } \\ \text { P95 } & \text { 95th percentile } \\ \text { WY } & \text { water year }\end{array}$


This page is intentionally blank. 


\title{
Water-Quality in the North Santiam River Basin, Oregon- Comparison of Water-Quality Data for Water Year 2007 with the Preceding Period of Record
}

By David R. Piatt, Matthew W. Johnston, Heather M. Bragg, Amy M. Brooks, Steven Sobieszczyk, and Mark A. Uhrich.

\begin{abstract}
Water-quality data have been collected in the North Santiam River basin since 1998. During water year 2007, eight monitoring stations were operated throughout the basin. Streamflow data were collected at all but one of these sites. This report presents a comparison of the water-quality and streamflow data collected at each monitoring station from monitor installation through water year 2006 with the data for water year 2007. Data were compiled monthly and annually to identify extreme values by season and for entire periods of study.
\end{abstract}

\section{Significant Findings}

\section{Streamflow and Water Quality}

Streamflow

- $\quad$ On the basis of recorded streamflows, the North Santiam River basin had a normal to wet winter and a dry summer in water year (WY) 2007.

- Period-of-study peak streamflows occurred in late November-December of WY 2007 at all lower basin sites except at the North Santiam River at Niagara monitoring station (Niagara).

- In contrast, during October-early November of WY 2007, monthly streamflows at all tributary stations except Breitenbush River near Detroit (Breitenbush) were the lowest for the period of study.

Turbidity

- Coincident with the high streamflows, new monthly peak turbidities were established for all stations except Breitenbush and Blowout Creek near Detroit (Blowout) during NovemberDecember of WY 2007.

- A maximum turbidity value for the period of study was established in WY 2007 at all lower basin sites. In the upper basin, the peak turbidity at North Santiam River below Boulder Creek (North Santiam) followed a debris flow upstream of the monitoring station. The turbidity was known to be much higher than the sensor maximum value of 1,600 formazin nephelometric units (FNU) because of samples collected at the site. The peak values at North Santiam River near 
Niagara (Niagara) occurred when sediment from the debris flow reached the monitor several days after the event.

\section{Water Temperature}

- Most water temperatures during WY 2007 were similar to those recorded in past years. All stations recorded temperatures greater than $16^{\circ} \mathrm{C}$, the Core Cold Water Habitat standard, and, in the upper basin, Blowout recorded temperatures greater than $18^{\circ} \mathrm{C}$, the Rearing and Migration standard.

- Seventy-five percent or more of January 2007 water temperatures were near to or cooler than pre-WY 2007 median temperatures at all sites.

$\mathrm{pH}$

- The annual ranges of pH values in WY 2007 were generally similar to pre-2007 values at all stations.

- Some monthly peak values of pH in summer of WY 2007 were greater than pre-2007 values. New peak values were established at all three lower basin mainstem stations.

\section{Specific Conductance}

- Median summer WY 2007 specific conductance values were higher than pre-WY 2007 median specific conductance during most months at most stations. Median winter specific conductance values during WY 2007 were lower than pre-WY 2007 median values for much of the basin. However the ranges in WY 2007 were comparable to those in previous years.

\section{Occurrences of Unusually Low or High Values}

Streamflow

- Streamflow recorded at all stations except Niagara was less than the 5th percentile in WY 2007.

- Streamflow recorded at all stations was greater than the 95th percentile in WY 2007.

\section{Turbidity}

- Turbidity recorded at all stations in the basin was greater than 50 FNU in WY 2007. In previous water years, turbidity values at all stations, except Niagara, also exceeded 50 FNU in at least some years.

- However, at all stations except Rock Creek near Mill City (Rock, which had only 2 years of data) the percentage of values greater than 50 FNU was greater in WY 2007 than in prior years.

Water Temperature

- Temperatures recorded at all stations, before WY 2007 and in WY 2007, were greater than $16^{\circ} \mathrm{C}$, the Core Cold Water Habitat Use standard, at some time.

- Blowout was the only upper-basin station where recorded water temperature exceeded $18^{\circ} \mathrm{C}$, the Rearing and Migration State Standard, in WY 2007 and in prior years. 
$\mathrm{pH}$

- Only the Little North Santiam River near Mehama (Little North) and North Santiam River at Mehama (Mehama) stations have recorded $\mathrm{pH}$ values less than 6.5 during the period of study; the rate of occurrence in all years was about 1 percent or less.

- Only North Santiam, Little North, Mehama, and North Santiam River at Geren Island (Geren) have recorded $\mathrm{pH}$ values greater than 8.5 at some time during the period of record.

- Exceedences of the pH standard of 8.5 were recorded only at Mehama and Geren in WY 2007, in about 4 percent or less of the data.

\section{Specific Conductance}

- All stations had at least 1 percent of values less than $30 \mu \mathrm{S} / \mathrm{cm}$ in pre-WY 2007 and WY 2007 records.

- Lower-basin stations had a greater percentage of values than upper-basin stations that were less than the minimum threshold value of $30 \mu \mathrm{S} / \mathrm{cm}$, and pre-2007 and WY 2007 percentages of exceedence were similar for both datasets.

- All the upper-basin stations and only the lower-basin tributaries had values greater than 50 $\mu$ S/cm for pre-WY 2007 and WY 2007, the only exception being Blowout in WY 2007. 


\section{Introduction}

The North Santiam River (fig. 1) is the primary drinking water source for the residents of the City of Salem and other communities in the basin. More than 177,000 people in the surrounding area receive drinking water from the river. Because the river is used as a drinking water source, local agencies continuously monitor the raw-water quality. Monitoring the river conditions in near real time allows agencies to determine when to take action in the event of adverse water-quality conditions, ensuring that the finished drinking water meets all State of Oregon and City of Salem treatment plant requirements. Monitoring also enables the analysis of geomorphological processes (erosion and sedimentation, which can result in excess turbidity) and water-quality issues (high $\mathrm{pH}$ and water temperature) that can negatively affect aquatic life.

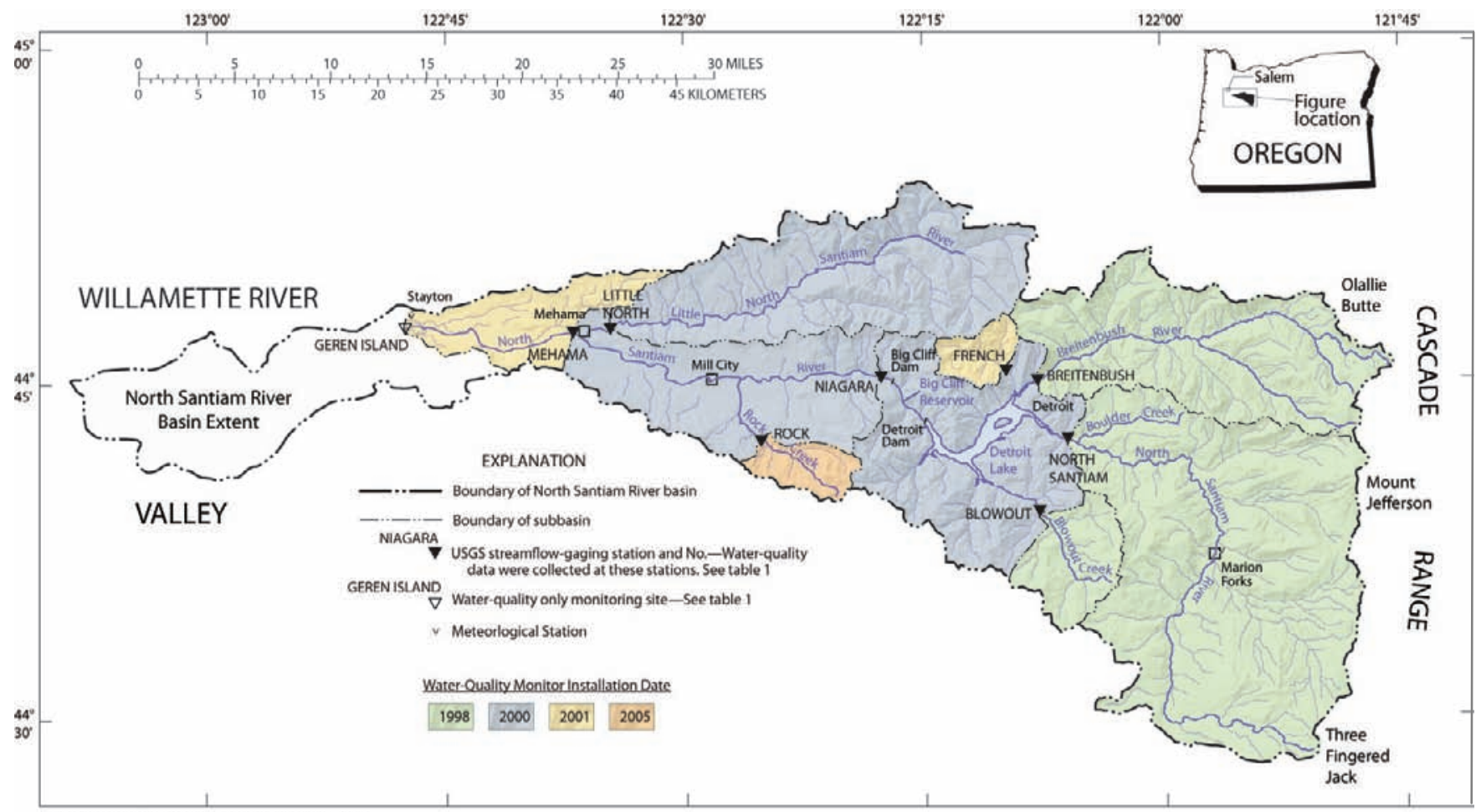

Base map modified from U.S. Geological Survey and

other digital data sets $(1: 24,000)$. UTM projection, Zone 10,

Horizontal daturm: North American Datum of 1927

Figure 1. Map showing the North Santiam River Basin, Oregon, and the USGS water-quality monitoring network.

\section{Background}

In February 1996, heavy rainfall and melting snow caused streams in the North Santiam River basin to flood to greater than 50-year recurrence levels, greatly increasing suspended sediment loads and forcing the closure of the City of Salem's drinking water-treatment plant for 8 days (Uhrich and Bragg, 2003; Cooper, 2005; Sobieszczyk and others, 2007). Excessive, persistent turbidity necessitated the costly pretreatment of water for several months after the storm to prevent clogging of the City's slowsand-filtration system (Sobieszczyk and others, 2007). In response to the floods, the City of Salem, in cooperation with the U.S. Geological Survey (USGS), initiated the North Santiam River Basin Suspended-Sediment and Turbidity Study. Continuous water-quality data for the study are recorded at several stations on the North Santiam River and its larger tributaries (Bragg and Uhrich, 2005). 


\section{The North Santiam Water-Quality Monitoring Network}

The monitoring network (fig. 1, table 1) is used to identify suspended-sediment and turbidity events as they occur so that water-treatment plant operators can respond accordingly. Data from the network are also used to identify sources of turbidity in the basin, such as landslides, which might in some cases allow remediation that would lessen the frequency of high-turbidity events.

In addition to turbidity, the water-quality monitors record water temperature, specific conductance, and $\mathrm{pH}$. Stream stage (level) is measured at all the monitoring stations except Geren Island (Geren; see table 1 for explanations of station name abbreviations), the most downstream station, where the monitor is in a concrete, regulated channel. Streamflow at Geren is determined from a rating developed between stage and field measurements of streamflow. Suspended-sediment data are collected throughout the basin with manual samplers and automated pumping samplers over a range of streamflow and turbidity conditions (Uhrich and Bragg, 2003; Bragg and others, 2007; Sobieszczyk and others, 2007).

Table 1. Water-quality monitoring stations in the North Santiam River basin, Oregon.

["Period of record" includes the period of this study, station installation date through water year 2007.]

\begin{tabular}{|c|c|c|c|c|c|c|}
\hline $\begin{array}{l}\text { Station } \\
\text { reference }\end{array}$ & Station name & $\begin{array}{c}\text { Station } \\
\text { abbreviation }\end{array}$ & $\begin{array}{c}\text { USGS Station } \\
\text { number }\end{array}$ & $\begin{array}{c}\text { Drainage basin } \\
\text { area } \\
\text { (square } \\
\text { miles) }\end{array}$ & $\begin{array}{l}\text { Period of } \\
\text { record } \\
\text { (water year) }\end{array}$ & $\begin{array}{l}\text { Years of } \\
\text { record }\end{array}$ \\
\hline North Santiam & $\begin{array}{l}\text { North Santiam River } \\
\text { below Boulder Creek } \\
\text { near Detroit }\end{array}$ & BCKO & 14178000 & 216 & 1999-2007 & 9 \\
\hline Breitenbush & $\begin{array}{l}\text { Breitenbush River } \\
\text { above French Creek } \\
\text { near Detroit }\end{array}$ & $\mathrm{BRBO}$ & 14179000 & 108 & 1999-2007 & 9 \\
\hline French & $\begin{array}{l}\text { French Creek near } \\
\text { Detroit }\end{array}$ & N/A & 14179100 & 10 & 2002-2006 & 5 \\
\hline Blowout & $\begin{array}{l}\text { Blowout Creek near } \\
\text { Detroit }\end{array}$ & BLOW & 14180300 & 26 & 1999-2007 & 9 \\
\hline Niagara & $\begin{array}{l}\text { North Santiam River } \\
\text { at Niagara }\end{array}$ & NIAG & 14181500 & 453 & 2000-2007 & 8 \\
\hline Rock & $\begin{array}{l}\text { Rock Creek near Mill } \\
\text { City }\end{array}$ & ROCK & 14181750 & 15 & 2006-2007 & 2 \\
\hline Little North & $\begin{array}{l}\text { Little North Santiam } \\
\text { River near Mehama }\end{array}$ & LSMO & 14182500 & 112 & $2000-2007$ & 8 \\
\hline Mehama & $\begin{array}{l}\text { North Santiam River } \\
\text { at Mehama }\end{array}$ & MEHO & 14183000 & 655 & $2000-2007$ & 8 \\
\hline Geren & $\begin{array}{l}\text { North Santiam River } \\
\text { at Geren Island near } \\
\text { Stayton }\end{array}$ & GEREN & 4447281224500 & 688 & 2001-2007 & 7 \\
\hline
\end{tabular}




\section{Purpose and Scope}

This report presents streamflow, turbidity, water temperature, $\mathrm{pH}$, and specific conductance data for all stations in the North Santiam water-quality monitoring network for the period of study from the date of instrument installation through WY 2007. At most stations, collection of streamflow and water quality data is ongoing. Water-quality data from WY 2007 are compared with data from the preceding period of study for each station. (WY 2007 was noteworthy because of the effects of a debris flow and a large storm in early November 2006 and subsequent high-flow events later in November and December.) Additionally, new minimums and maximums, as well as exceedences of State standards, are reported.

\section{Methods of Data Collection}

Instrumentation at each station consists of a Yellow Springs Instruments (YSI ${ }^{\circledR}$ ) model 6920 multiparameter water-quality sonde (hereinafter called a monitor), data collection platform (DCP), and stream-stage measuring equipment. All stations are telemetered by telephone, cellular phone, radio, or satellite. Data are recorded every 15 or 30 minutes, depending on the station, by the DCP and are transmitted multiple times daily. Additionally, 15-minute data, including stream depth at most stations (except Blowout Creek near Detroit [Blowout] and Geren), are recorded internally by the water-quality monitor to provide redundancy and a measure of quality control.

\section{Streamflow}

Stream stage (level) used in streamflow calculations is measured with either a Sutron shaft encoder with an electric tape gage as a reference gage or pressure sensor that measures the back pressure produced on nitrogen gas that is bubbled into the river. Data are collected and analyzed in accordance with USGS protocols in Rantz and others (1982). The depth sensor on the YSI ${ }^{\circledR}$ monitor is used for backup data, for quality control, and as a primary source for streamflow calculation if the gaging equipment is damaged.

\section{Continuous Water-Quality Monitors}

Water quality is monitored by YSI 6920 multiparameter monitors equipped to measure and record water temperature, specific conductance, $\mathrm{pH}$, turbidity, and depth (on most units and at most stations). An explanation of the water-quality parameters measured can be found in Wagner and others (2006)'

\section{Oregon Water Quality Standards}

Federal and State regulations govern the minimum and/or maximum allowable values for certain water-quality parameters as they pertain to uses of a body of water. Oregon water quality guidelines and regulations are available in a publication by the State of Oregon (2008).

\section{Streamflow}

No State standards have been established for streamflow. Threshold values of the 5th and 95th percentile streamflows were established for purposes of highlighting extreme streamflow values in this report. In streamflow data, “p5” and "p95” refer to the 5th and 95th percentile streamflows, respectively. The stream discharge calculations on which p5 and p95 are based include, where applicable, only the data that were recorded after the installation of Detroit and Big Cliff Dams, starting in WY 1955. At stations not affected by the dams, p5 and p95 were calculated using all available data, 
which in some cases date back 75 years or more. The actual p5 and p95 values were calculated using the entire period of study; however, the percentage of values that exceed p5 and p95 were calculated using period of study data, through WY 2006. The calculations are based on daily mean values. Streamflows that are less than the 5th percentile are considered to be atypically low, and streamflows that are greater than the 95th percentile are considered to be atypically high. Ninety percent of the data are between these two values. The significance of streamflow values is station specific. Although p5 and p95 conditions are sometimes referred to as "drought" or "flood" streamflows, that designation is not always correct. A stream with a narrow range of streamflows would not be considered "flooded' when the water rises $1 \mathrm{ft}$, but this increase can be enough for the streamflow to be greater than the 95th percentile. Thus, the purpose of the p5 and p95 values is only to indicate statistically low or high streamflow, respectively, for a given water system.

\section{Turbidity}

Turbidity is a measurement of the cloudiness of water, caused primarily by suspended sediment. Suspended sediment can act as a substrate onto which harmful chemicals may bind and can adversely affect aquatic organisms through habitat degradation. At turbidity values greater than 10 formazin nephelometric units (FNU), sediment can clog slow sand-filtration systems, like the ones used by the drinking-water treatment facility at the City of Salem, unless a pretreatment, such as a roughing filter, is used. (The State of Oregon measures turbidity in nephelometric turbidity units [NTU], which is roughly similar to FNU [Anderson, 2005].) Statewide, anthropogenic sources may contribute no more than a 10 percent cumulative increase in natural stream turbidities unless authorization has been granted (State of Oregon, 2008).

\section{Water Temperature}

Water temperature standards have the goal of protecting key temperature-sensitive biological species from anthropogenic causes of water temperature increases that exceed an acceptable level for that species (State of Oregon, 2008). The standards are primarily intended to protect salmonid species from unnaturally warm waters during vulnerable periods in their life cycles. The standard applies an average 7-day running maximum and varies depending on salmonid usage of a part of the river during a specified period. The lower basin, downstream of Detroit and Big Cliff Dams and including the Little North Santiam River and Rock Creek, is designated Coldwater and Spawning Habitat. September 1June 15 (the spawning period) has a Biological Numeric Criterion of $13^{\circ} \mathrm{C}$, and June 16-August 31 (the nonspawning period) has a Biological Numeric Criterion of $16^{\circ} \mathrm{C}$. All of the North Santiam River basin and its tributaries upstream of Big Cliff Dam are designated as Rearing and Migration Habitat for the full year. The Biological Numeric Criterion is $18^{\circ} \mathrm{C}$. Temperature cannot exceed the criteria during the times indicated at the locations specified.

The State standard applies a 7-day moving average of the daily maximum water temperature when it defines a violation. In this report, no running average has been applied to the data. The graphs of temperature in this report are of instantaneous values recorded every 15 or 30 minutes, and references to values exceeding or not exceeding standards applies to those data, not to running averages. Therefore, exceedences do not necessarily constitute violations. Further, no determination was made of whether anthropogenic or natural sources contributed to exceedences. 
$\mathrm{pH}$

$\mathrm{pH}$ is a measure of the relative acidity or alkalinity of water. Water with a $\mathrm{pH}$ of 7 is neutral; increasingly lower $\mathrm{pH}$ values indicate increasing acidity, whereas $\mathrm{pH}$ values increasingly higher than 7 indicate an increasingly basic (alkaline) solution. Similar to water temperature, $\mathrm{pH}$ has a direct influence on which organisms can exist in a water body. Aquatic organisms typically cannot thrive or survive in water with a $\mathrm{pH}$ outside of a specific range. Further, water becomes undrinkable or otherwise unusable by humans at $\mathrm{pH}$ values greater than or less than those within a certain range. The Oregon Department of Environmental Quality has set the State standard for $\mathrm{pH}$ to between 6.5 and 8.5 in the Willamette River basin and its tributaries, which includes the North Santiam River. No determination was made during this study of whether natural or anthropogenic sources were the cause of recorded values outside of the established acceptable range of $\mathrm{pH}$ values.

\section{Specific Conductance}

The State of Oregon has no standards for specific conductance. For purposes of this report, the values of 30 and $50 \mu \mathrm{S} / \mathrm{cm}$ have been assigned as minimum and maximum thresholds, respectively. In the North Santiam River basin, values outside of this range typically occur only during special circumstances, such as high streamflow events. Specific conductance values in the North Santiam River basin differ among subbasins. A value outside of the 30-50 $\mu \mathrm{S} / \mathrm{cm}$ range is not necessarily indicative of a problem. Specific conductance in the North Santiam River basin has not been problematic because the values are low.

\section{Data Quality Assurance, Control, and Completeness}

Water-quality data are collected and classified in accordance with established USGS protocols (Wagner and others, 2006). Data are reported in USGS water data reports (U.S. Geological Survey, 2009) and more information is available in those reports. All data are reviewed at least twice before being published.

\section{Data Collection}

Water quality in the North Santiam River basin has been continuously monitored since October 1998 at some locations, with stations being added in succeeding years (fig. 1, table 1). The additional stations were equipped to measure the same parameters as the original stations. Monitors are visited every 3 or 4 weeks or as access permits. (Access often is limited by snowfall and road conditions in winter.) Data are corrected for probe fouling and calibration drift, and some corrections are added, as needed, to allow for data continuity when a monitor or probe malfunctions. Data that are determined to be erroneous are deleted from the dataset.

Methodology for correcting and reporting data has changed through the years. Early in the history of the project, protocols were not available to allow corrections other than for fouling or calibration; currently, a correction may be applied for reasons that include probe failure and malfunction. Data reporting has changed in the number of significant figures reported (currently, some data are rounded that were not rounded several years ago) and in reporting units. Turbidity previously was reported in NTU, but currently is reported in FNU. More information about turbidity measurement and reporting is available in Anderson (2005). Negative turbidity values are not possible; however, because of probe tolerances, negative turbidity values have been recorded. Ending in WY 2005, values less than 1 FNU, including negative values, were reported in the USGS annual Water Data Report (U.S. Geological 
Survey, 2009) as “less than 1 FNU.” Beginning in WY 2006, values less than 1 FNU have been reported in the USGS annual Water Data Report to the nearest 0.1 FNU; negative values are corrected and reported as 0 FNU. Turbidity probes have a maximum measurement threshold of 1,200-1,800 FNU, depending on the instrument; these values are reported as "greater than 1,000 FNU."

\section{Completeness of Datasets}

Erroneous data and malfunctioning equipment cause datasets to be incomplete. Data that are incorrect are adjusted, if possible, to reflect the trend of the data before and after the error. When data cannot be corrected or the error is significantly large (as defined in Wagner and others, 2006), the data are deleted. Malfunctioning equipment can cause data gaps. Whenever possible, the gaps are filled by backup data that are then corrected. If backup data are unavailable, incomplete, or incorrect, the gap remains in the data.

\section{Station Data}

The graphs in this section show data from each monitoring station for the period of study in three ways: (1) continuous values, (2) boxplots (box and whisker plots) of combined data for the period of study prior to WY 2007 and for WY 2007, by month, and (3) boxplots of combined annual data for the period of study prior to WY 2007 and for WY 2007. An explanation of a box and whisker diagram is shown in figure 2. In a box and whisker diagram, data values are ordered from lowest to highest and divided into "quartiles" (quarters). The first quartile contains the lowest 25 percent of the data, the second contains the next 25 percent of the data, and so on. The middle half of the data (the interquartile range, or 25th to 75th percentile) is indicated by the box, and the "whiskers" show the range of values less than and greater than the interquartile range. The median, which is the midpoint of the data, the point at which half of the values are above that point and half below, is indicated by the bar within the box.

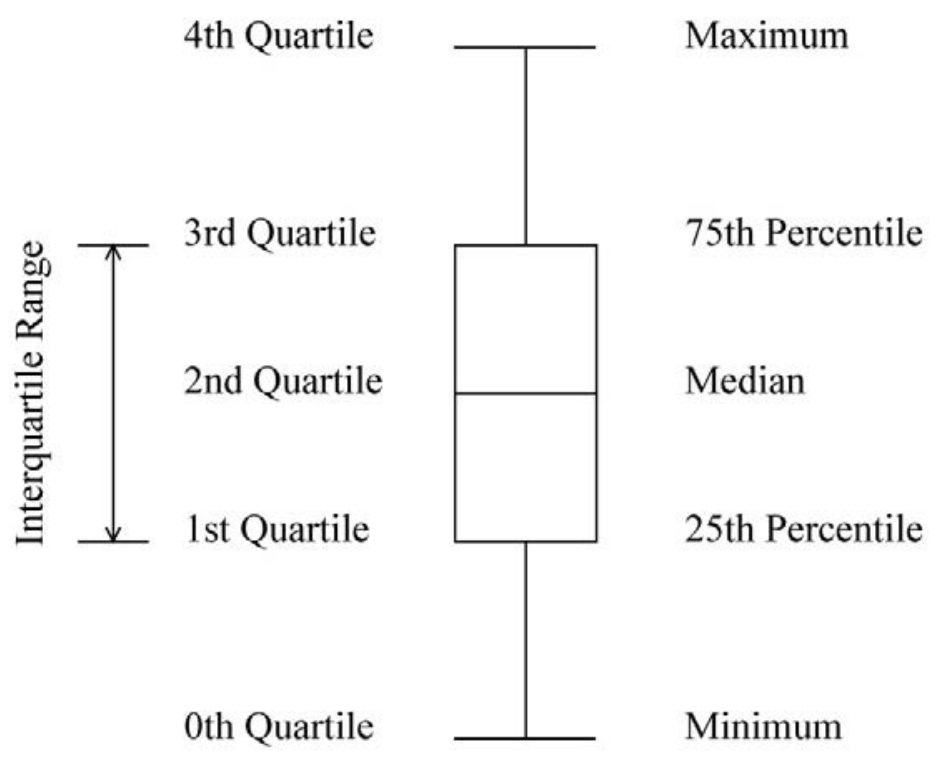

Figure 2. Diagram explaining a box and whisker diagram. 
North Santiam River below Boulder Creek near Detroit (North Santiam)
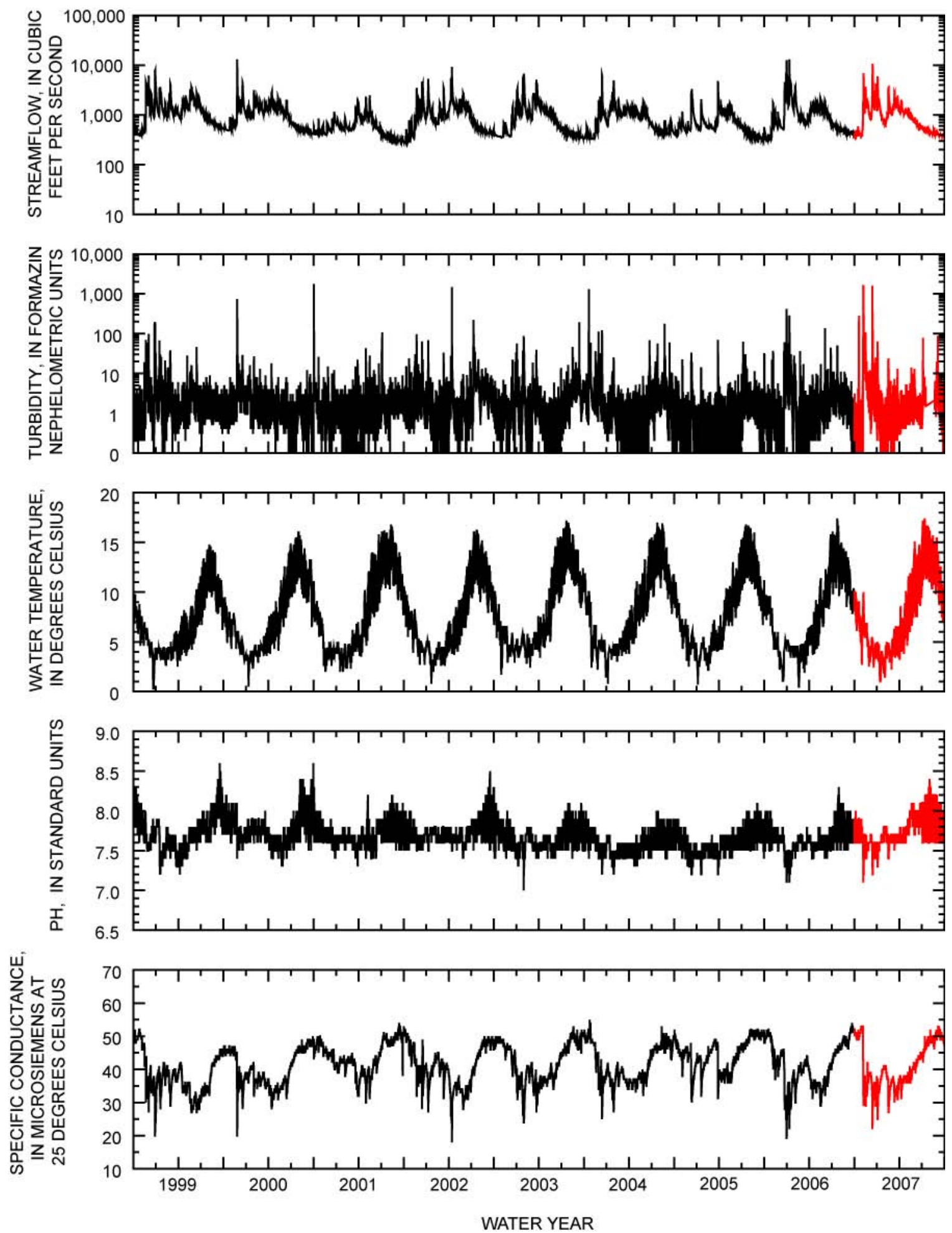

Figure 3. Graphs showing continuous values recorded at the North Santiam monitoring station, North Santiam River basin, Oregon, for the period of study. 

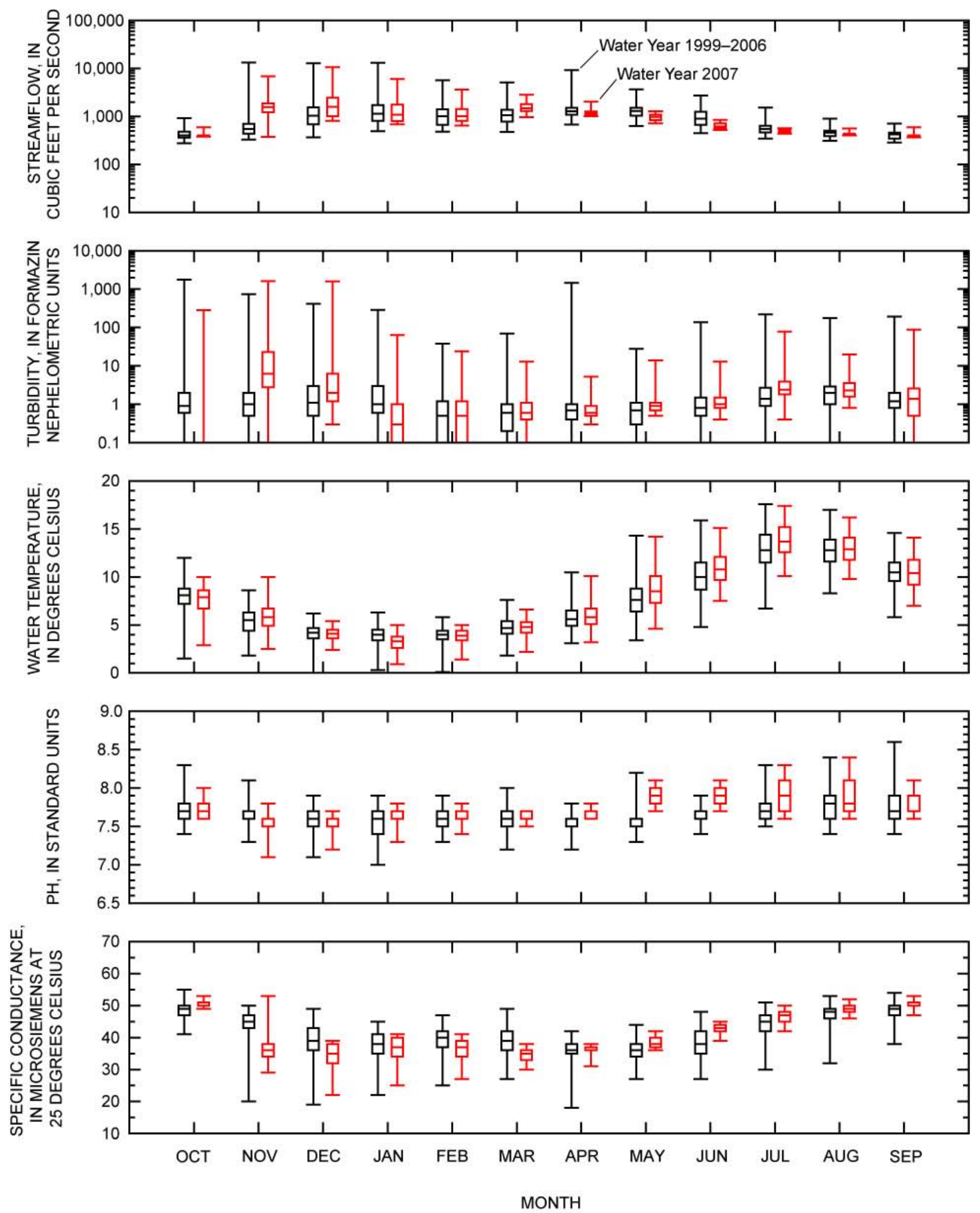

Figure 4. Graphs showing comparison of monthly water year 2007 streamflow, turbidity, water temperature, pH, and specific conductance to water year 1999-2006 values recorded at the North Santiam monitoring station, North Santiam River basin, Oregon. 


\section{Streamflow}

- $\quad$ Streamflow values at North Santiam in WY 2007 were similar to those of WY 1999-2006 streamflow data (fig. 3), indicating that, overall, WY 2007 streamflow characteristics were normal for the stream. Higher peak flows and lower minimum flows than occurred in WY 2007 were recorded during WY 1999-2006 (figs. 3, 4, and 5).

- Nonetheless, North Santiam recorded higher flows overall in November 2006 (WY 2007) than during any other November in the period of study (fig. 4). Three-quarters of streamflow values for November 2006 (WY 2007) were higher than three-quarters of WY 1999-2006 aggregated values as a result of a large storm in early November and other storms throughout the month.

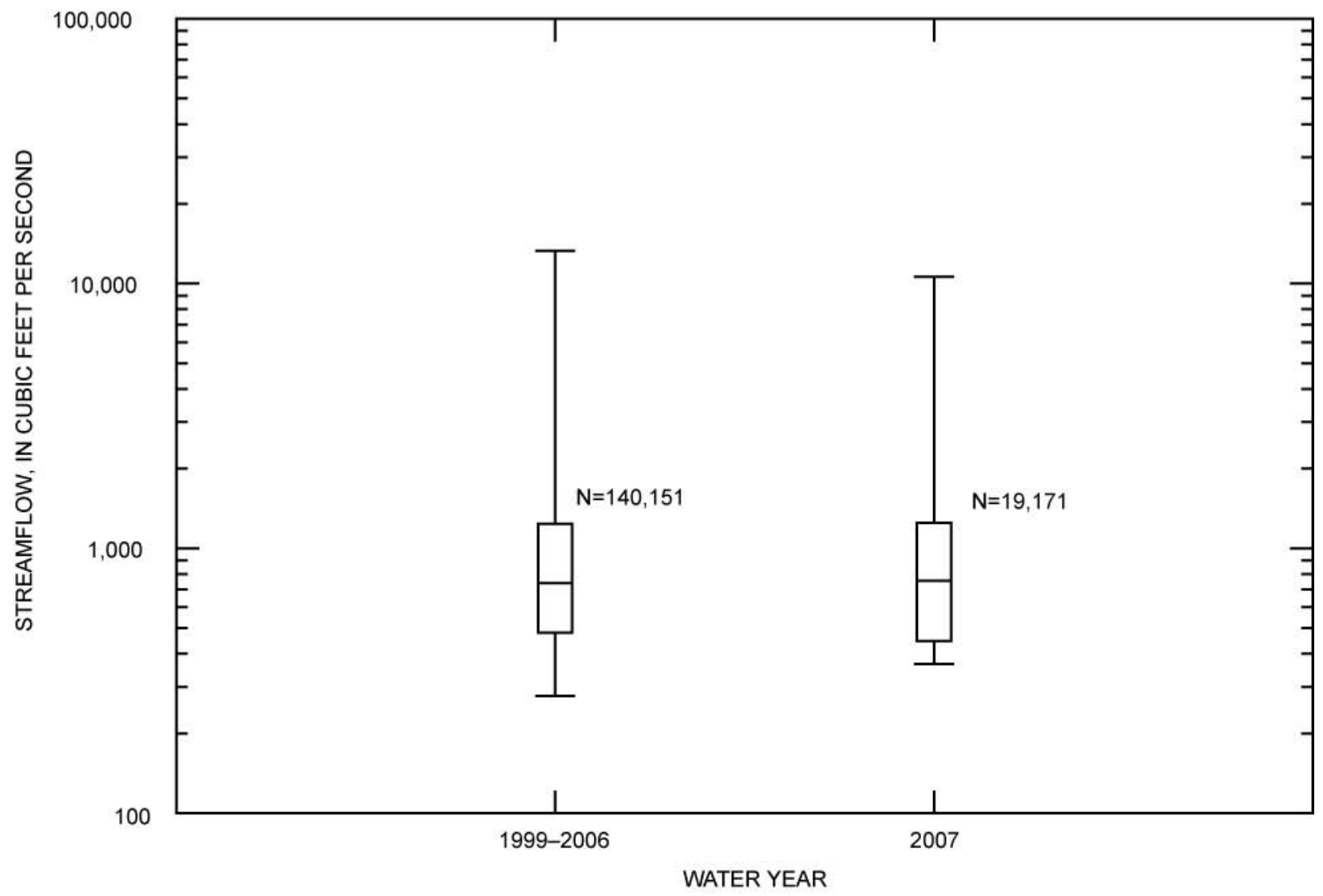

Figure 5. Graph showing comparison of water year 2007 streamflow data with combined data from water years 1999-2006 recorded at the North Santiam monitoring station, North Santiam River basin, Oregon. 


\section{Turbidity}

- Overall turbidity characteristics in the upper North Santiam River in WY 2007 were generally similar to those of past years (figs. 3, 4, and 6). However, values in November and December were generally higher than in past years (fig. 4). The most extreme turbidity values are not shown in the figures because the sensors cannot record values higher than 1,200 to 1,800 FNU, depending on the instrument. Values exceeded the sensor maximum on several occasions in November and December 2006.

- In early November of WY 2007, a debris flow in the upper basin (Sobieszczyk and others, 2008) increased turbidity and sediment load to a maximum for the period of study. Analysis of suspended sediment samples collected during the event resulted in an estimated peak turbidity of equal to or greater than 30,000 FNU (not shown in the figures). In several of the previous water years, the sensor reached its maximum threshold value for extended periods of an hour or more. Estimates of turbidity greater than the instrument capacity have been published in Bragg and others (2007) and Sobiesczcyk and others (2007).

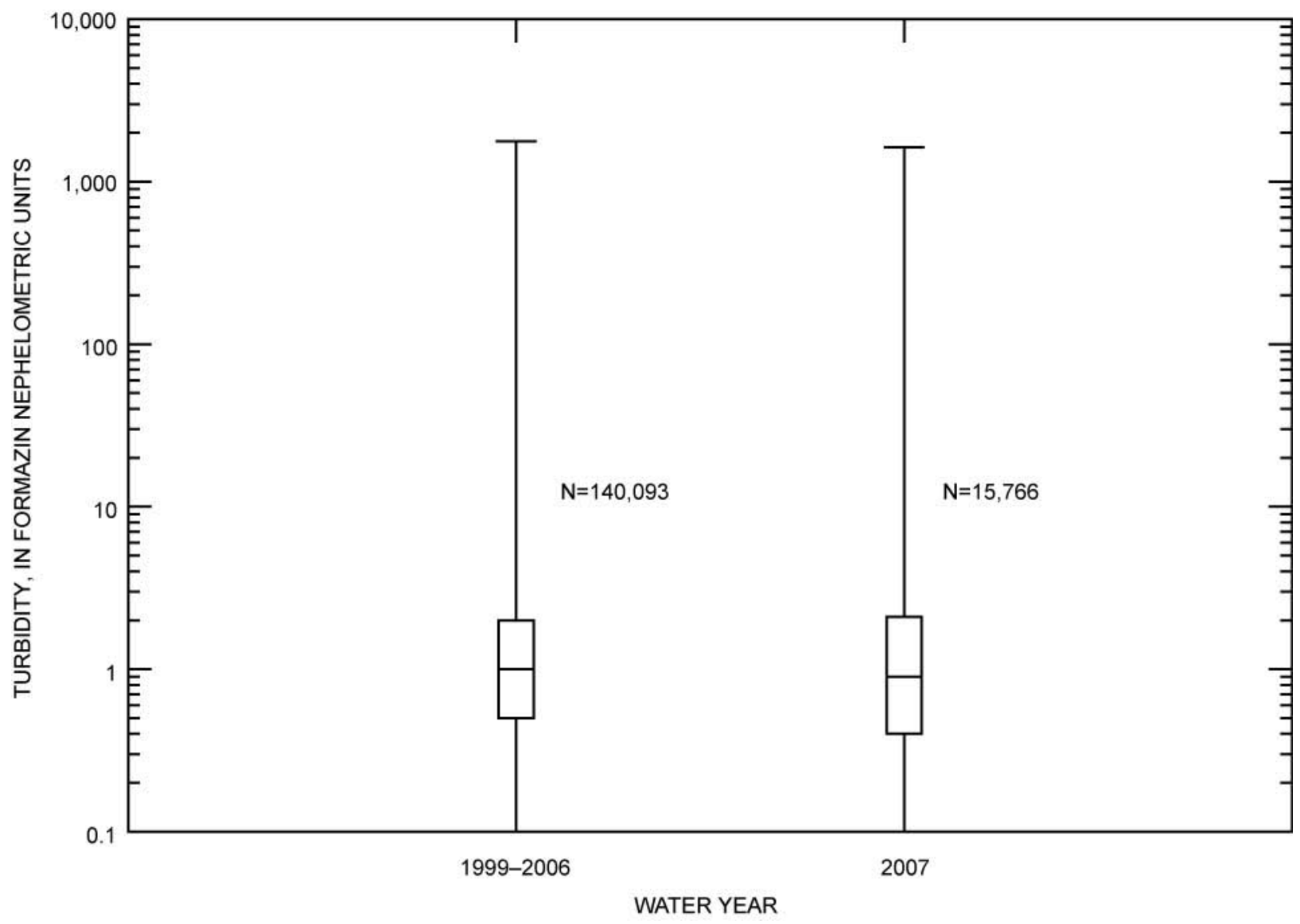

Figure 6. Graph showing comparison of water year 2007 turbidity data with combined data from water years 19992006 recorded at the North Santiam monitoring station, North Santiam River basin, Oregon. 


\section{Water Temperature}

- $\quad$ The range of water temperature in WY 2007 was similar to the range of water temperature in previous years (figs. 3, 4, and 7).

- November 2006 (WY 2007) had the warmest water temperature for this station of any November since WY 1999 (fig. 4), when the water-quality monitoring network began operation.

- January 2007 water temperatures were generally much lower than in the previous years of record (fig. 4).

- Maximum water temperatures at this station have not exceeded the State standard for Rearing and Migration habitat $\left(18^{\circ} \mathrm{C}\right)$ at any time during the period of record (fig. 7$)$.

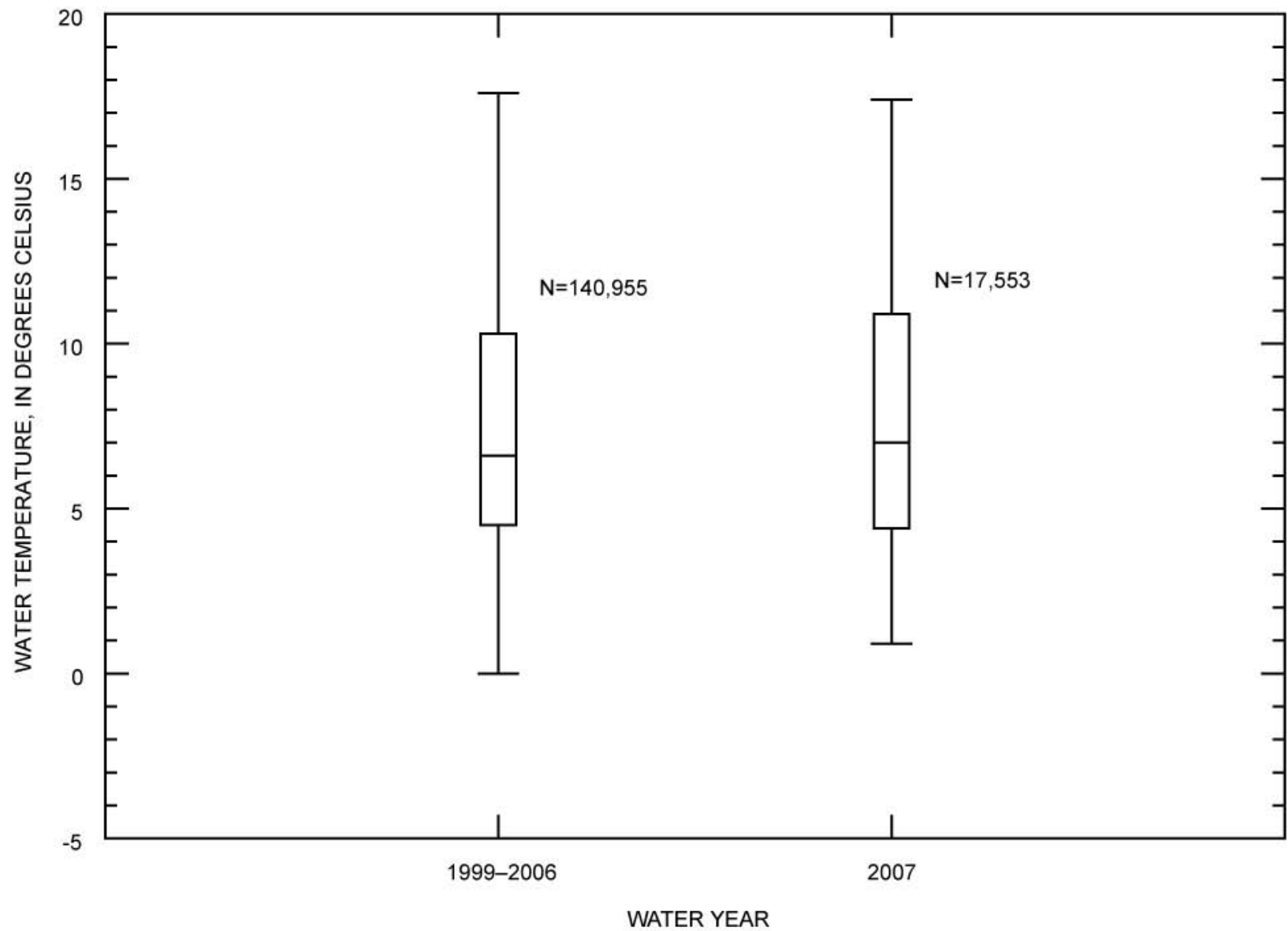

Figure 7. Graph showing comparison of water year 2007 water temperature data with combined data from water years 1999-2006 recorded at the North Santiam monitoring station, North Santiam River basin, Oregon. 
$\mathrm{pH}$

- $\quad$ HH values in WY 2007 were similar to those in the record prior to 2007 (fig. 3); however, there were higher and lower outlier values in the pre-WY 2007 period of study (figs. 4 and 8).

- Two values exceeded the maximum State standard in the pre-WY 2007 dataset, but no values exceeded the minimum State standard at this station during the period of record to WY 2007.

- $\quad$ Peak pH values for June 2007 were new maximums for the month, and peak values for April, July, and August 2007 were equal to maximum values in the pre-WY 2007 data set (fig. 4).

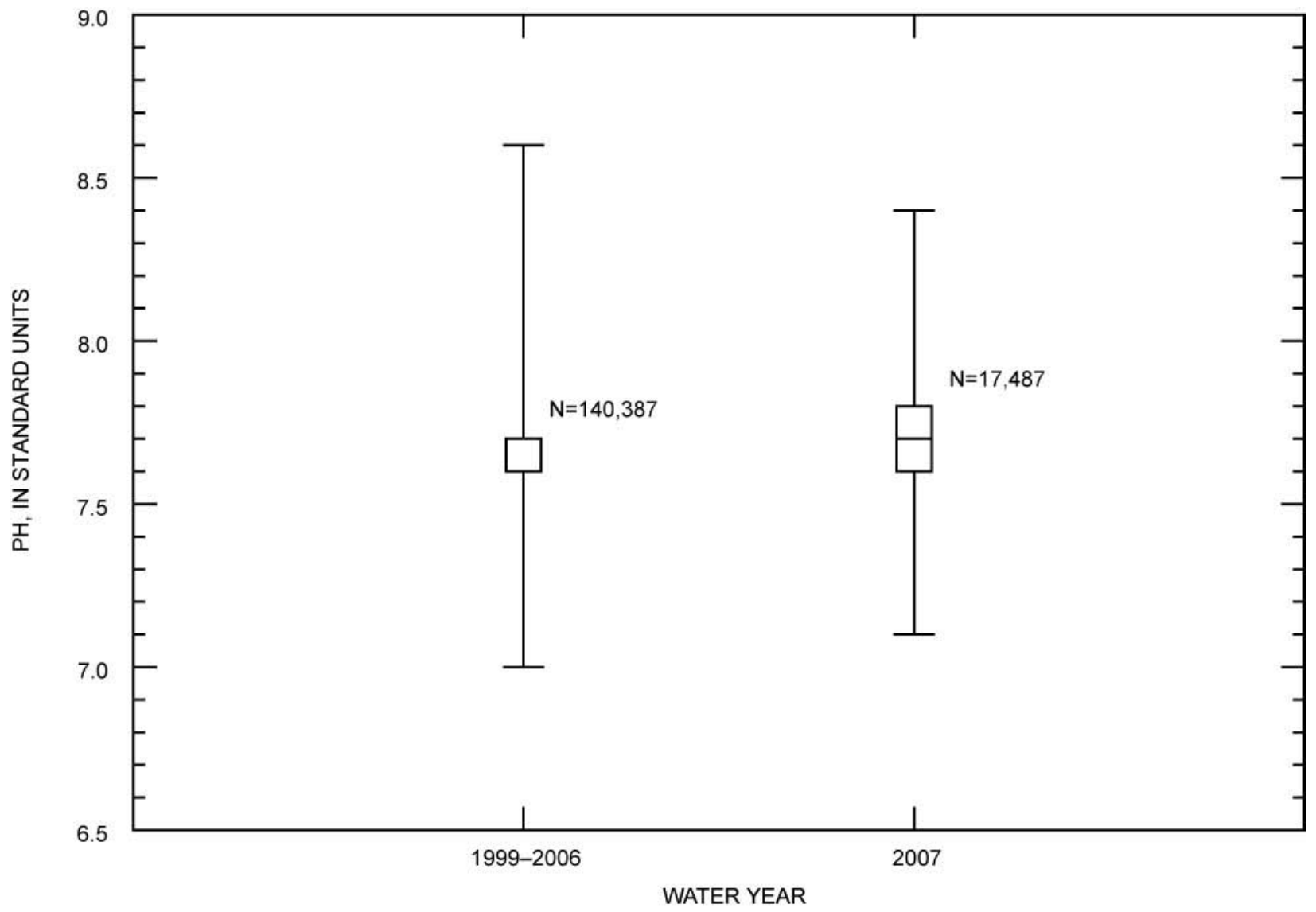

Figure 8. Graph showing comparison of water year 2007 pH data with combined data from water years 1999-2006 recorded at the North Santiam monitoring station, North Santiam River basin, Oregon. 


\section{Specific Conductance}

- $\quad$ Specific conductance values in WY 2007 were similar to those of previous water years (figs. 3 and 4); however; the middle 50 percent of the data had a greater range in WY 2007 than in combined previous water years (fig. 9), indicating generally higher variability in WY 2007 specific conductance.

- $\quad$ Values exceeded the $50 \mu \mathrm{S} / \mathrm{cm}$ threshold value in WY 2007 more than in prior years: about 9.6 percent compared with 3.7 percent.

- Specific conductance values in WY 2007 were generally lower in winter and early spring than in previous years, whereas in summer they were higher (fig. 4).

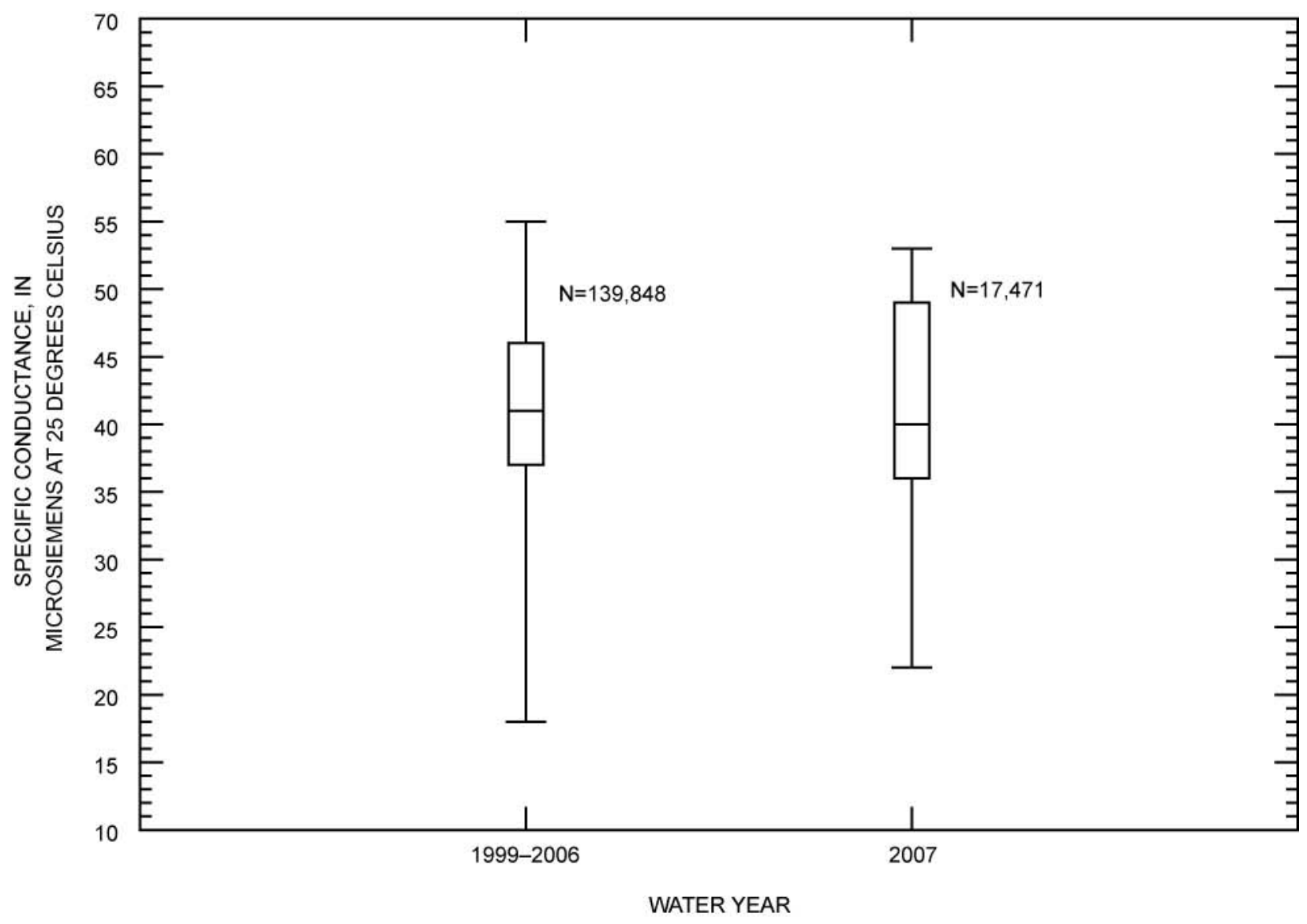

Figure 9. Graph showing comparison of water year 2007 specific conductance data with combined data from water years 1999-2006 recorded at the North Santiam monitoring station, North Santiam River basin, Oregon. 
Breitenbush River above French Creek near Detroit (Breitenbush)
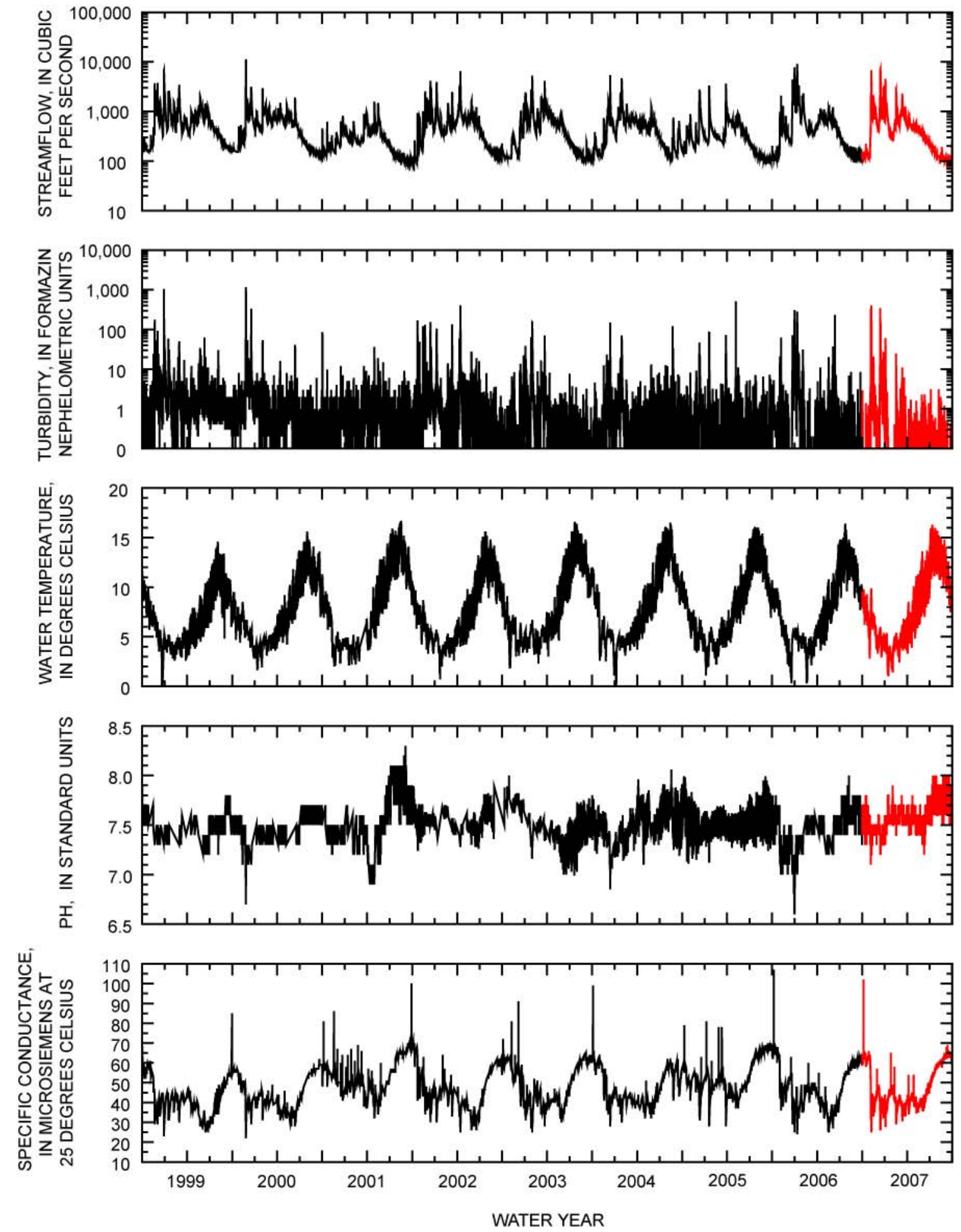

Figure 10. Graphs showing continuous values recorded at the Breitenbush monitoring station, North Santiam River basin, Oregon, for the period of study. 

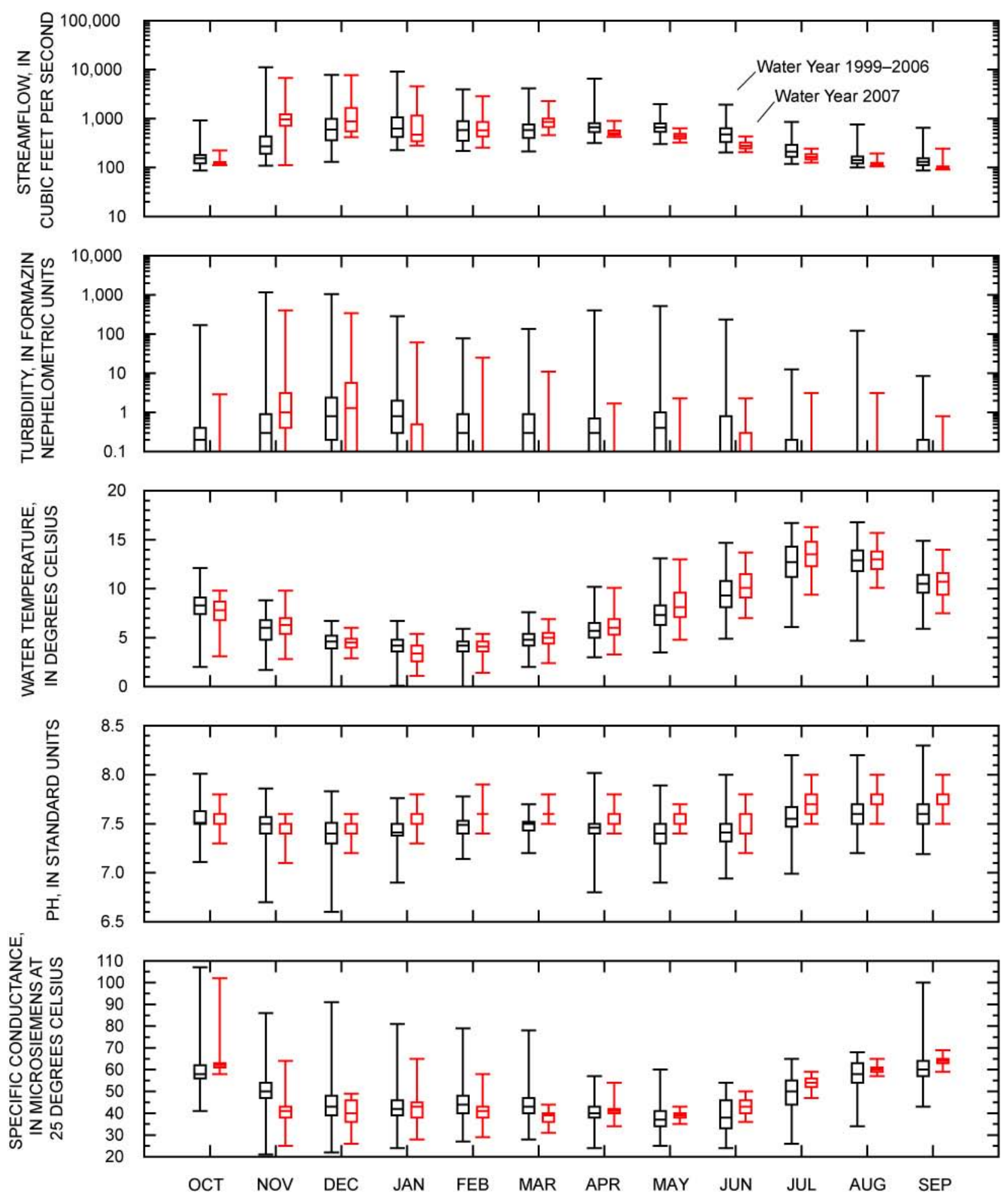

MONTH

Figure 11. Graphs showing comparison of monthly water year 2007 streamflow, turbidity, water temperature, pH, and specific conductance to water year 1999-2006 values recorded at the Breitenbush monitoring station, North Santiam River basin, Oregon 


\section{Streamflow}

- Streamflow at Breitenbush in WY 2007 was similar to that during WY 1999-2006 (figs. 10 and 11 ), although values in the 25 percent of flows less than the median were somewhat lower in WY 2007 (fig. 12), reflecting generally lower spring and summer flows in that year.

- Streamflow in November and December was much higher than normal (fig. 11).

- Summer streamflows were much lower than normal (fig. 11). The minimum streamflow in June equaled the period-of-study minimum for that month.

- Very low flows (less than p5) were more common in WY 2007 than in the previous period of study: 15.8 percent in WY 2007 and 5.9 percent in WY 1999-2006.

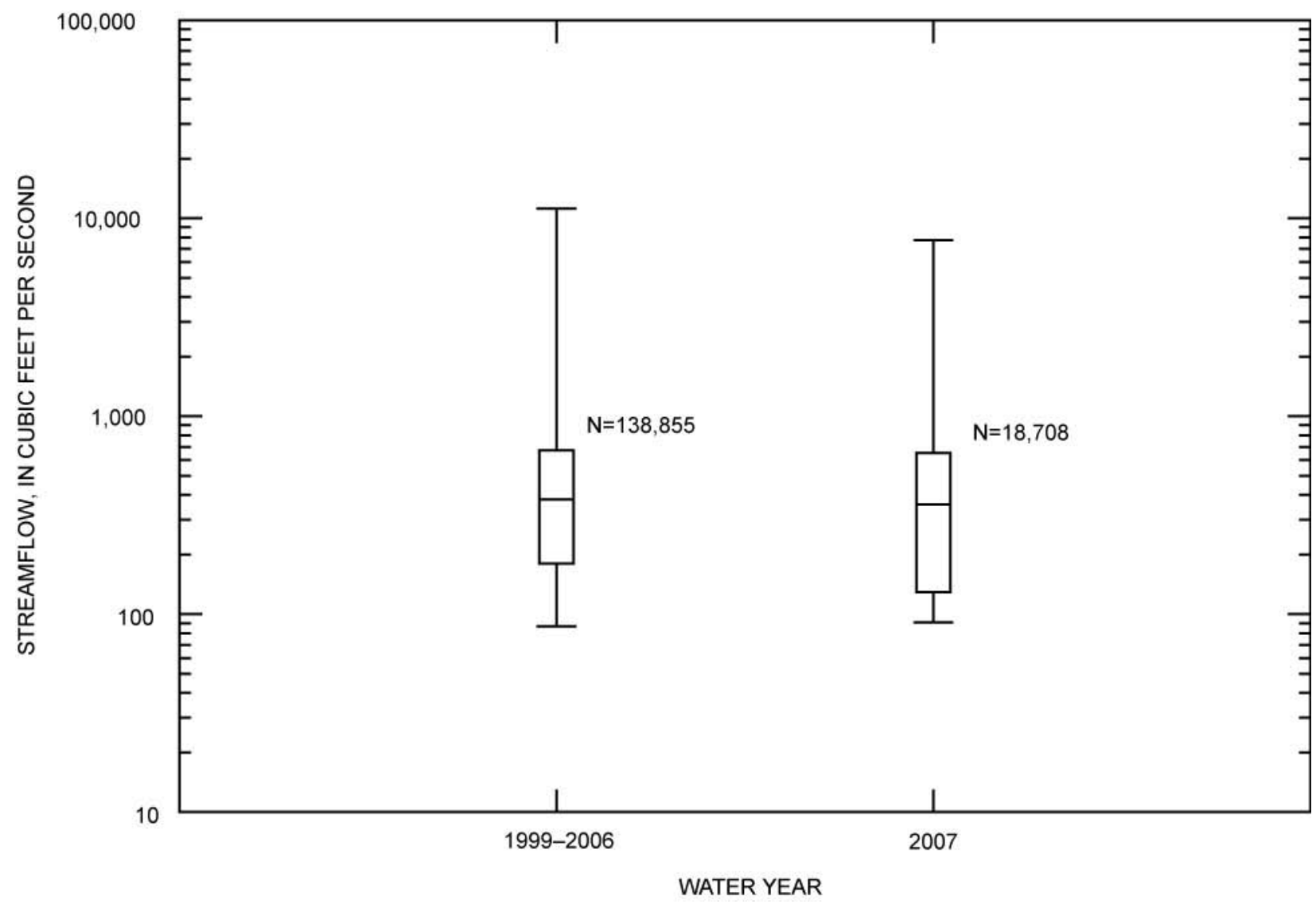

Figure 12. Graph showing comparison of water year 2007 streamflow data with combined data from water years 1999-2006 recorded at the Breitenbush monitoring station, North Santiam River basin, Oregon. 


\section{Turbidity}

- Turbidity was generally less in WY 2007 than in previous years (figs. 10, 11, and 13). Turbidity at the site is typically less than $1 \mathrm{FNU}$, less than can be reliably measured.

- Turbidity was generally greater in November and December of WY 2007 than in previous years of study (fig. 11); however no new peak turbidity was recorded, and greater than 75 percent of values were less than $10 \mathrm{FNU}$ during both months.

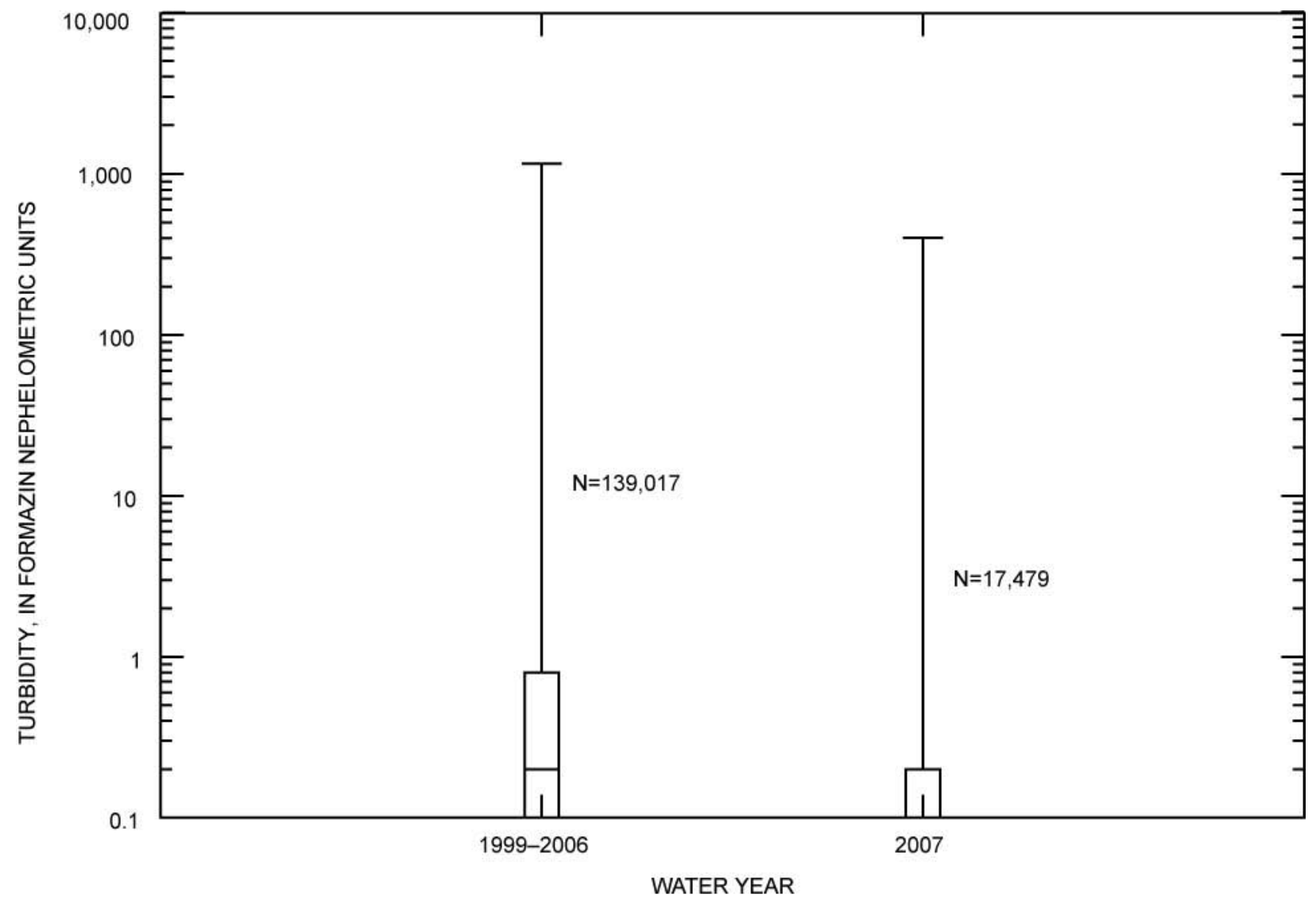

Figure 13. Graph showing comparison of water year 2007 turbidity data with combined data from water years 1999-2006 recorded at the Breitenbush monitoring station, North Santiam River basin, Oregon. 


\section{Water Temperature}

- Stream temperatures were generally similar between WY 2007 and previous years (figs. 10, 11, and 14)

- Stream temperature in January 2007 was cooler on average than in past Januarys during the period of study; 75 percent of January 2007 water temperatures were equal to or less than the aggregated 1999-2006 median value for the month (fig. 11).

- A new monthly maximum temperature value of $9.8^{\circ} \mathrm{C}$ was established in November 2006 (fig. 11).

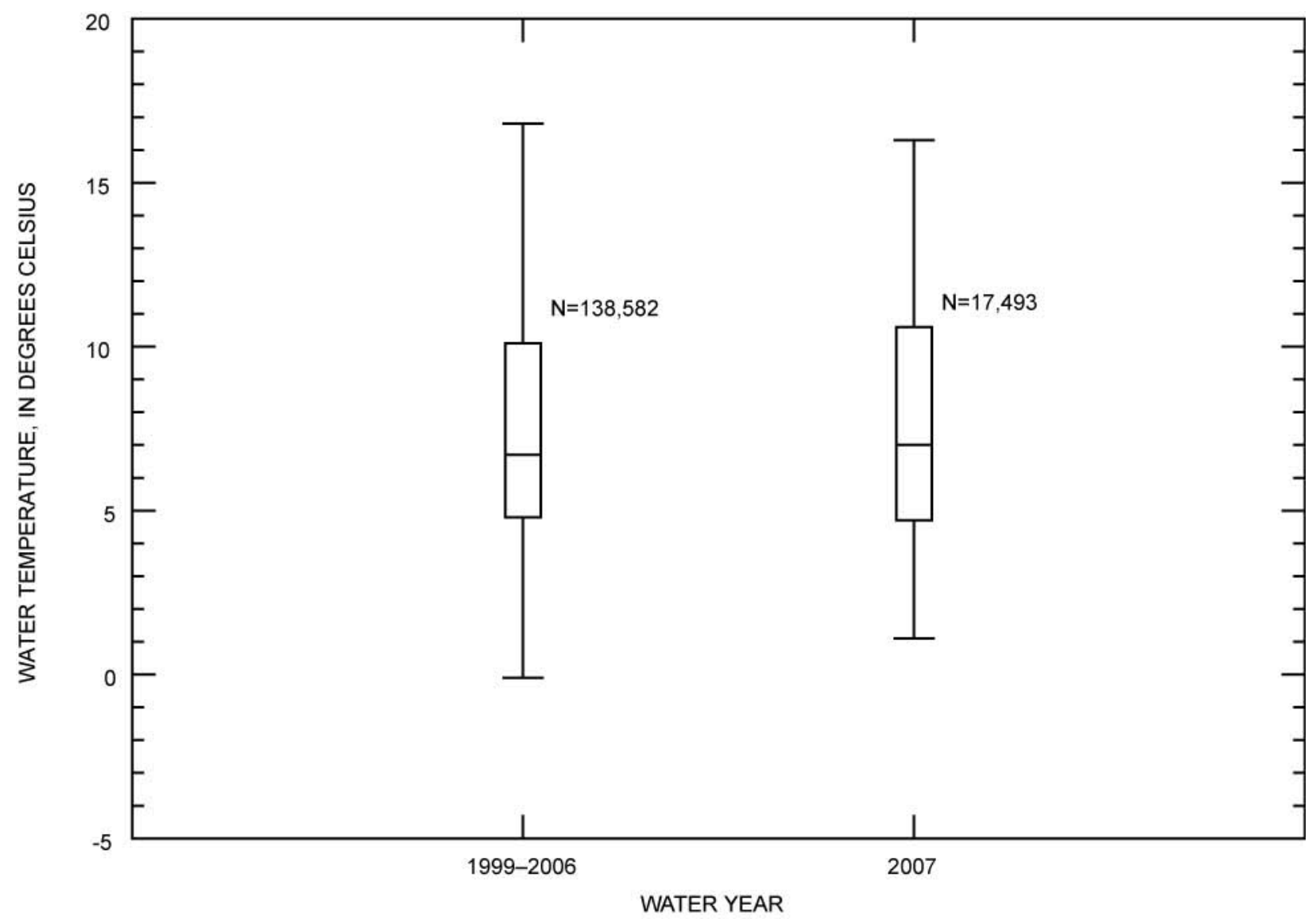

Figure 14. Graph showing comparison of water year 2007 water temperature data with combined data from water years 1999-2006 recorded at the Breitenbush monitoring station, North Santiam River basin, Oregon. 
$\mathrm{pH}$

- $\mathrm{pH}$ values in WY 2007 were similar to or slightly higher than in prior years (figs. 10, 11, and 15).

- $\quad$ The range of values in WY 2007 was narrower than that of the combined prior water years (fig. 15), indicating a lack of extreme values in WY 2007.

- Nonetheless, new monthly peak pH values were recorded in January, February, and March 2007 (fig. 11).

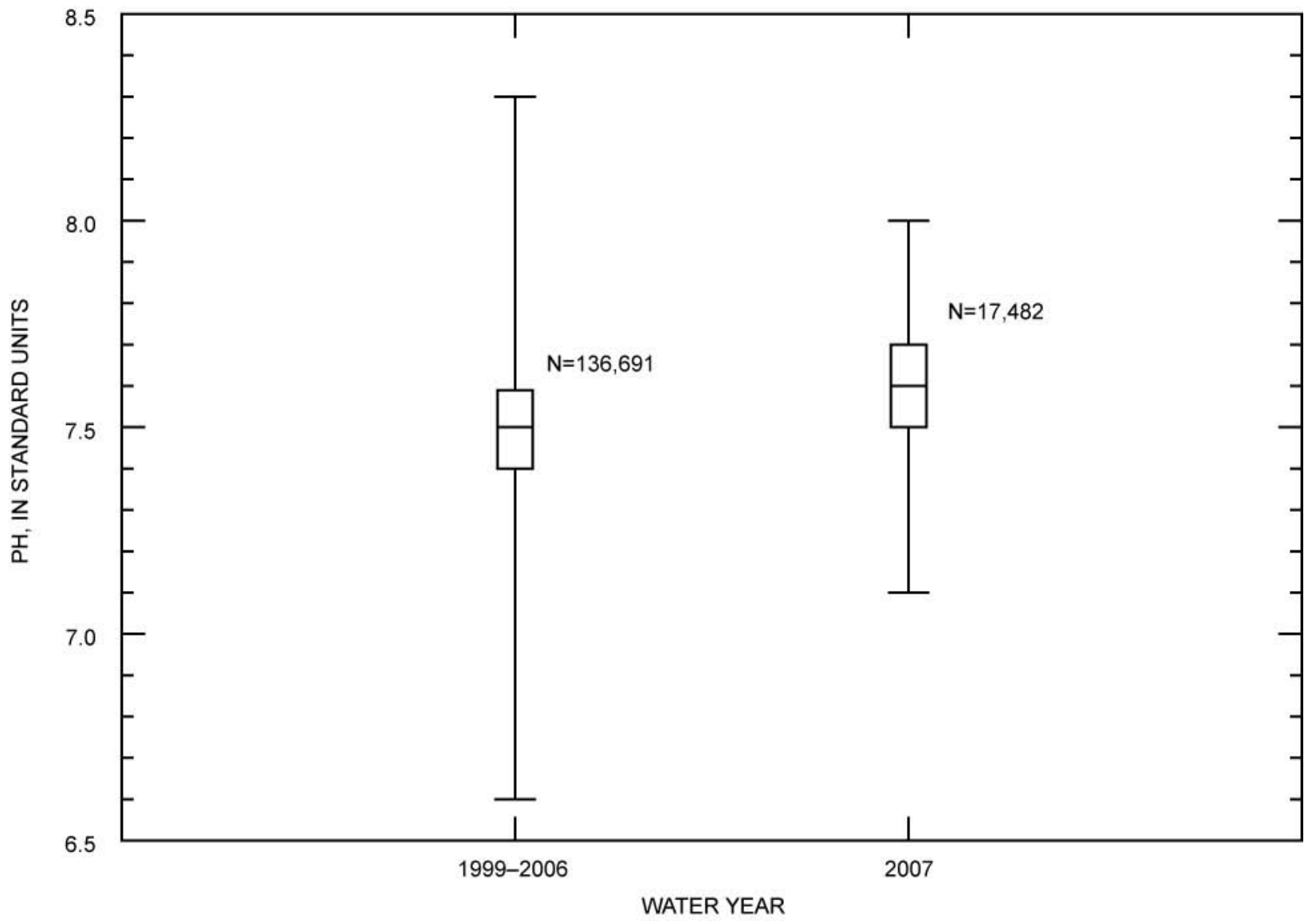

Figure 15. Graph showing comparison of water year 2007 pH data with combined data from water years 19992006 recorded at the Breitenbush monitoring station, North Santiam River basin, Oregon. 


\section{Specific Conductance}

- Specific conductance at Breitenbush in WY 2007 was generally similar to that of previous years (figs. 10, 11, and 16).

- About one-third of the specific conductance values in the WY 2007 and previous period of study were greater than $50 \mu \mathrm{S} / \mathrm{cm}$ (fig. 16).

- In November 2006, more than 75 percent of the data were less than the water year 1999-2006 25th percentile for the month.

- Primarily during the fall and winter, short duration spikes appear in the specific conductance data (fig. 10). These are real increases, but the source(s) of the spikes have not been determined.

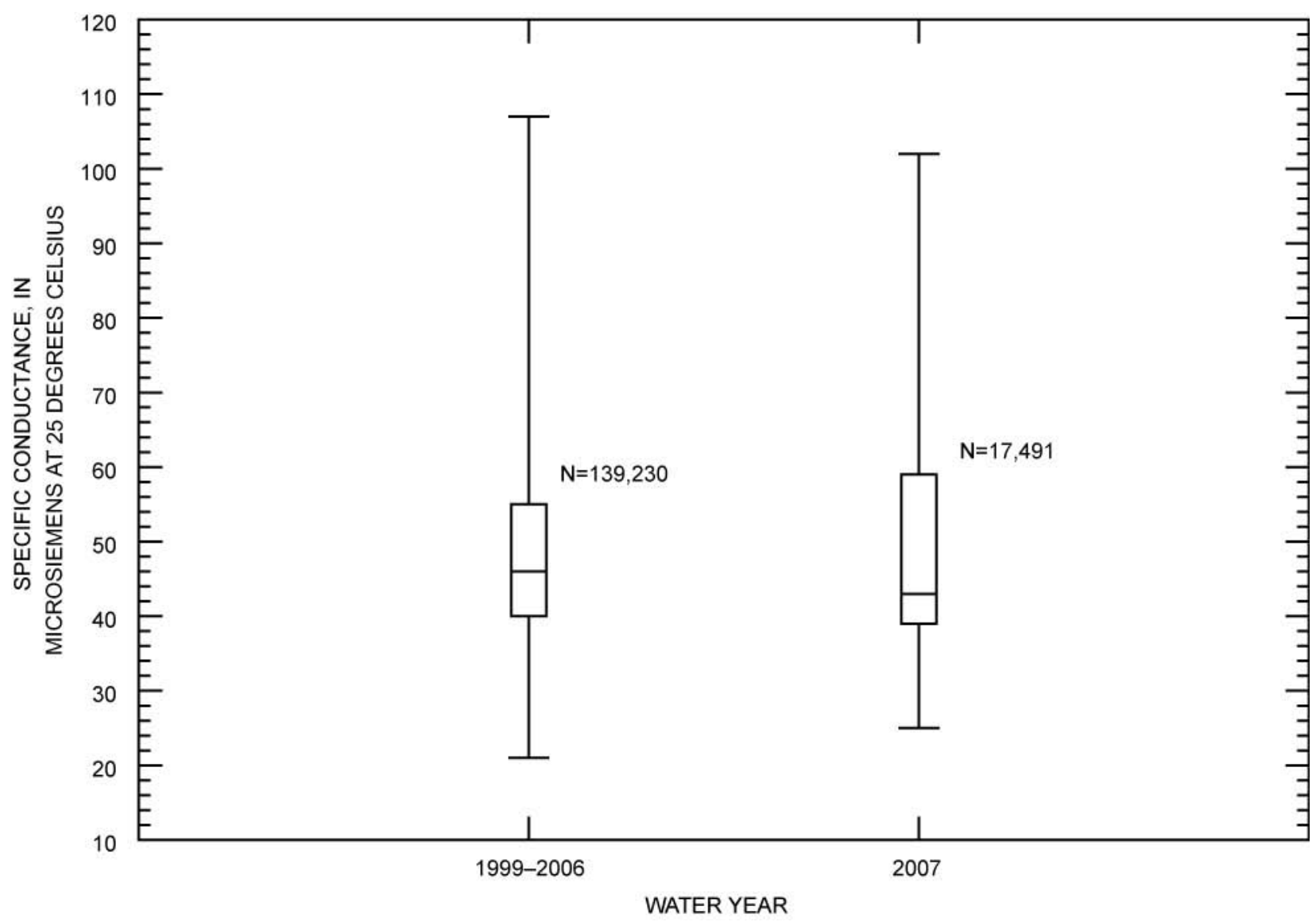

Figure 16. Graph showing comparison of water year 2007 specific conductance data with combined data from water years 1999-2006 recorded at the Breitenbush monitoring station, North Santiam River basin, Oregon. 


\section{French Creek near Detroit}

The French Creek streamflow gaging station was originally located about 1.5 miles northwest of the town of Detroit, Oregon, at the intersection of French Creek and NFD 2225 roads. The station was

moved about $600 \mathrm{ft}$ downriver in August 2005. Collection of water-quality data began in October 2001 (except water temperature, which began in July 2001), and was discontinued in December 2005 because of funding constraints. No data comparisons for WY 2007 are available because of discontinuation of the station in 2005. Figure 17 presents monthly data for the period of record. 

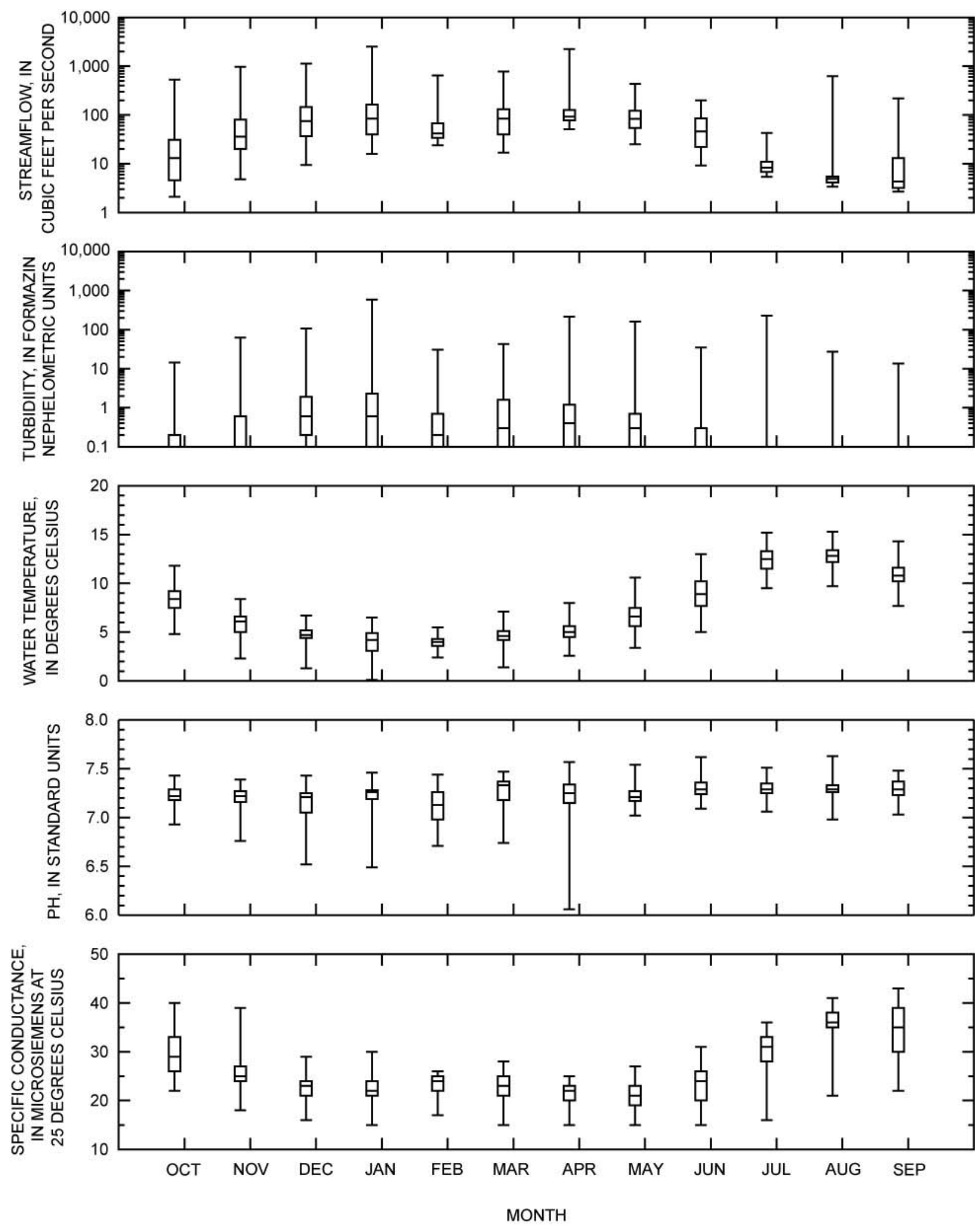

Figure 17. Graphs showing combined monthly streamflow, turbidity, water temperature, $\mathrm{pH}$, and specific conductance values for water years 2002-05 recorded at the French monitoring station, North Santiam River basin, Oregon. Water temperature monitoring began in July 2001. 
Blowout Creek near Detroit (Blowout)
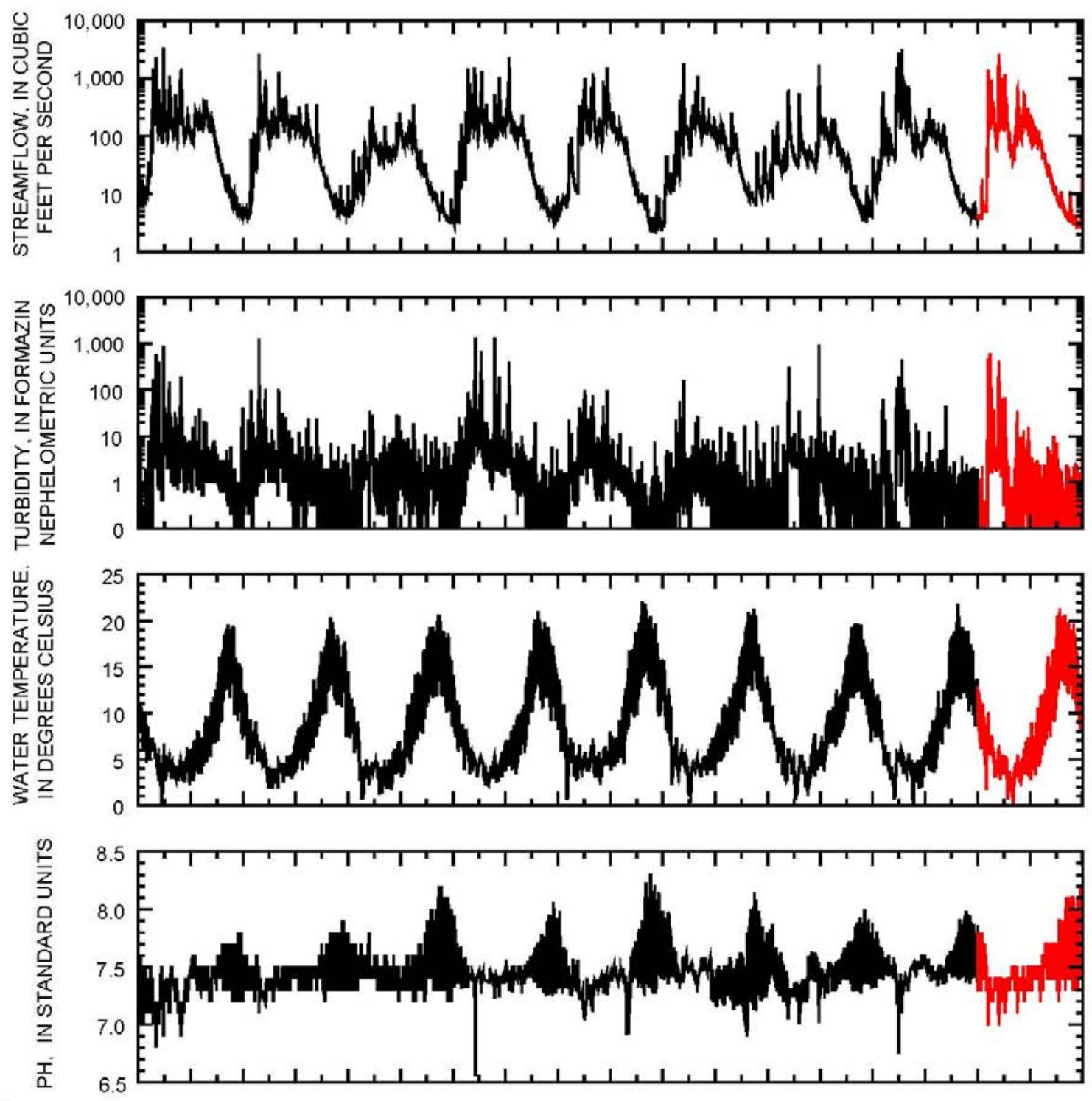

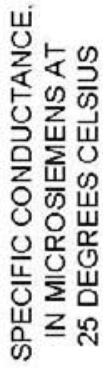

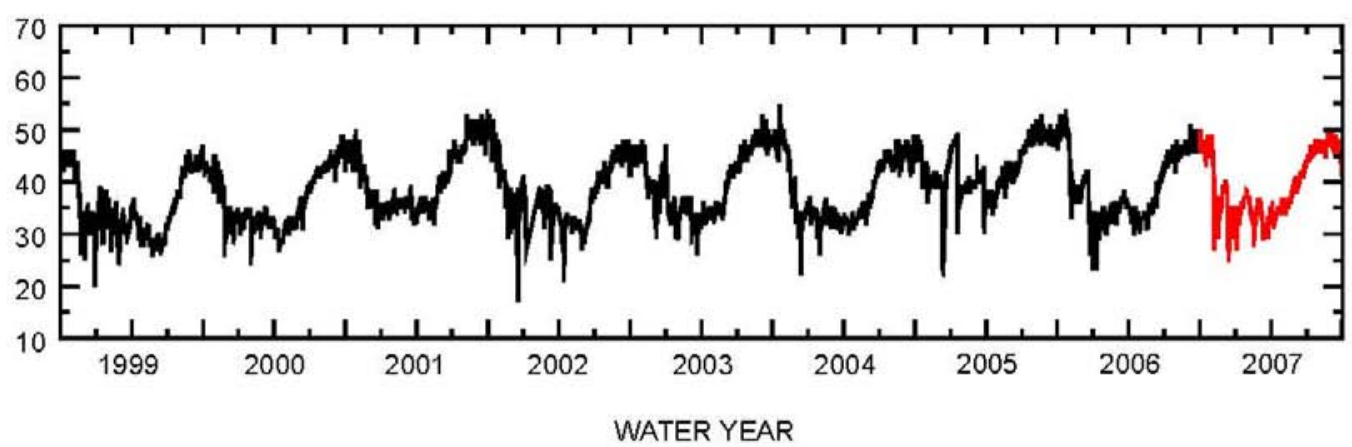

Figure 18. Graphs showing continuous values recorded at the Blowout monitoring station, North Santiam River basin, Oregon, for the period of record. 

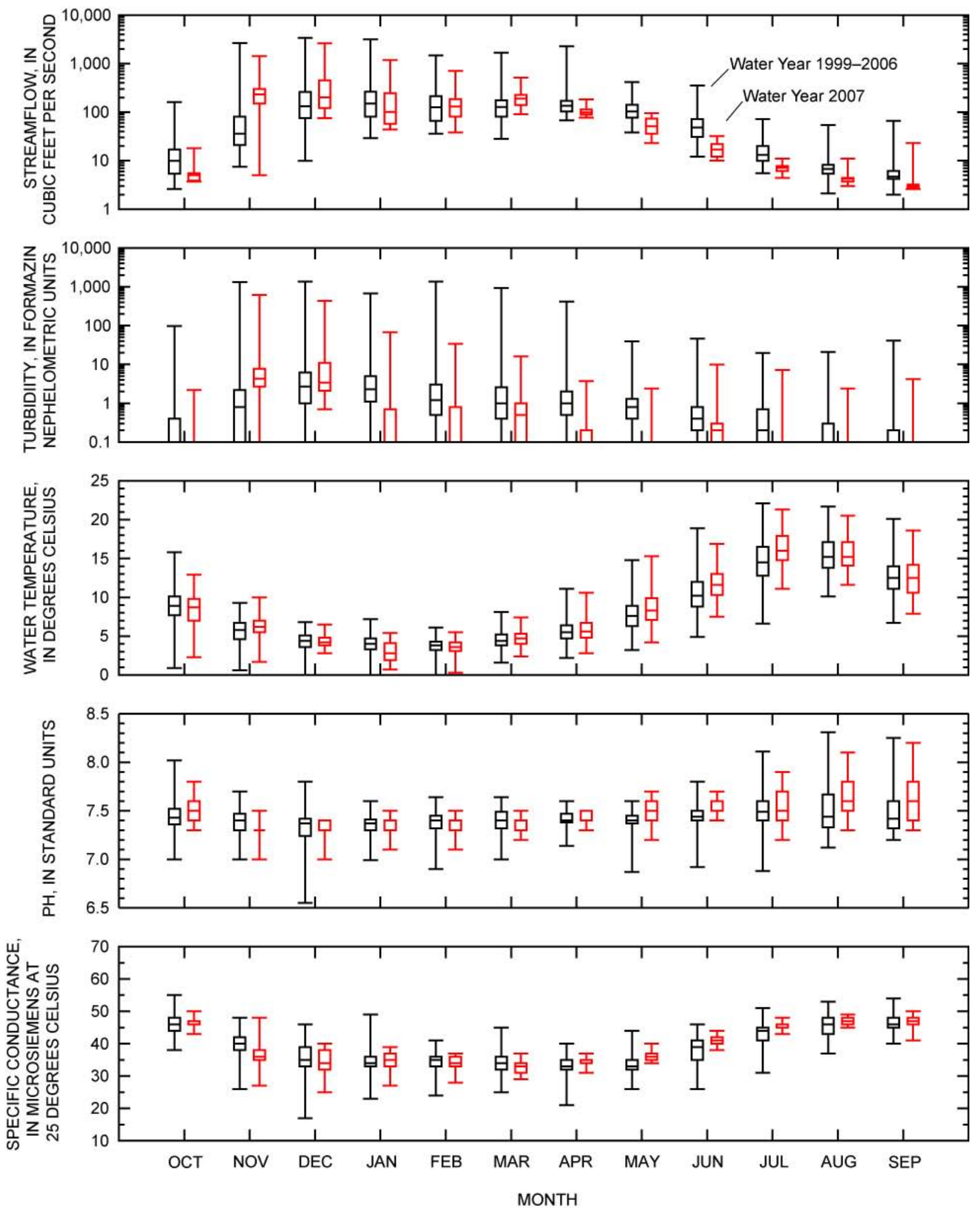

Figure 19. Graphs showing comparison of monthly water year 2007 streamflow, turbidity, water temperature, $\mathrm{pH}$, and specific conductance to water year 1999-2006 values recorded at the Blowout monitoring station, North Santiam River basin, Oregon 


\section{Streamflow}

- Streamflow at Blowout in WY 2007 was similar to that in WY 1999-2006 (figs. 18 and 19), although values in 25 percent of flows less than the median were somewhat lower in WY 2007 (fig. 20), reflecting generally lower spring and summer flows in that year (fig. 19). No new yearly maximum or minimum streamflow was recorded in WY 2007.

- During November 2006 (WY 2007), a very wet month, more than 75 percent of streamflows were greater than the 75th percentile of WY 1999-2006 data, and in March, 75 percent were greater than the WY 1999-2006 median (fig. 19).

- Very low flows (less than p5) were more common in WY 2007 than in the previous period of study: 17 percent in WY 2007 and 4.8 percent in prior years.

- New period of study monthly minimum streamflows were established at this station for WY 2007 in November and May-July (fig. 19).

- From May through July, values in the entire WY 2007 dataset were less than the WY 1999-2006 medians for the same months (fig. 19).

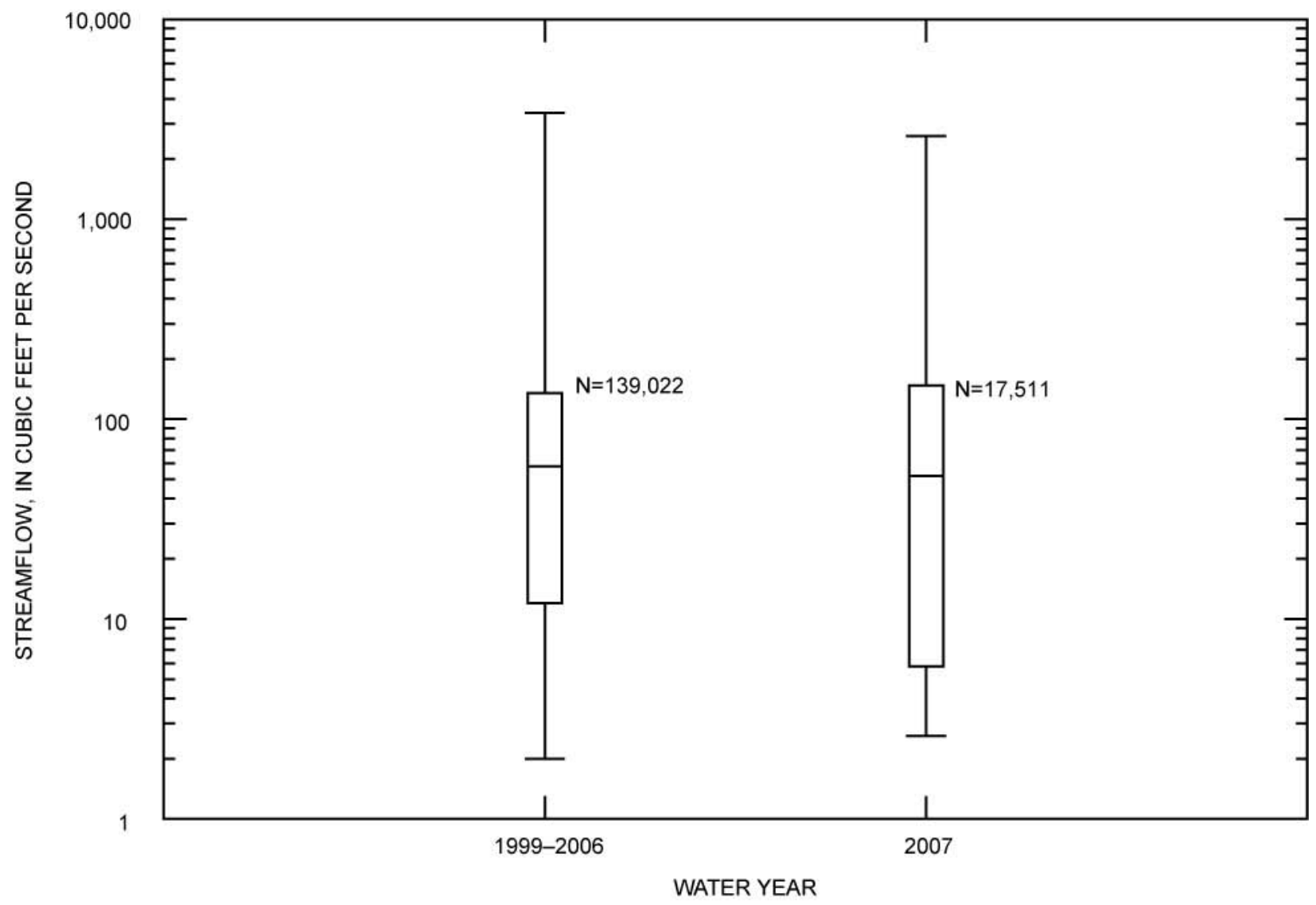

Figure 20. Graph showing comparison of water year 2007 streamflow data with combined data from water years 1999-2006 recorded at the Blowout monitoring station, North Santiam River basin, Oregon. 


\section{Turbidity}

- Turbidity was generally lower at Blowout in WY 2007 than in previous years; turbidity at this site is generally low, typically less than 1 FNU (figs. 18, 19, and 21).

- November 2006 was a high turbidity month; 75 percent of WY 2007 data were greater than 75 percent of WY 1999-2006 November data (fig. 19).

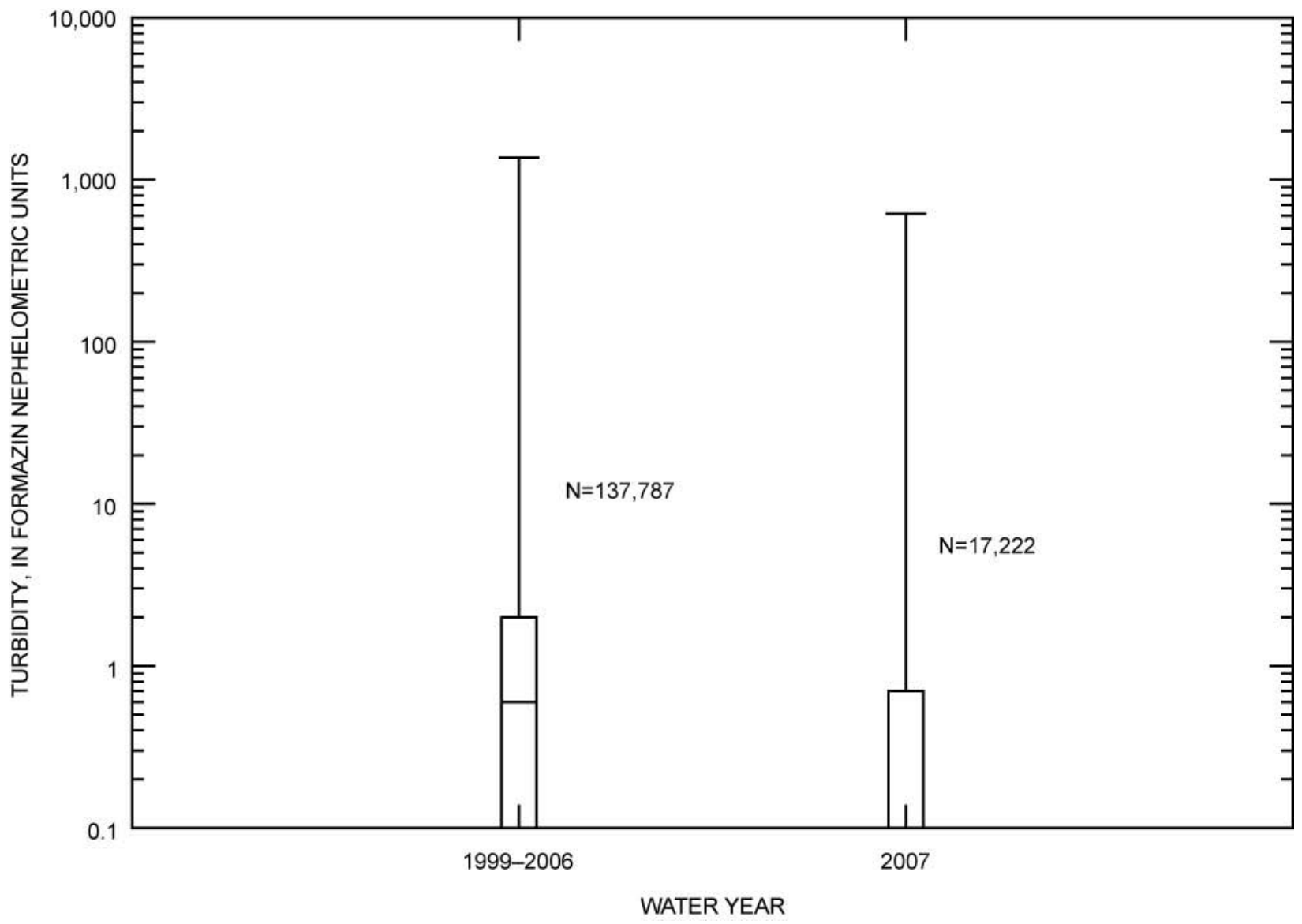

Figure 21. Graph showing comparison of water year 2007 turbidity data with combined data from water years 1999-2006 recorded at the Blowout monitoring station, North Santiam River basin, Oregon. 


\section{Water Temperature}

- Water temperature was similar in WY 2007 at Blowout to that during 1999-2006 (figs. 18, 19, and 22).

- The $18^{\circ} \mathrm{C}$ Rearing and Migration standard was exceeded in WY 2007 during July, August, and September (fig. 19). In June-September of the 1999-2006 data, at least one value exceeded the standard in each month.

- Peak water temperature in November of WY 2007 was greater than the peak temperature in years prior to WY 2007.

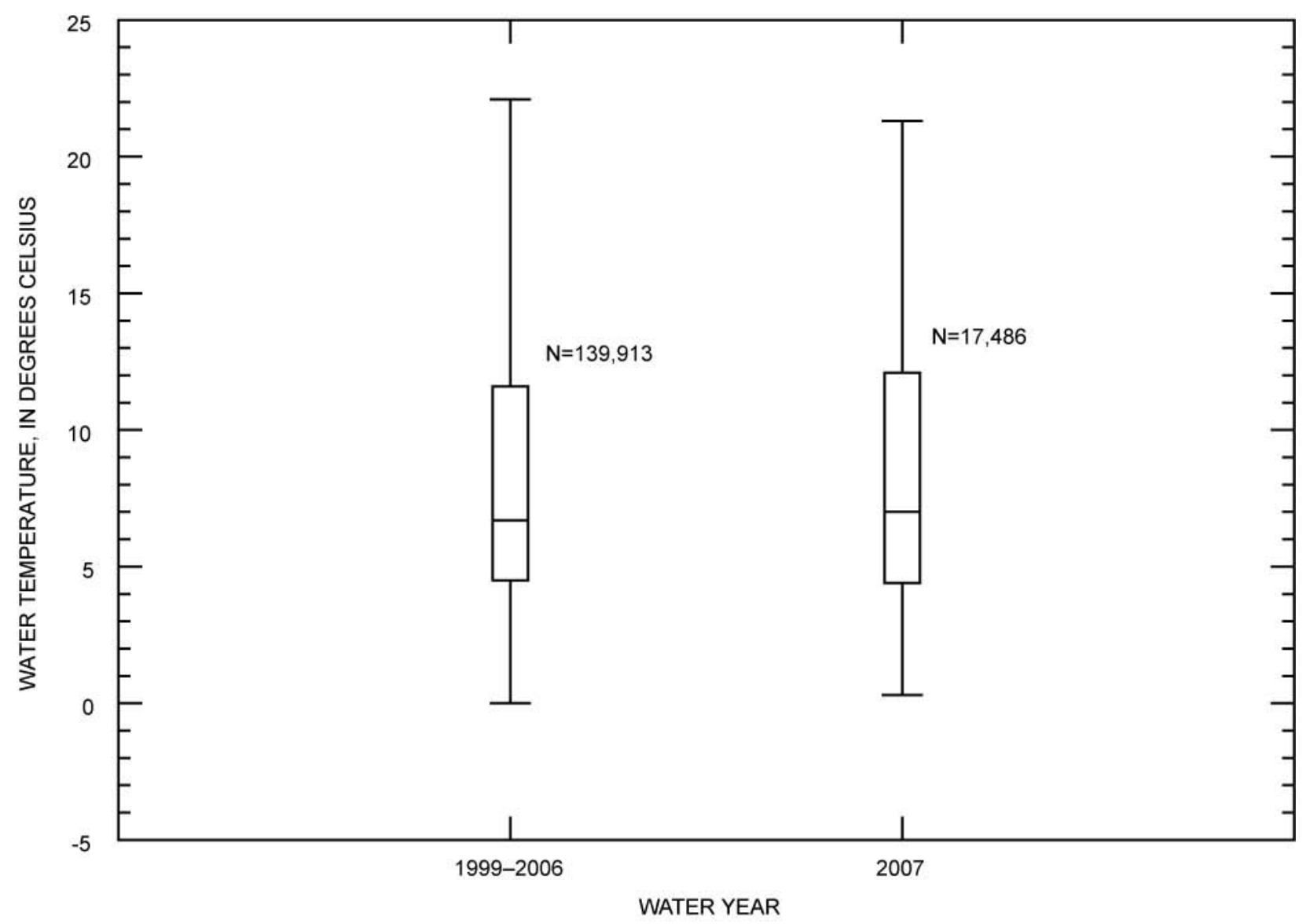

Figure 22. Graph showing comparison of water year 2007 water temperature data with combined data from water years 1999-2006 recorded at the Blowout monitoring station, North Santiam River basin, Oregon. 
$\mathrm{pH}$

- Overall pH values at Blowout in WY 2007 were similar to WY 1999-2006 values. No new annual maximum or minimum values were recorded (figs. 18, 19, and 23).

- A new monthly maximum pH value was established in May 2007 (fig. 19).

- Summer pH was generally higher in WY 2007 than in previous years (figs. 18 and 19).

- The pre-WY 2007 monthly minimum pH value was equaled in November 2006, during which $\mathrm{pH}$ was particularly low (fig. 19).

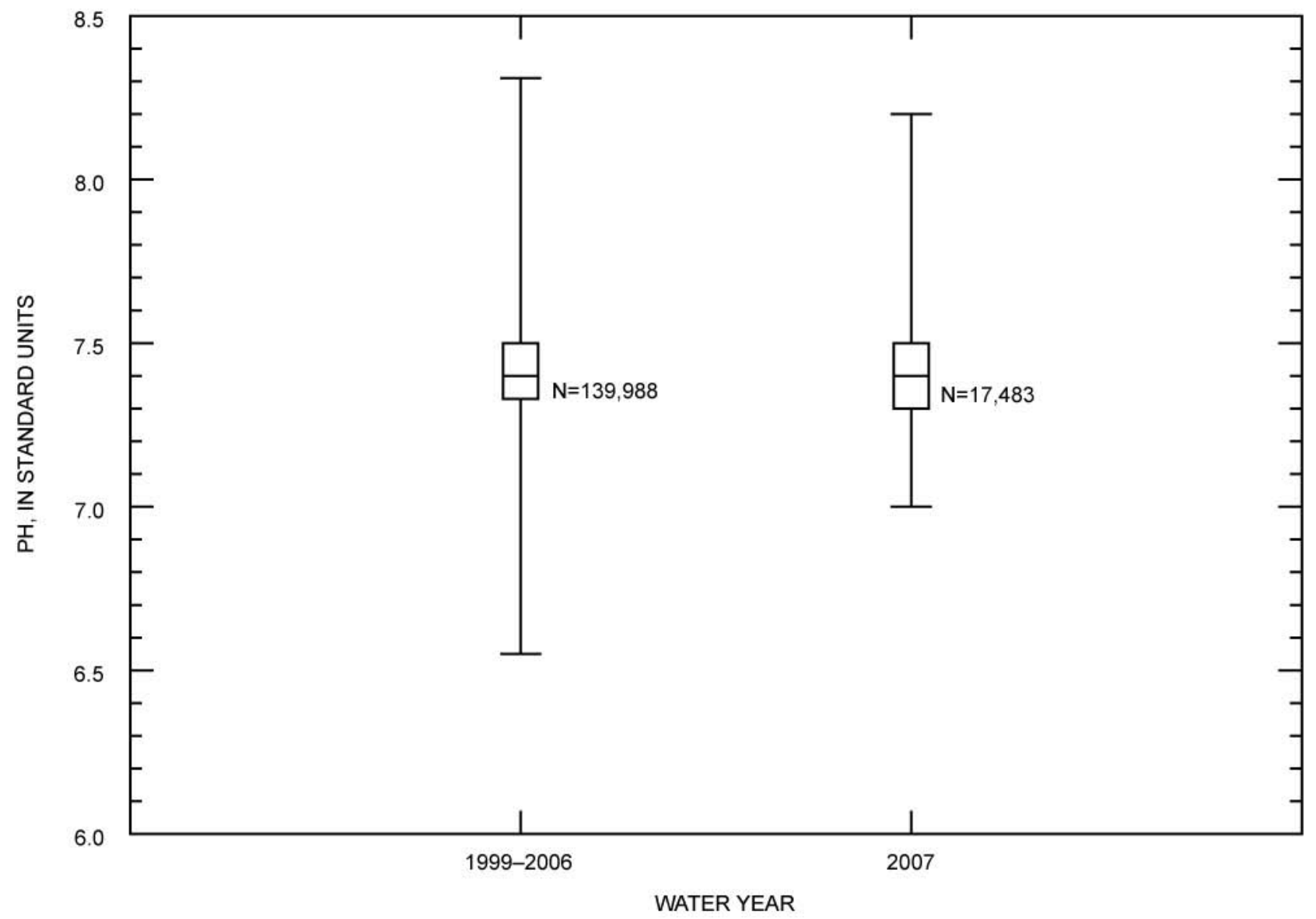

Figure 23. Graph showing comparison of water year 2007 pH data with combined data from water years 19992006 recorded at the Blowout monitoring station, North Santiam River basin, Oregon. 


\section{Specific Conductance}

- Specific conductance at Blowout in WY 2007 was generally similar to that of previous years (figs.18 and 19), but the range was narrower (fig. 24).

- Specific conductance values in WY 2007 were lower in winter and early spring than in previous years, but higher in summer (fig. 19); the differences, however, were slight.

- $\quad$ No new annual maximum or minimum conductance values were recorded in WY 2007; however, monthly maximum values were equaled during November.

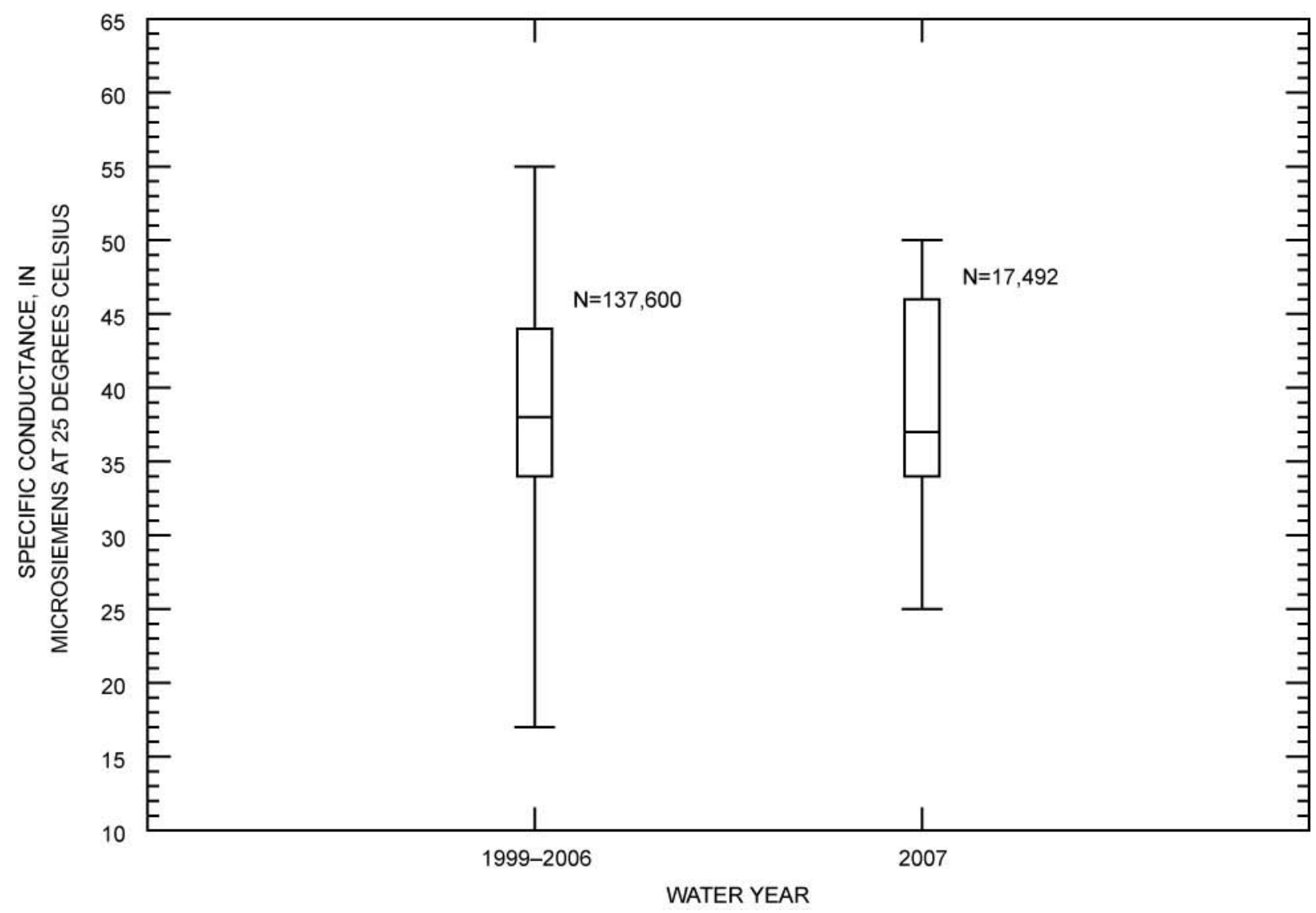

Figure 24. Graph showing comparison of water year 2007 specific conductance data with combined data from water years 1999-2006 recorded at the Blowout monitoring station, North Santiam River basin, Oregon. 
North Santiam River at Niagara (Niagara)
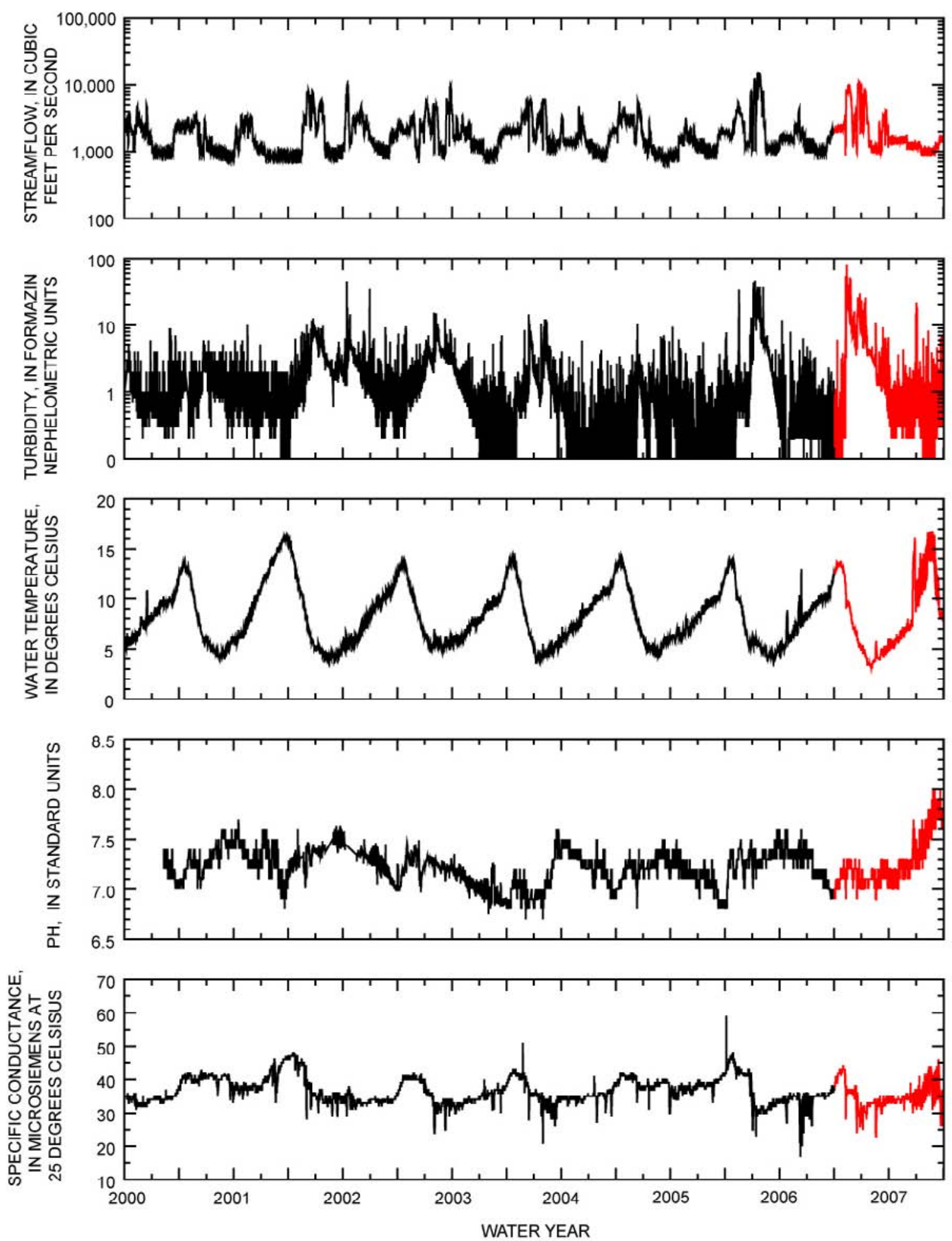

Figure 25. Graphs showing continuous values recorded at the Niagara monitoring station, North Santiam River basin, Oregon, for the period of study. Streamflow at this station is regulated by Big Cliff Dam. Water quality is generally stable, except during a few days to weeks following a major storm or other turbidity-causing event, such as a debris flow in the upper basin. 

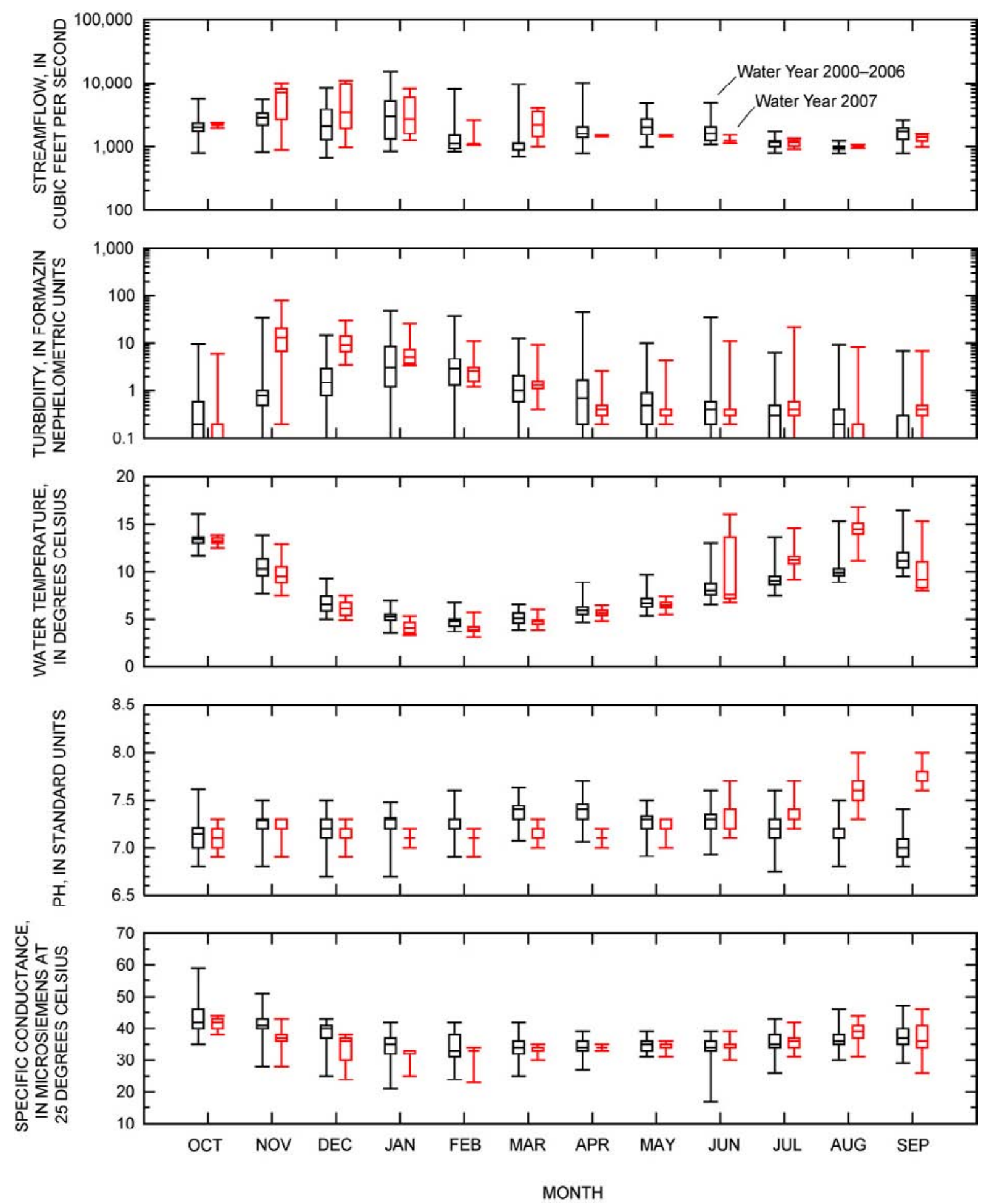

Figure 26. Graphs showing comparison of monthly water year 2007 streamflow, turbidity, water temperature, $\mathrm{pH}$, and specific conductance to water year 2000-06 values recorded at the Niagara monitoring station, North Santiam River basin, Oregon. 


\section{Streamflow}

- WY 2007 streamflows were generally similar to those of previous years (figs. 25, 26, and 27), although flows in November and December were notably higher in WY 2007, and summer flows were generally lower (fig. 26).

- No annual site maximum or minimum was established during WY 2007, but monthly peak streamflows were established in November and December 2006. Also, a greater percentage of streamflows greater than p95 occurred in WY 2007: 10 percent in WY 2007 compared to 3.4 percent in WY 1955-2006.

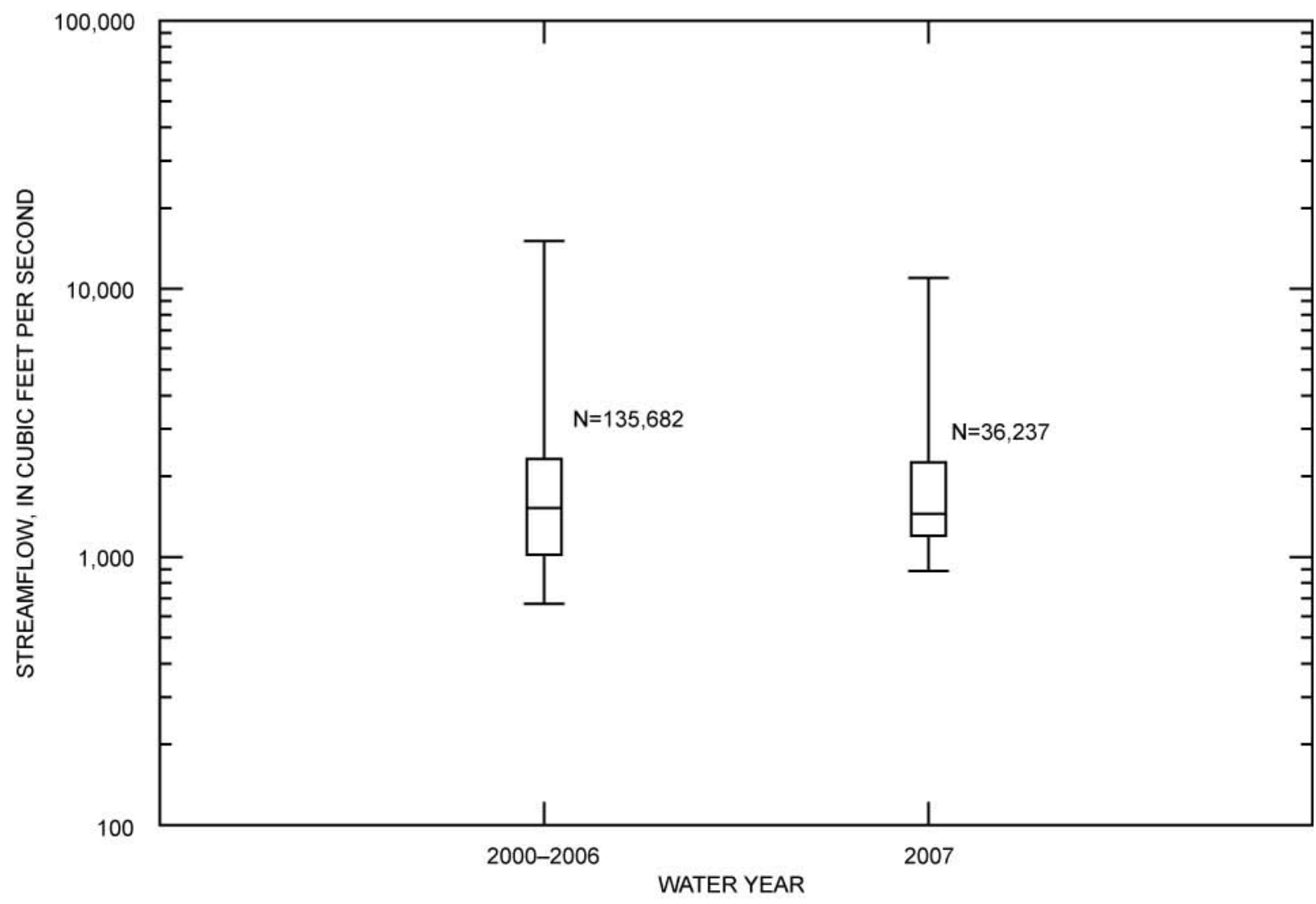

Figure 27. Graph showing comparison of water year 2007 streamflow data with combined data from water years 2000-06 recorded at the Niagara monitoring station, North Santiam River basin, Oregon. 


\section{Turbidity}

- Turbidity values above the median in WY 2007 were generally higher than in previous years of record (fig. 28). New peak turbidity for the period of study was set in November of WY 2007 following the record high turbidity estimated at North Santiam caused by the November debris flow (fig. 26).

- In water years prior to 2007, 1.9 percent of values were greater than $10 \mathrm{FNU}$ and 0 percent of values were greater than 50 FNU, whereas in WY 2007, a high-flow year, 8.7 percent of values were greater than $10 \mathrm{FNU}$ and 0.1 percent of values were greater than $50 \mathrm{FNU}$.

- Maximum monthly turbidity values for the period of study were established in November, December, and July of WY 2007, and the previous monthly maximum turbidity was equaled in September (fig. 26).

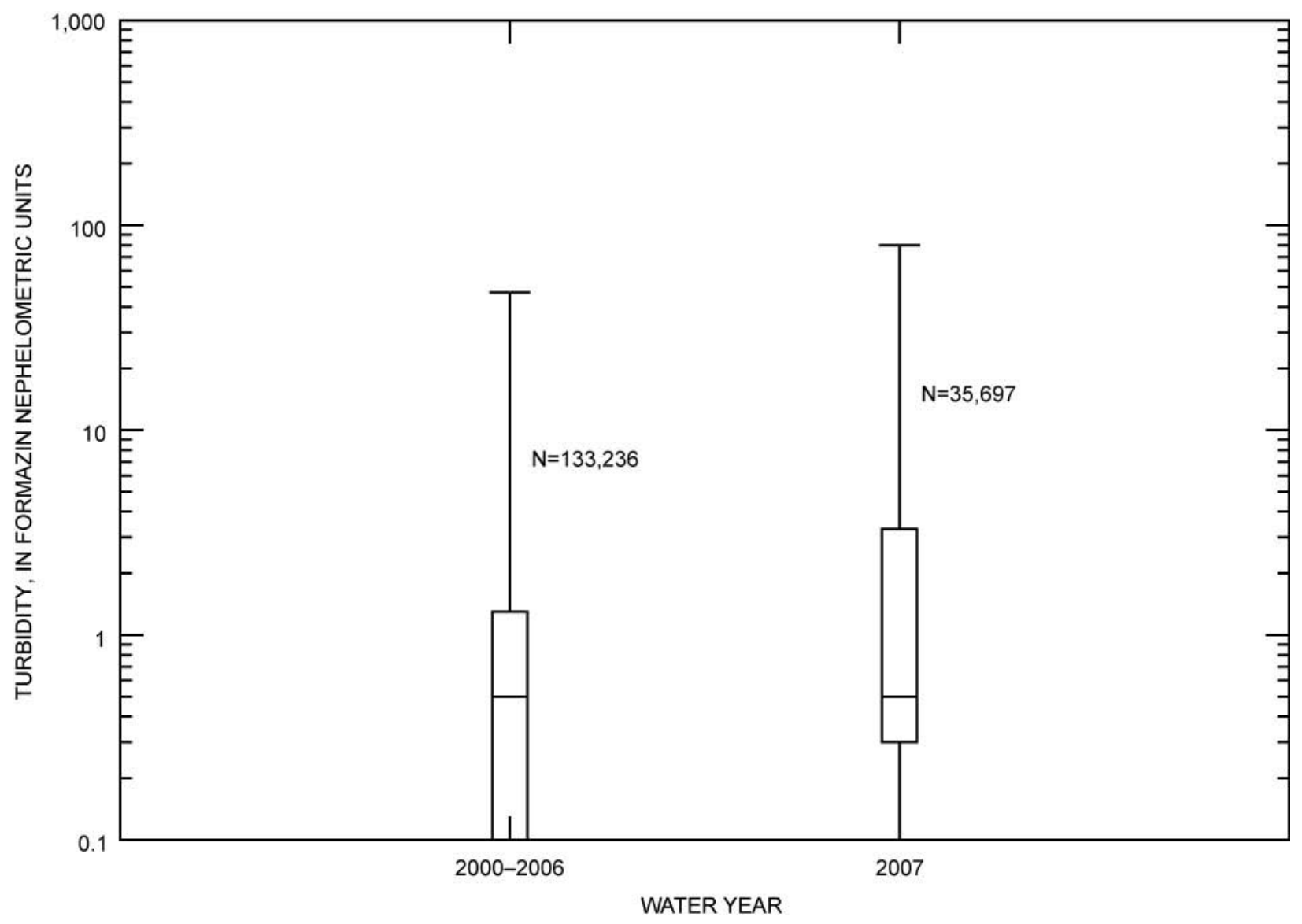

Figure 28. Graph showing comparison of water year 2007 turbidity data with combined data from water years 2000-06 recorded at the Niagara monitoring station, North Santiam River basin, Oregon. 


\section{Water Temperature}

- Stream temperatures in WY 2007 were similar to those in past years (figs. 25 and 26), although the minimum and maximum temperatures in WY 2007 were new records (fig. 29).

- $\quad$ Stream temperatures in spring of WY 2007 were slightly lower than in past years, whereas summer temperatures were higher (figs. 25 and 26). New monthly minimum temperatures were established during November-February (monthly minimums were equal in March) and in September; new monthly maximums were recorded during June-August.

- At least some values were higher than the $13^{\circ} \mathrm{C}$ and $16^{\circ} \mathrm{C}$ State standards for Spawning and Core Coldwater Habitat during the relevant dates for each (figs. 25 and 26). However, because these values were instantaneous and no running average was calculated, they do not constitute exceedences of the standards.

- The Core Coldwater habitat standard $\left(16^{\circ} \mathrm{C}\right)$ was equaled in June and exceeded in August for the first time since the monitoring station was established, WY 2000 (figs. 25 and 26).

- The spawning period standard $\left(13^{\circ} \mathrm{C}\right)$ was exceeded in September of both the WY 2007 and preWY 2007 record (figs. 25 and 26).

- Seventy-five percent of values for October, both in WY 2007 and in years prior, were equal to or greater than the spawning period standard $\left(13^{\circ} \mathrm{C}\right)$ (fig. 26$)$.

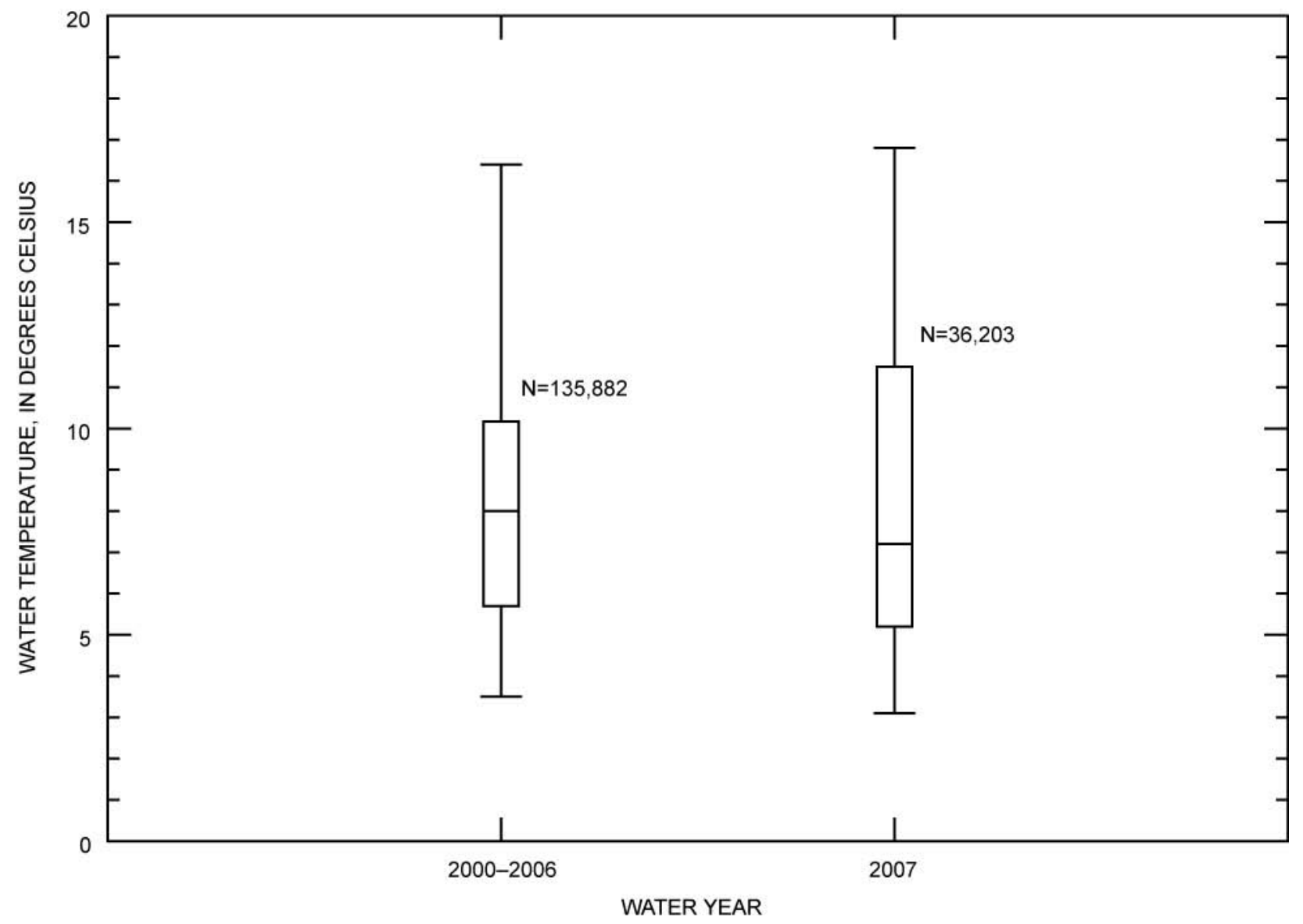

Figure 29. Graph showing comparison of water year 2007 water temperature data with combined data from water years 2000-06 recorded at the Niagara monitoring station, North Santiam River basin, Oregon. 
- $\quad$ Overall pH values were similar between WY 2007 and previous years (figs. 25 and 30). No State standards were exceeded in WY 2007 or in previous years; however, new monthly and period of study peaks were established in summer of WY 2007 (fig. 26).

- About 5 percent of WY $2007 \mathrm{pH}$ values were greater than the previous maximum value (fig. 30).

- $\quad$ pH values in WY 2007 were lower than normal in late winter and spring, and much higher than normal in late summer (figs. 25 and 26).

- $\quad$ New monthly maximum pH values were established during June-September (fig. 26).

- New monthly minimum pH values were established in March and April, 2007, and monthly minimum $\mathrm{pH}$ values were equaled in February (fig. 26).

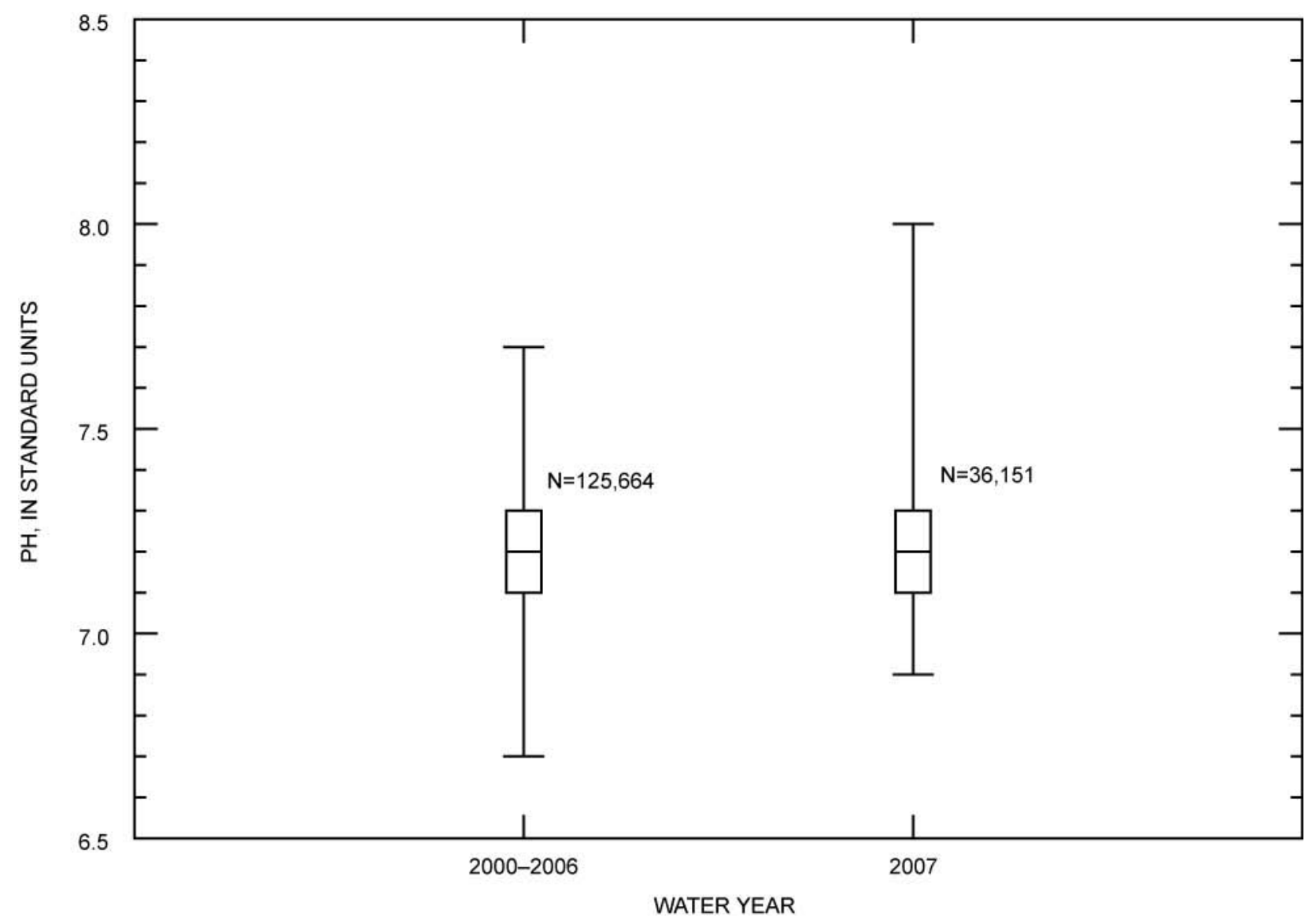

Figure 30. Graph showing comparison of water year $2007 \mathrm{pH}$ data with combined data from water years 2000-06 recorded at the Niagara monitoring station, North Santiam River basin, Oregon. 


\section{Specific Conductance}

- Most of the WY 2007 specific conductance values were similar to those of previous years (figs. 25 and 26), but the WY 2000-06 record had higher and lower outliers (fig. $31)$.

- The monthly maximum specific conductance in June was equal to the WY 2000-06 June maximum (fig. 26).

- Monthly minimum specific conductance values were established in December, February, and September and equaled in November and May (fig. 26).

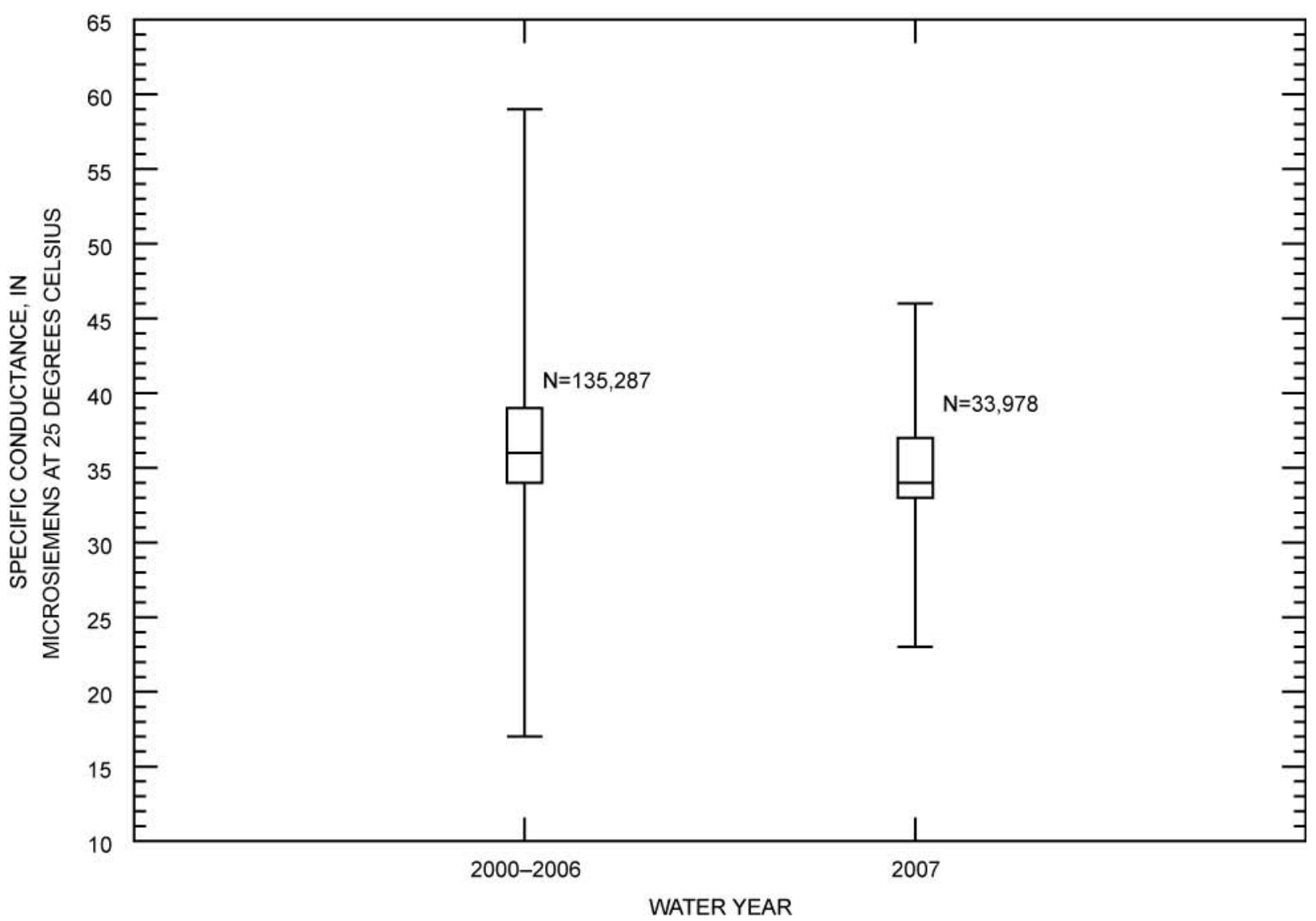

Figure 31. Graph showing comparison of water year 2007 specific conductance data with combined data from water years 2000-06 recorded at the Niagara monitoring station, North Santiam River basin, Oregon. 


\section{Rock Creek near Mill City (Rock)}

Data collection began at this site in 2005. Because the pre-WY 2007 record is limited to 1 year, no meaningful comparisons can be made between WY 2007 and the prior record.
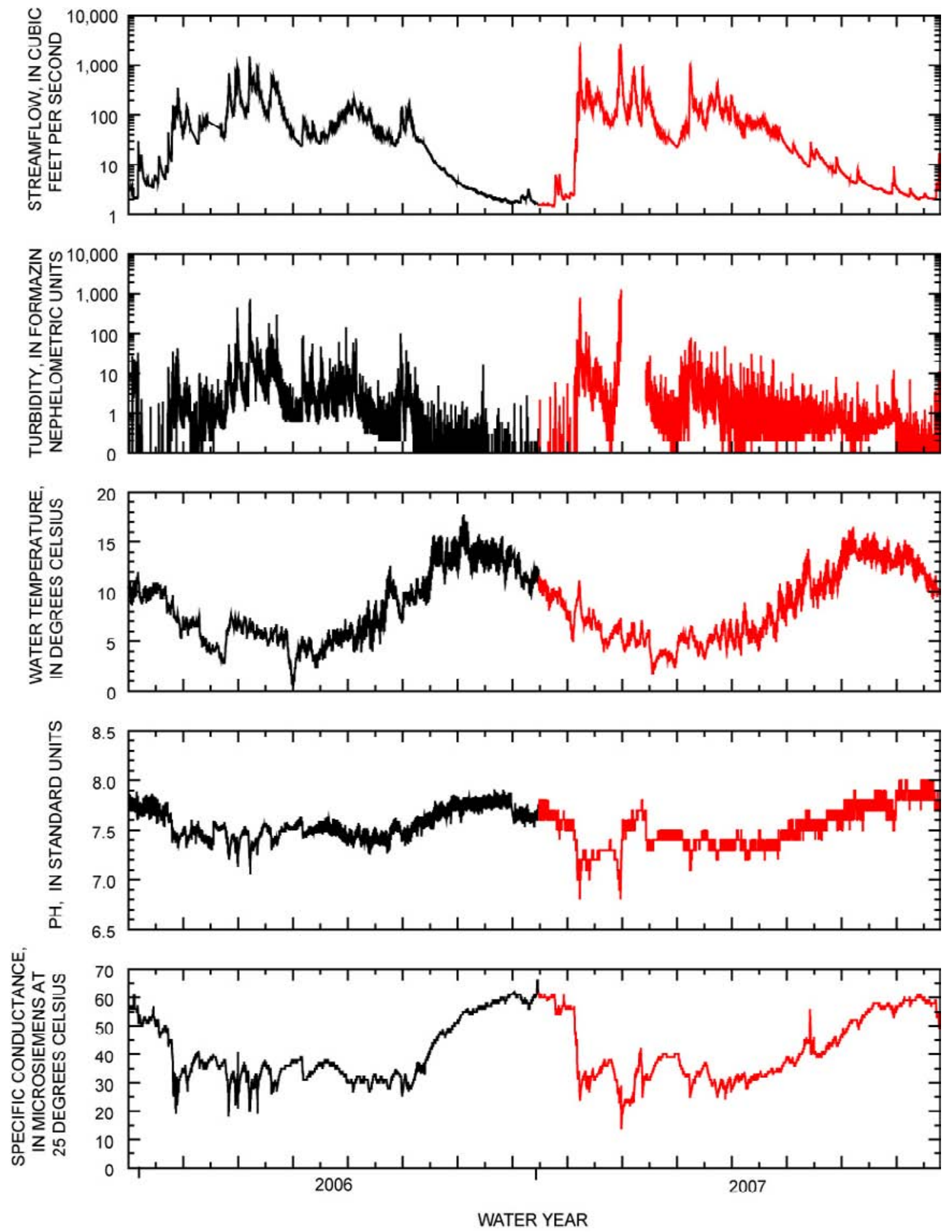

Figure 32. Graphs showing continuous values recorded at the Rock monitoring station, North Santiam River basin, Oregon, for the period of record. 

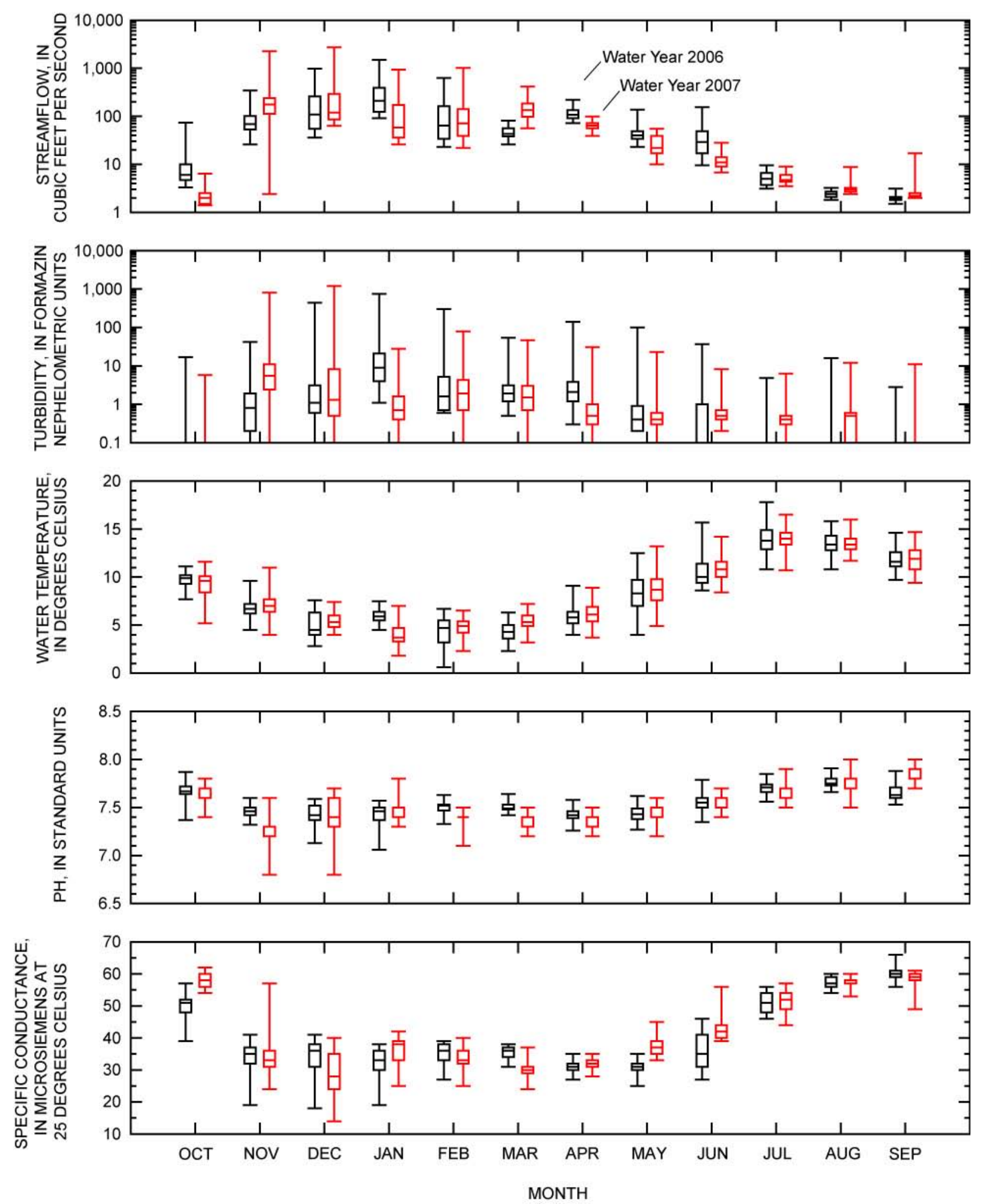

Figure 33. Graphs showing comparison of monthly water year 2007 streamflow, turbidity, water temperature, $\mathrm{pH}$, and specific conductance to water year 2006 values recorded at the Rock monitoring station, North Santiam River basin, Oregon 


\section{Streamflow}

- Streamflow in November of WY 2007 varied widely, from low flows at the beginning of the month to high flows after the onset of winter storms (figs. 32 and 33).

- The November and December WY 2007 maximums exceeded the maximums of WY 2006, whereas the maximums for other months in WY 2007 were generally lower than those of WY 2006 (figs. 32, 33, and 34).

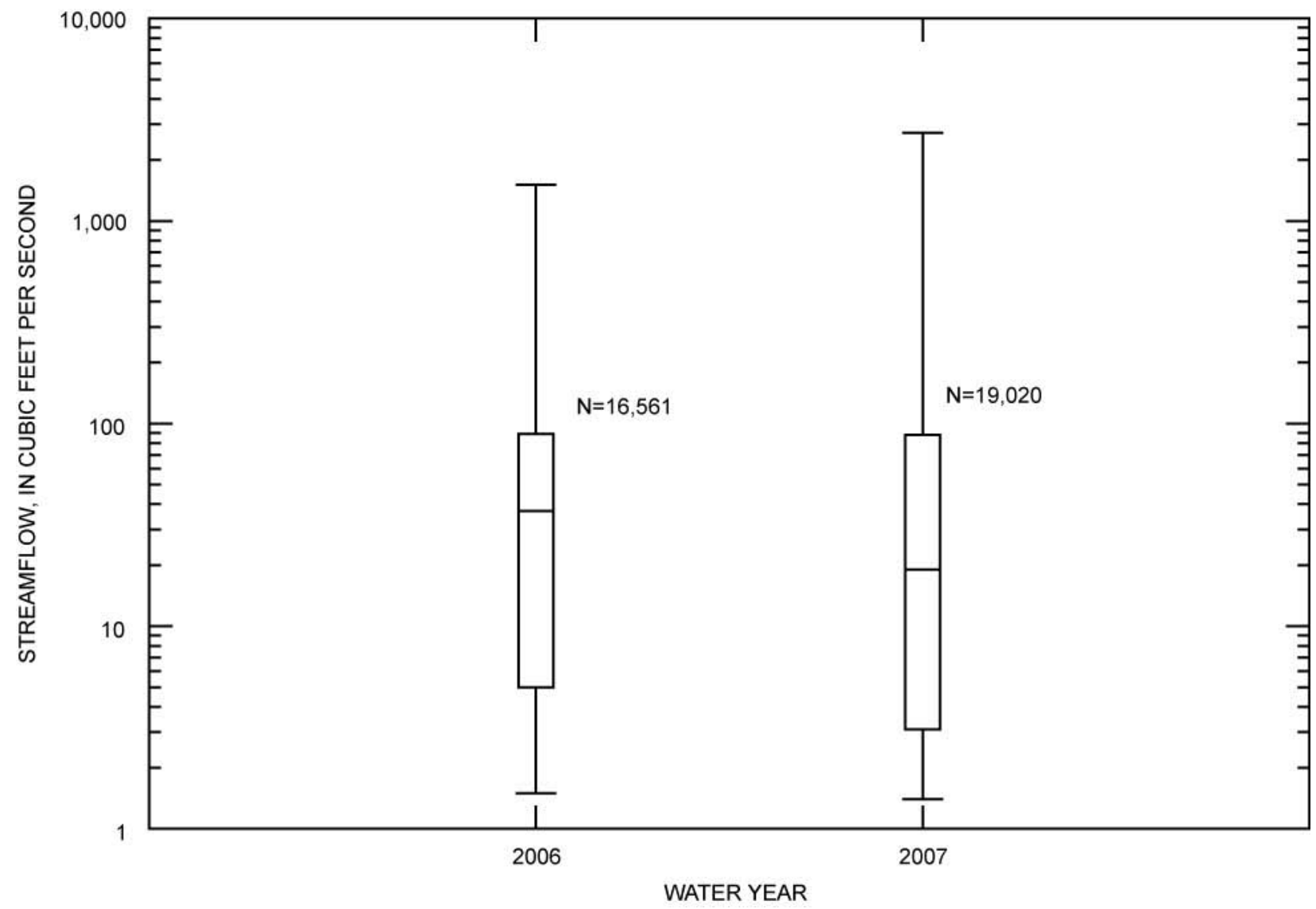

Figure 34. Graph showing comparison of water year 2007 streamflow data with the water year 2006 record for the Rock monitoring station, North Santiam River basin, Oregon. 


\section{Turbidity}

- Turbidity surpassed the sensor maximum in December of WY 2007, so the maximum values shown in figures 32 and 33 are less than the actual values attained; some data were deleted because the monitor was buried by the river's substrate (fig. 32).

- Even though WY 2007 maximum values were higher than WY 2006 maximum values (figs. 32, 33 and 35), in WY 2006, 7.2 percent of values were greater than $10 \mathrm{FNU}$ and 0.9 percent of values were greater than $50 \mathrm{FNU}$, whereas in WY 2007, 4.0 percent of values were greater than $10 \mathrm{FNU}$ and 0.8 percent of values were greater than $50 \mathrm{FNU}$.

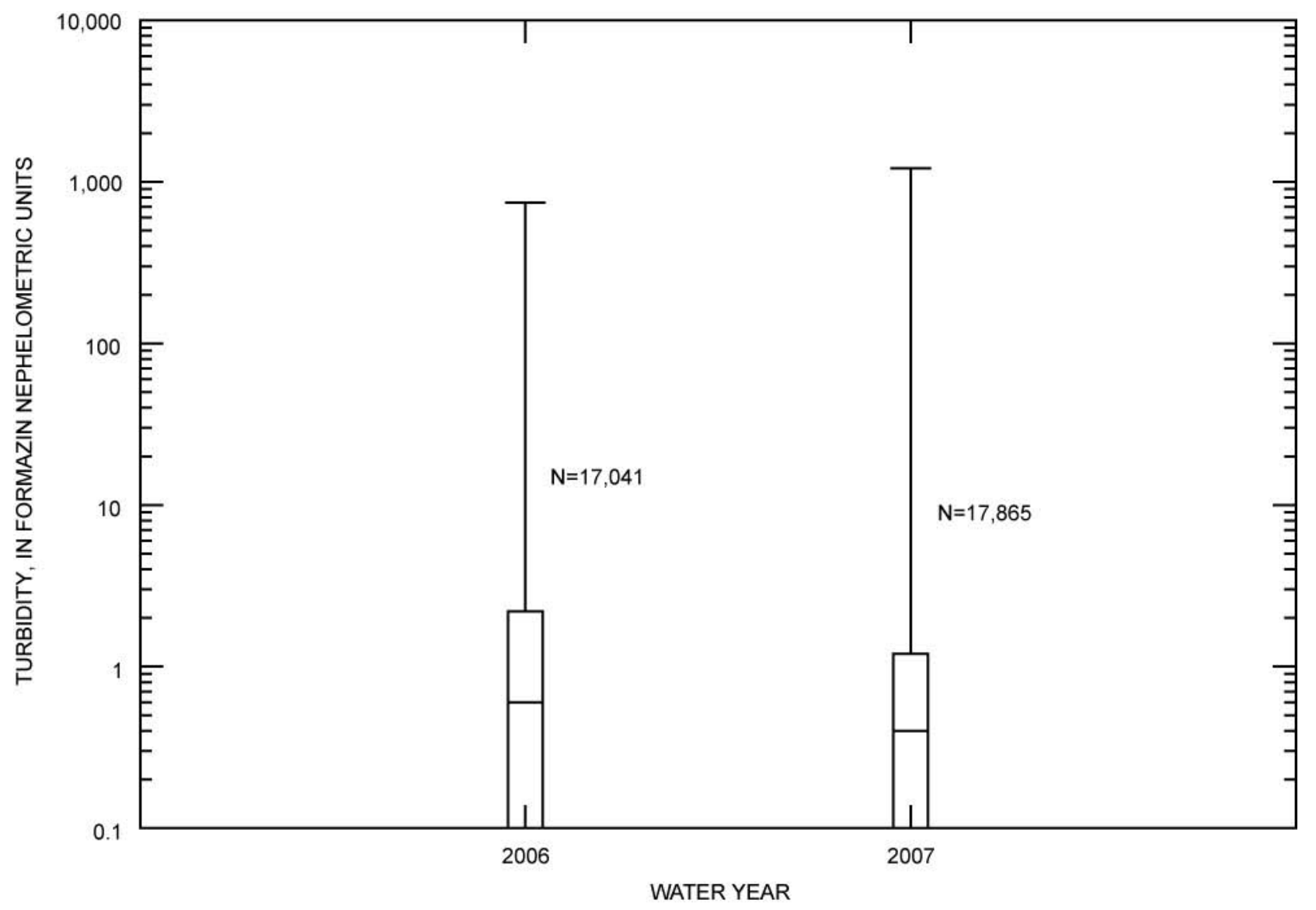

Figure 35. Graph showing comparison of water year 2007 turbidity data with the water year 2006 record for the Rock monitoring station, North Santiam River basin, Oregon. 


\section{Water Temperature}

- The Core Coldwater habitat standard $\left(16^{\circ} \mathrm{C}\right)$ was exceeded in July of both water years and matched by one value in August 2007.

- $\quad$ The Spawning standard $\left(13^{\circ} \mathrm{C}\right)$ was exceeded occasionally in May 2007 and frequently in September of both water years.

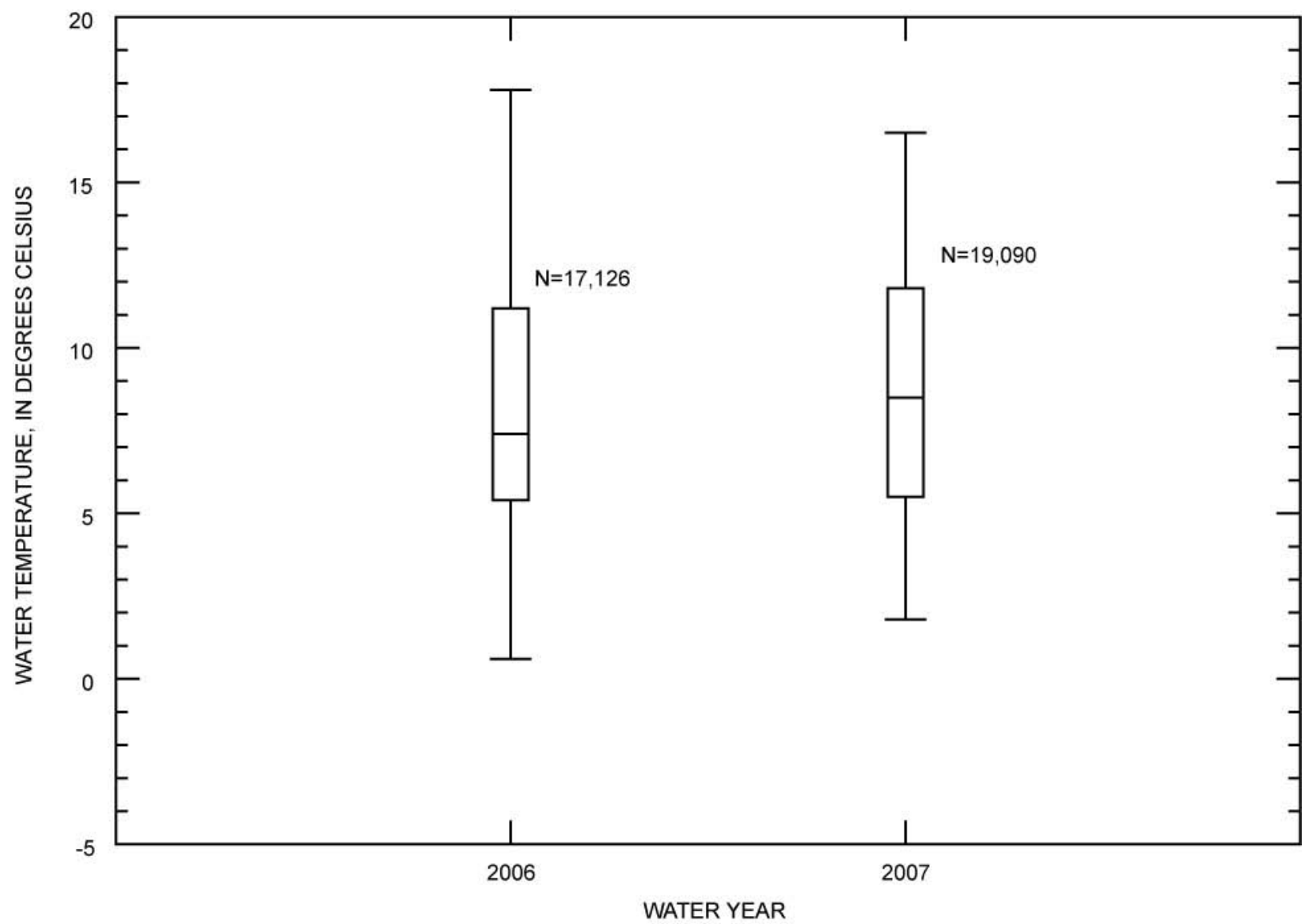

Figure 36. Graph showing comparison of water year 2007 water temperature data with the water year 2006 record for the Rock monitoring station, North Santiam River basin, Oregon. 
$\mathrm{pH}$

- $\mathrm{pH}$ values remained within the range of the minimum and maximum State standards during both years (figs. 32, 33, and 37).

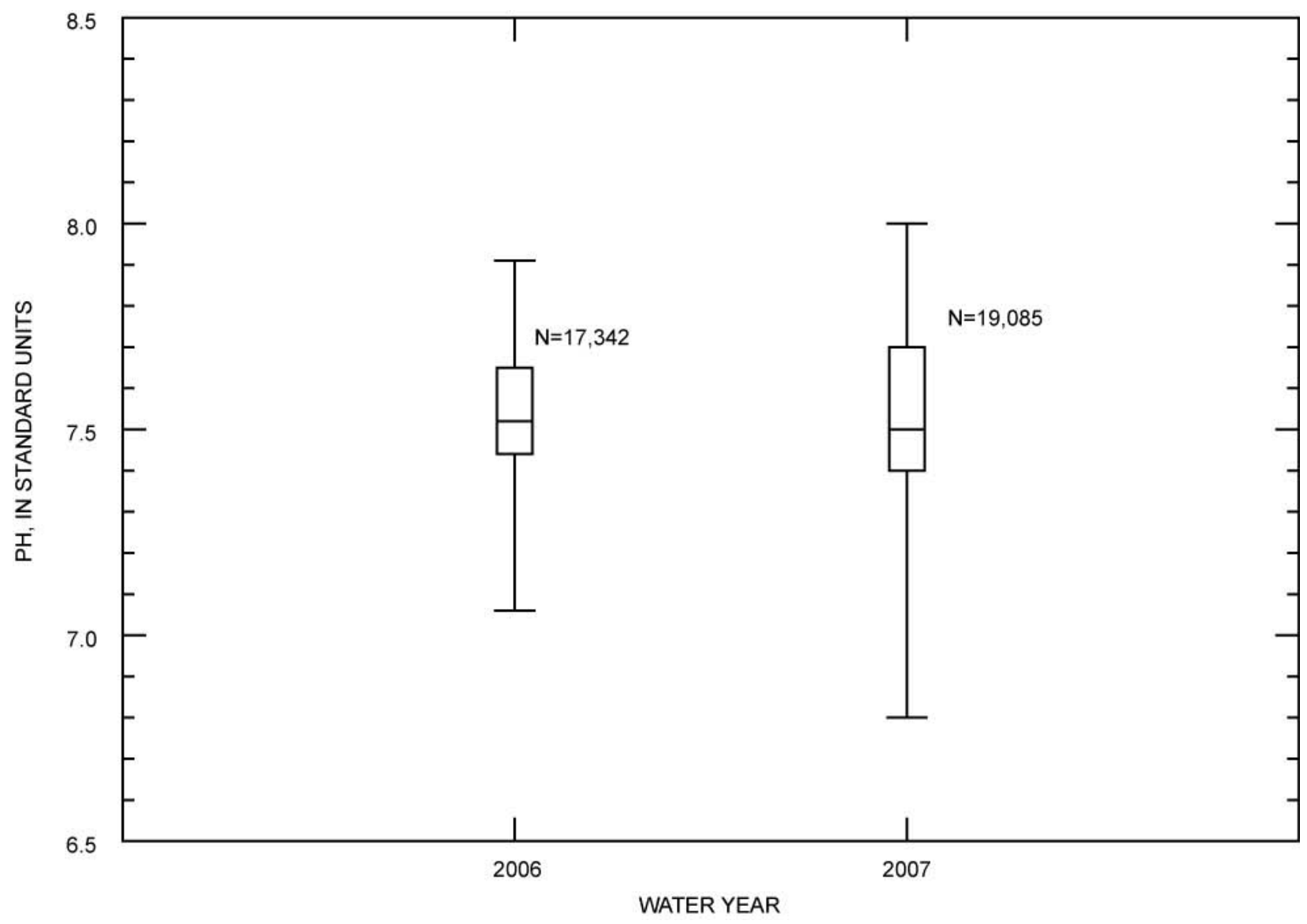

Figure 37. Graph showing comparison of water year $2007 \mathrm{pH}$ data with the water year 2006 record for the Rock monitoring station, North Santiam River basin, Oregon. 


\section{Specific Conductance}

- $\quad$ Specific conductance varied considerably during the two water years (figs. 32, 33, and 38). In WY 2006, 14.5 percent of values were less than $30 \mu \mathrm{S} / \mathrm{cm}$ and 25.3 percent of values were greater than $50 \mu \mathrm{S} / \mathrm{cm}$. In WY 2007, 12.2 percent of values were less than $30 \mu \mathrm{S} / \mathrm{cm}$ and 36.4 percent of values were greater than $50 \mu \mathrm{S} / \mathrm{cm}$.

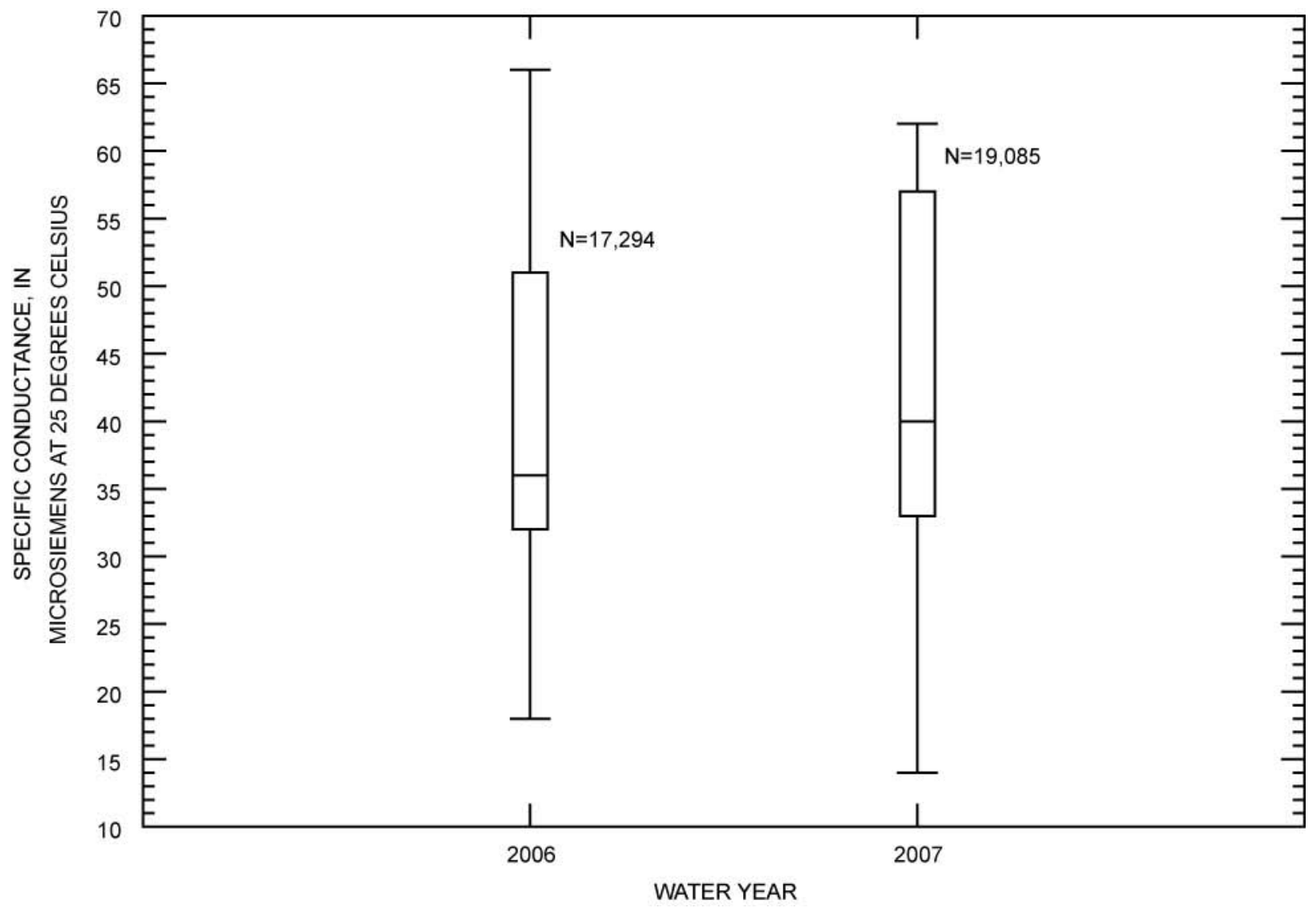

Figure 38. Graph showing comparison of water year 2007 specific conductance data with the water year 2006 record for the Rock monitoring station, North Santiam River basin, Oregon. 
Little North Santiam River near Mehama (Little North)
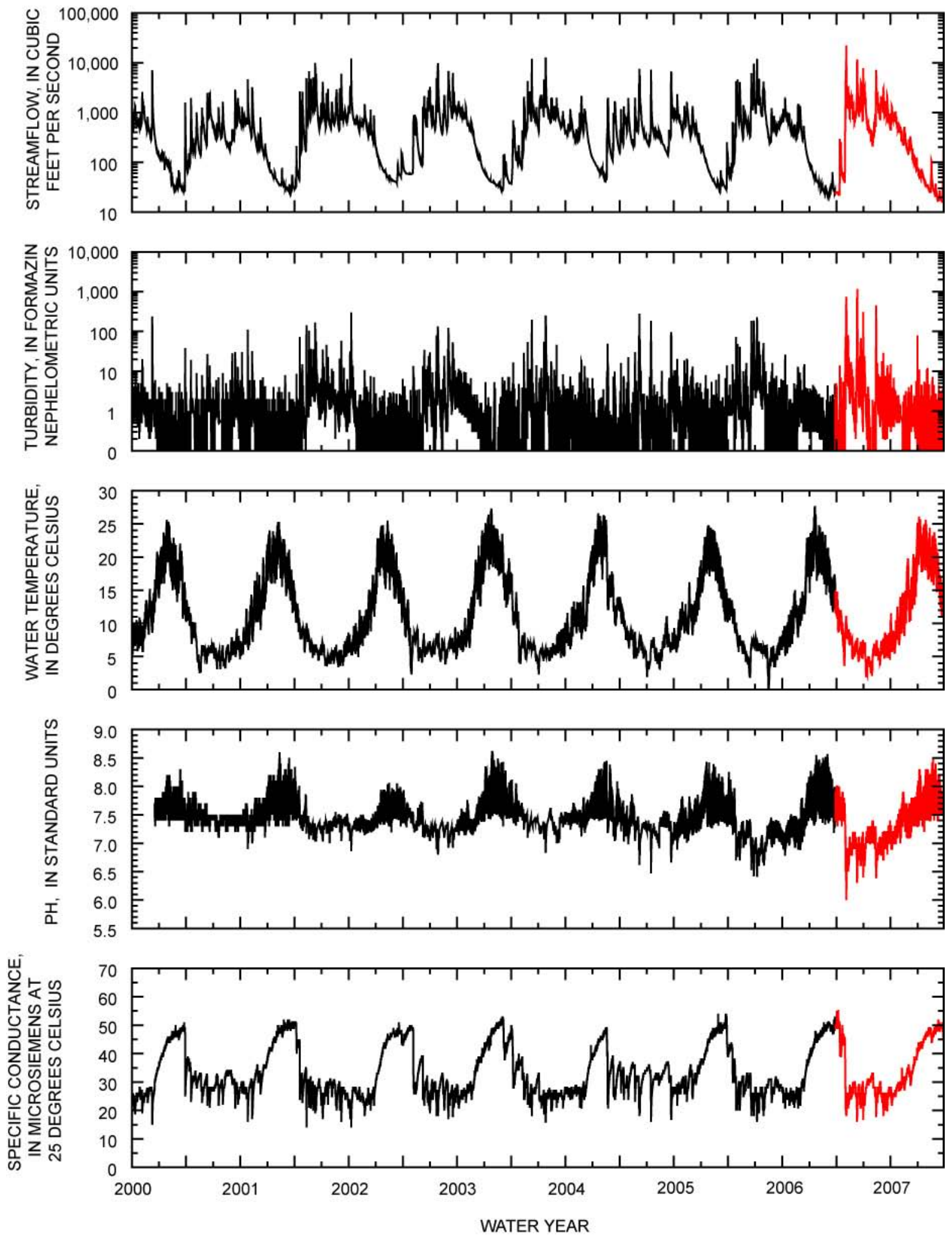

Figure 39. Graphs showing continuous values recorded at the Little North monitoring station, North Santiam River basin, Oregon, for the period of study. 

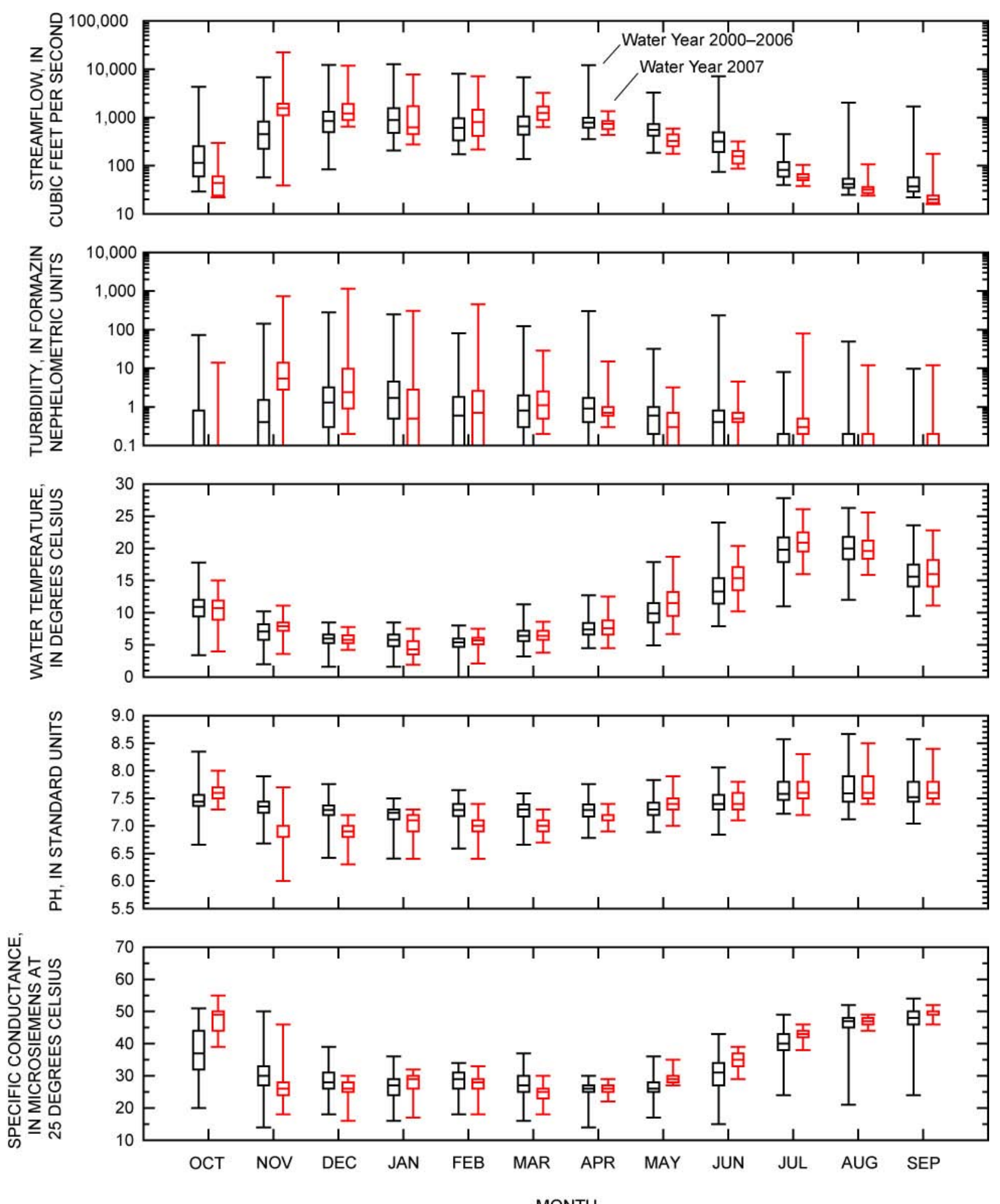

Figure 40. Graphs showing comparison of monthly water year 2007 streamflow, turbidity, water temperature, pH, and specific conductance to water year 2000-06 values recorded at the Little North monitoring station, North Santiam River basin, Oregon. 


\section{Streamflow}

- New minimum and maximum values for the period of study were established in WY 2007 (figs. 39, 40, and 41).

- The WY 2007 median value was about $100 \mathrm{ft}^{3} / \mathrm{s}$ less than the median value for the WY 2000-06 period of record (fig. 41).

- $\quad$ During WY 2007, approximately 16 percent of values were less than p5 compared with 5.2 percent for WY 2000-06.

- Period of study peak streamflows occurred in November 2006 and higher than normal streamflows were recorded in December 2006 (figs. 39 and 40).

- Period of record monthly low streamflows occurred in WY 2007 during October, November, May, July, August, and September.

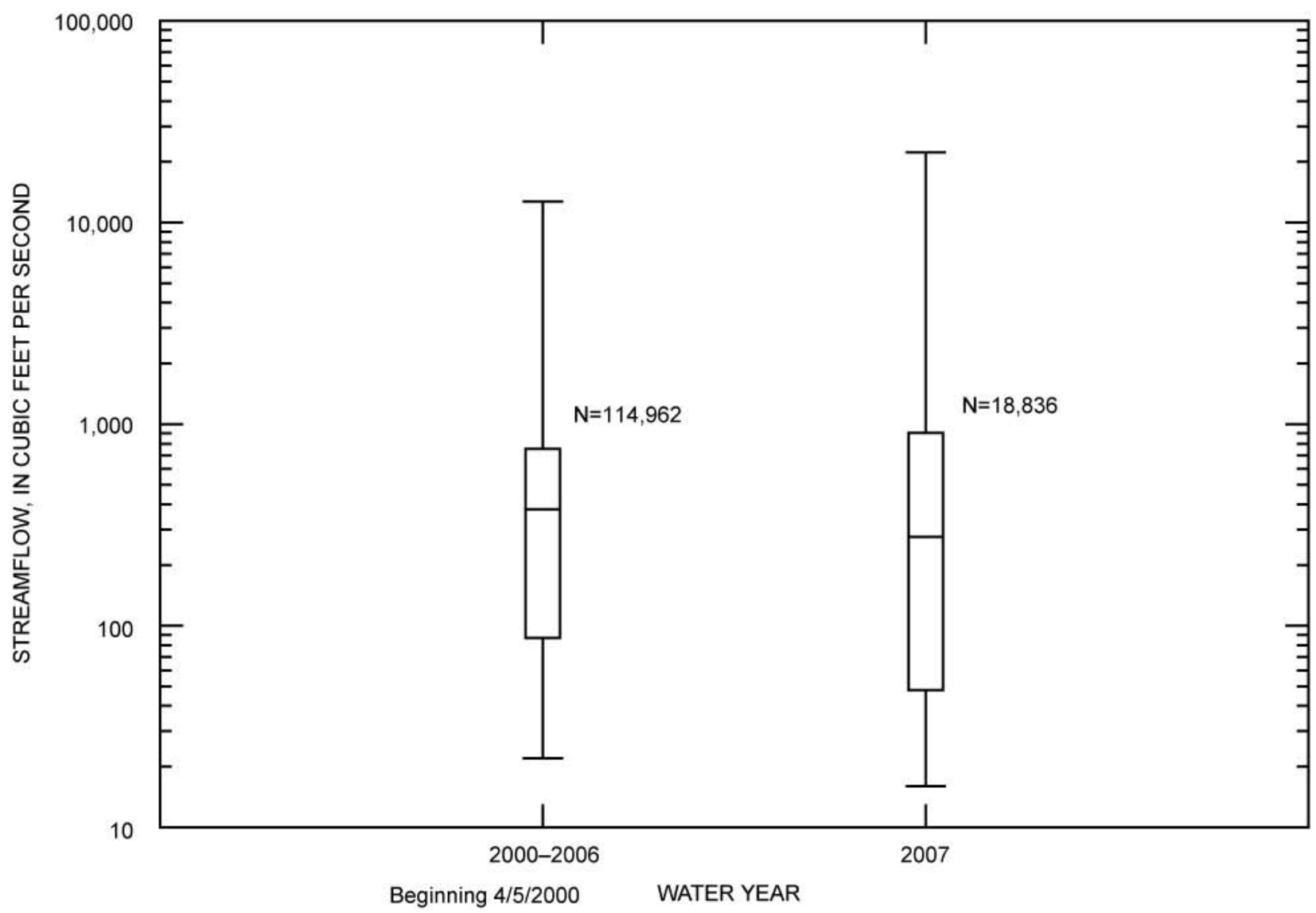

Figure 41. Graph showing comparison of water year 2007 streamflow data with combined data from water years 2000-06 recorded at the Little North monitoring station, North Santiam River basin, Oregon. 


\section{Turbidity}

- In WY 2007, a period of study maximum turbidity value was established (figs. 39, 40, and 42). The true value is not known because of the limitations of the turbidity probe; however, the maximum was equal to or greater than 1,160 FNU.

- Exceedence of the $50 \mathrm{FNU}$ threshold was more common at Little North than at other sites in WY 2007. In water years prior to 2007, 3.2 percent of values were greater than $10 \mathrm{FNU}$ and 0.6 percent of values were greater than $50 \mathrm{FNU}$. In WY 2007, 6.0 percent of values were greater than $10 \mathrm{FNU}$ and 2.0 percent of values were greater than $50 \mathrm{FNU}$.

- New monthly maximum turbidity values were established in November, December, January, February, July, and September of WY 2007.

- November 2006 (WY 2007) turbidity was considerably higher than the aggregated WY 2000-06 November data for the site.

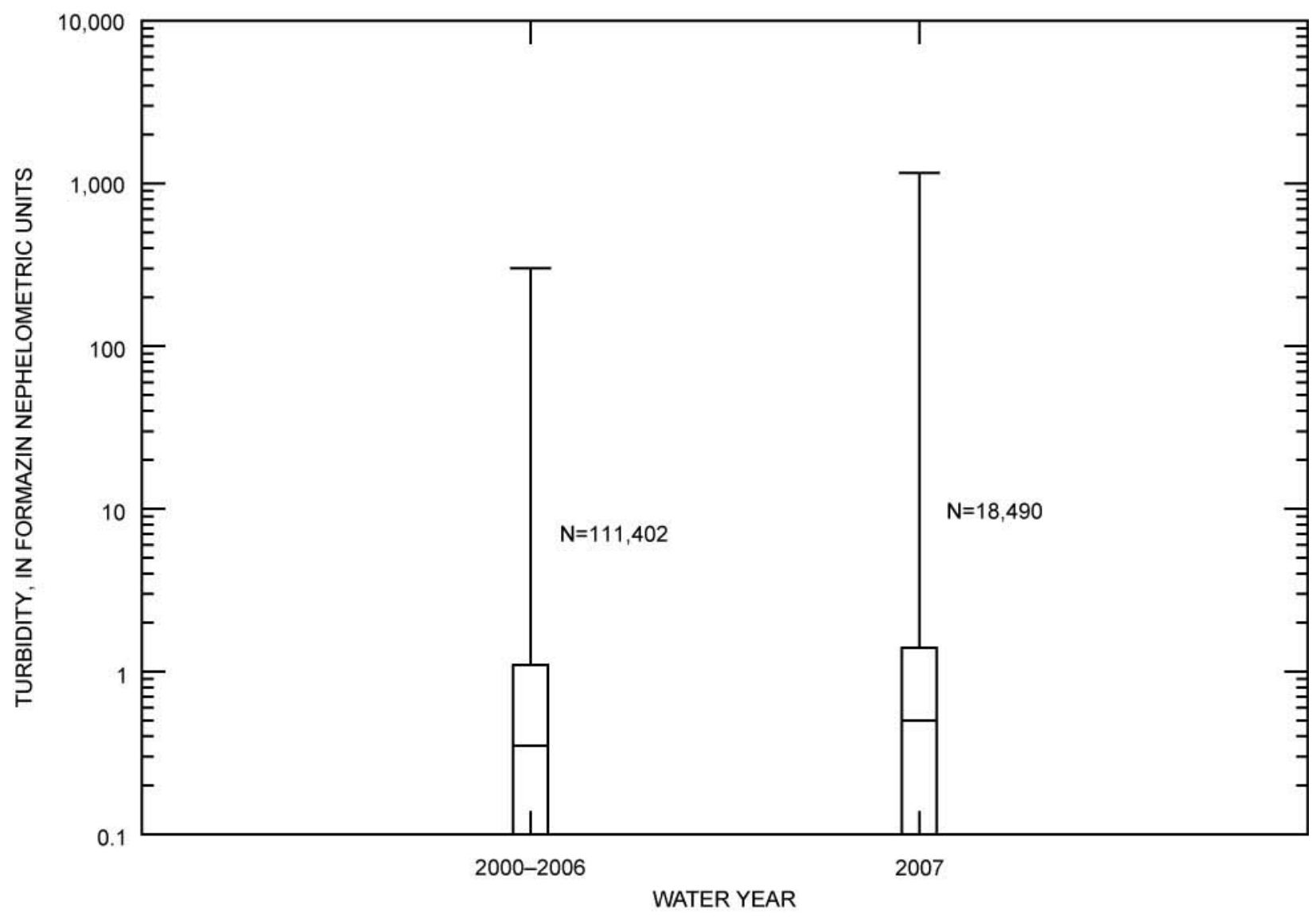

Figure 42. Graph showing comparison of water year 2007 turbidity data with combined data from water years 2000-06 recorded at the Little North monitoring station, North Santiam River basin, Oregon. 


\section{Water Temperature}

- Water temperatures in WY 2007 were comparable to those of previous years (figs. 39 and 40), although the 75th percentile was about $2^{\circ} \mathrm{C}$ higher in WY 2007 (fig. 43).

- Temperatures at this site regularly exceed the State standards for both Spawning and Core Coldwater habitat (figs. 39 and 40).

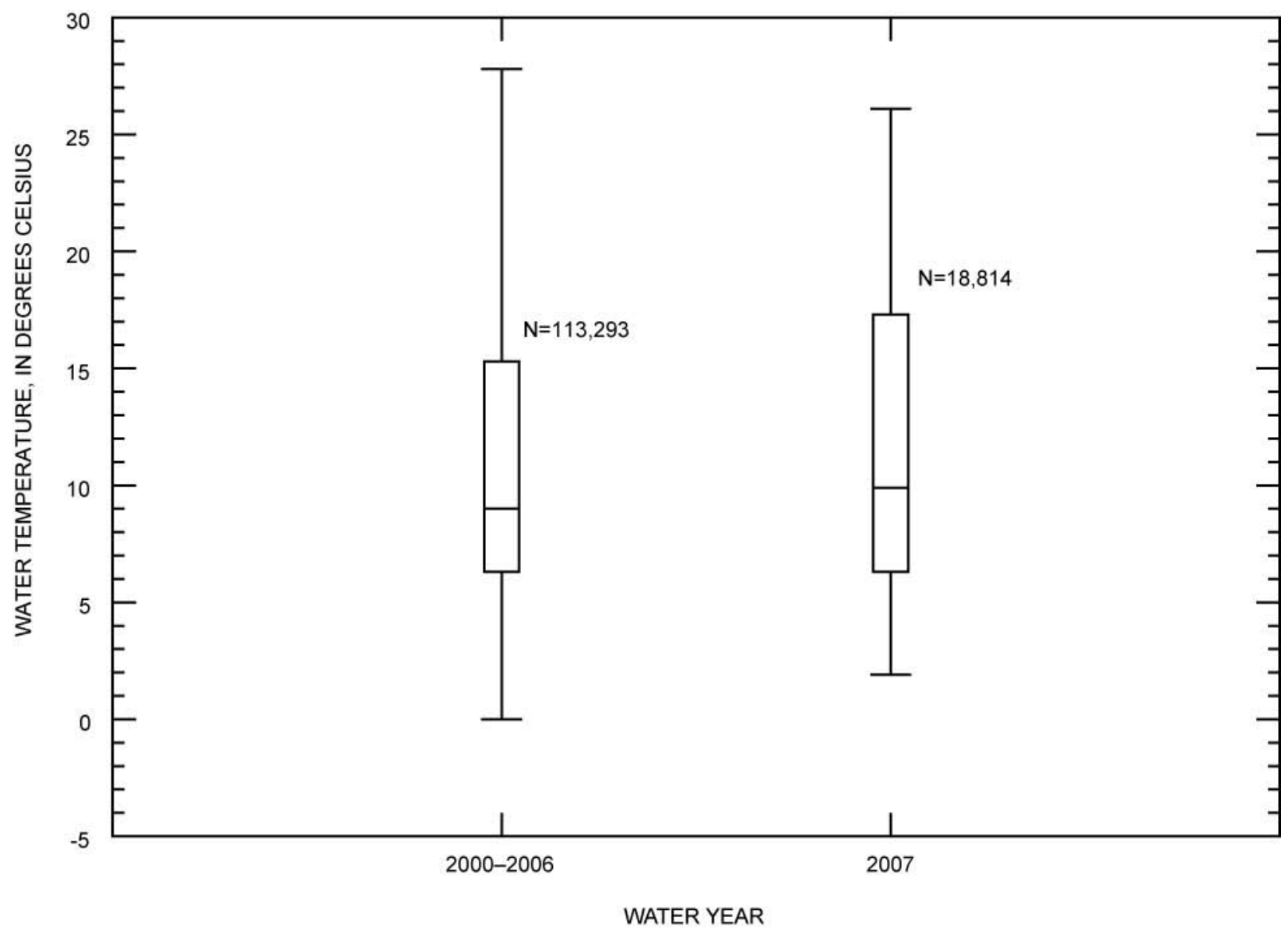

Figure 43. Graph showing comparison of water year 2007 water temperature data with combined data from water years 2000-06 recorded at the Little North monitoring station, North Santiam River basin, Oregon. 
- $\quad$ The range of pH values was comparable between WY 2007 and previous years (figs. 39, 40, and 44), but values were somewhat lower in winter and spring of WY 2007.

- $\mathrm{pH}$ values at this site occasionally exceed both the maximum and minimum State standards of 8.5 and 6.5, respectively (figs. 39, 40, and 44).

- A new monthly maximum pH value was recorded in May 2007 (fig. 40).

- $\quad$ New minimum pH values were recorded in November, December, January, February, and July of WY 2007 (fig. 40).

- More than 75 percent of November 2006 (WY 2007) pH values were less than the 25th percentile of the pre-2007 data.

- All December 2006 (WY 2007) values were equal to or less than the 25th percentile of pre-2007 data.

- $\quad$ The minimum State standard for $\mathrm{pH}$ was exceeded during November-February. In previous water years, only in December and January were values less than 6.5 units.

- $\quad$ The State maximum pH standard (8.5 units) was equaled in August 2007 (figs. 39 and 40). In comparison, in WY 2001, 2003, and 2006 at least one value exceeded the standard in mid- to late summer.

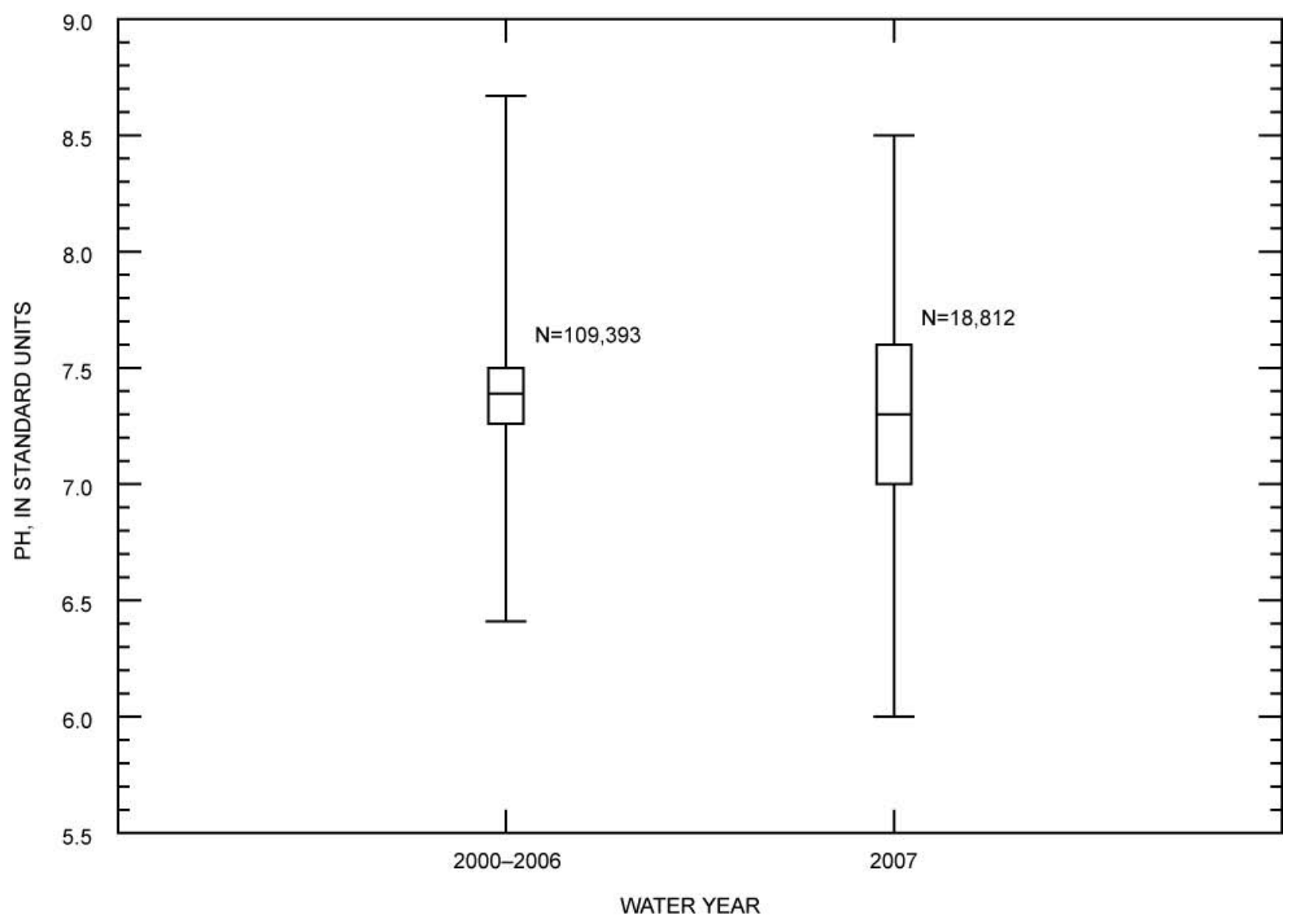

Figure 44. Graph showing comparison of water year 2007 pH data with combined data from water years 200006 recorded at the Little North monitoring station, North Santiam River basin, Oregon. 


\section{Specific Conductance}

- Specific conductance values in WY 2007 were comparable to those of previous years (figs. 39, 40, and 45). However, a new period of study maximum was established in WY 2007.

- $\quad$ The 25th to 75th percentile data in WY 2007 were broader than those in the combined prior water years (fig. 45), indicating that the data were more variable.

- Specific conductance values at this site generally are relatively low. In WY 2007 and in prior years, about one-half of the values were less than $30 \mu \mathrm{S} / \mathrm{cm}$.

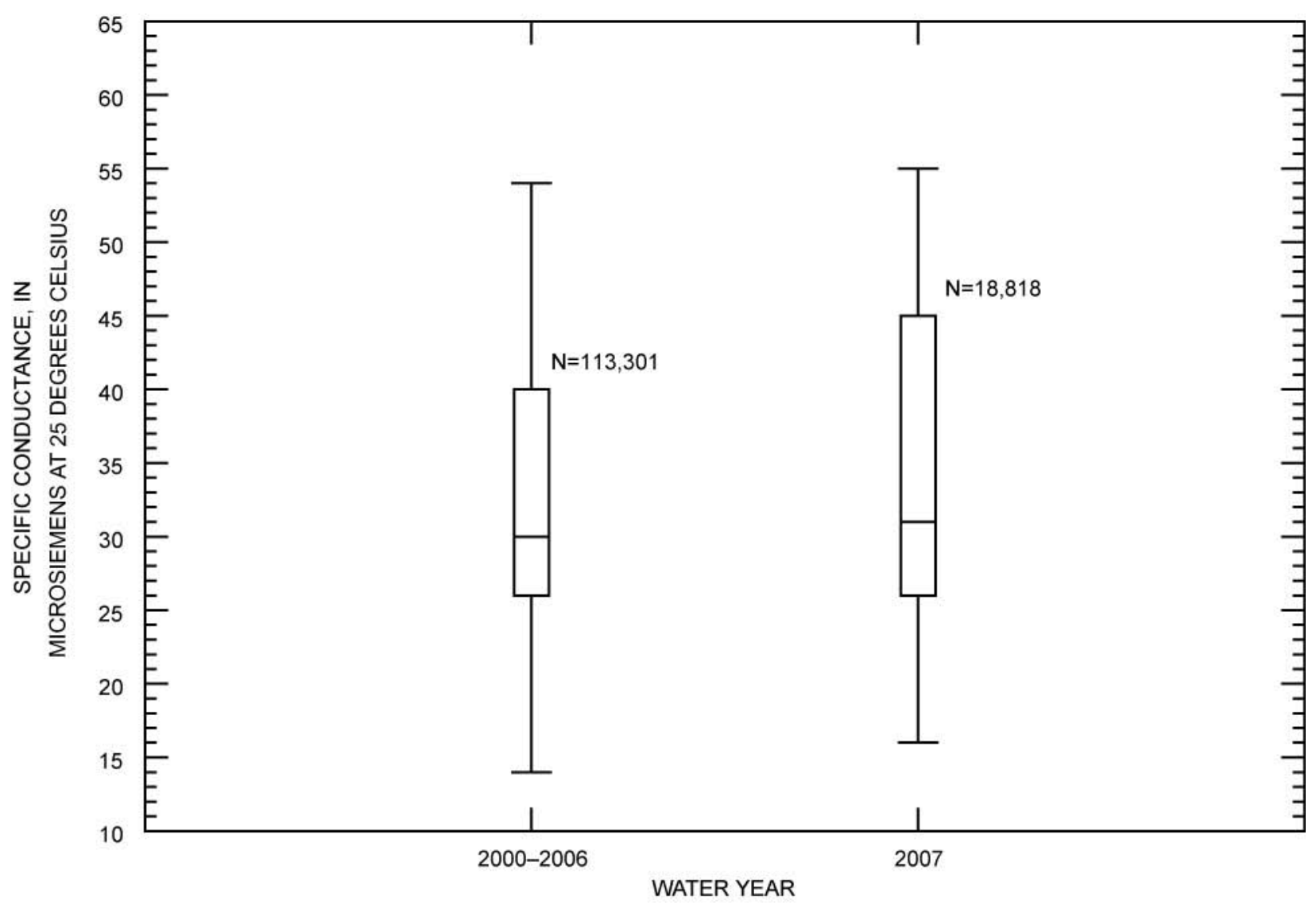

Figure 45. Graph showing comparison of water year 2007 specific conductance data with combined data from water years 2000-06 recorded at the Little North monitoring station, North Santiam River basin, Oregon. 
North Santiam River at Mehama (Mehama)
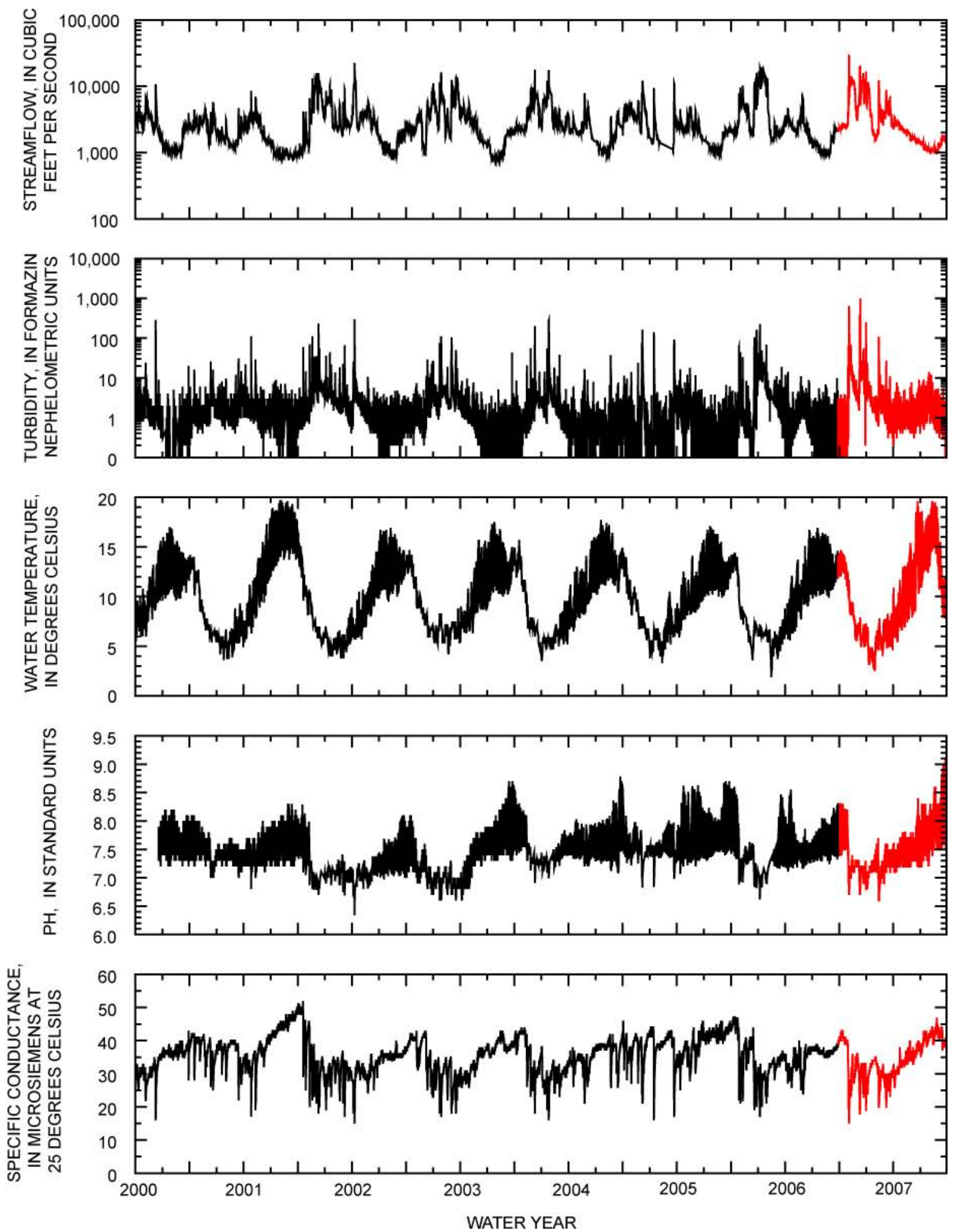

Figure 46. Graphs showing continuous values recorded at the Mehama monitoring station, North Santiam River basin, Oregon, for the period of study. 

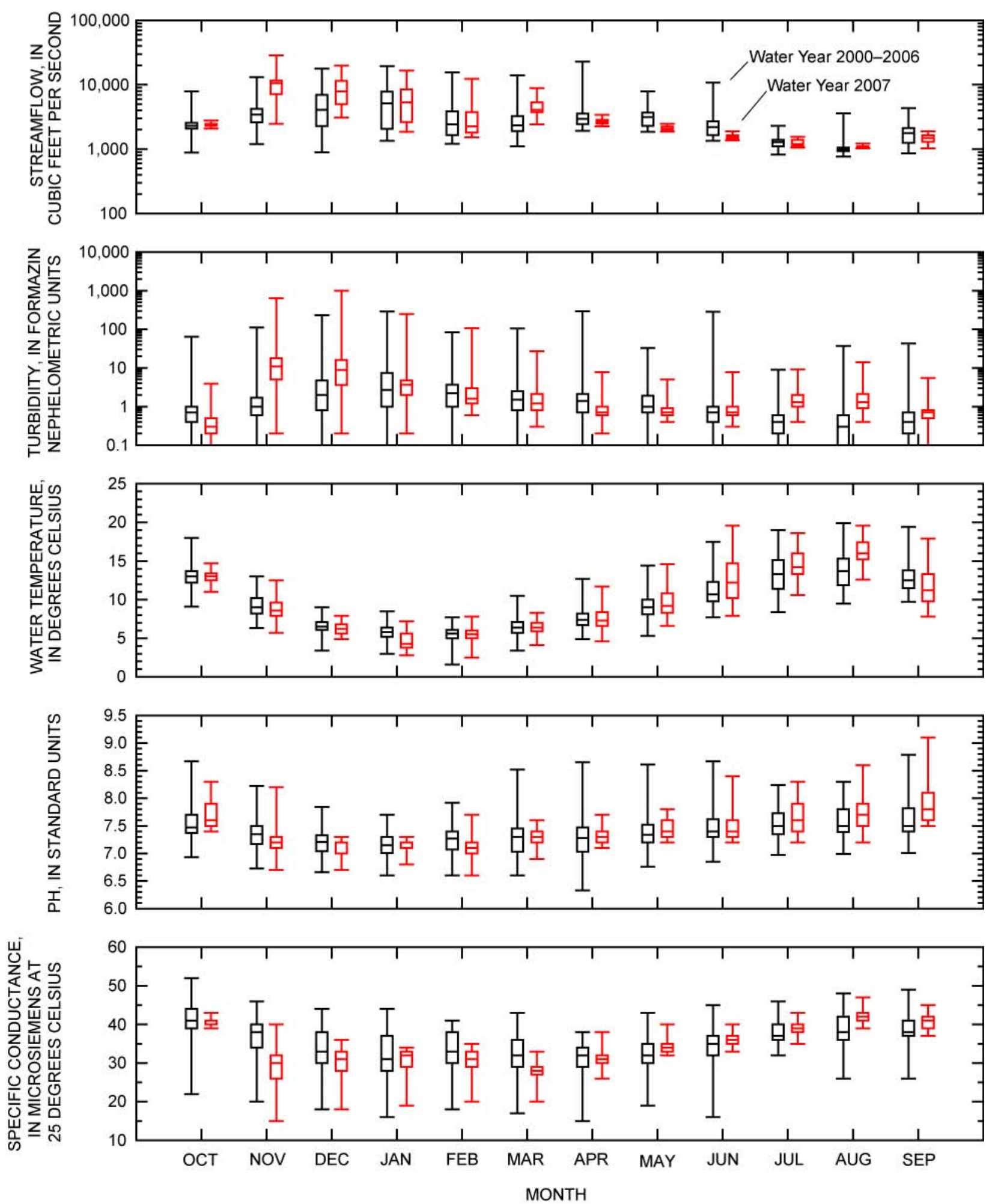

Figure 47. Graphs showing comparison of monthly water year 2007 streamflow, turbidity, water temperature, $\mathrm{pH}$, and specific conductance to water year 2000-06 values recorded at the Mehama monitoring station, North Santiam River basin, Oregon. 


\section{Streamflow}

- A new peak streamflow for the period of study was recorded in November of WY 2007 (figs. 46, 47, and 48).

- WY 2007 November, December, and March streamflows were generally much higher than in past years (figs. 46 and 47).

- WY 2007 April, May, and June streamflows were generally much lower than in past years.

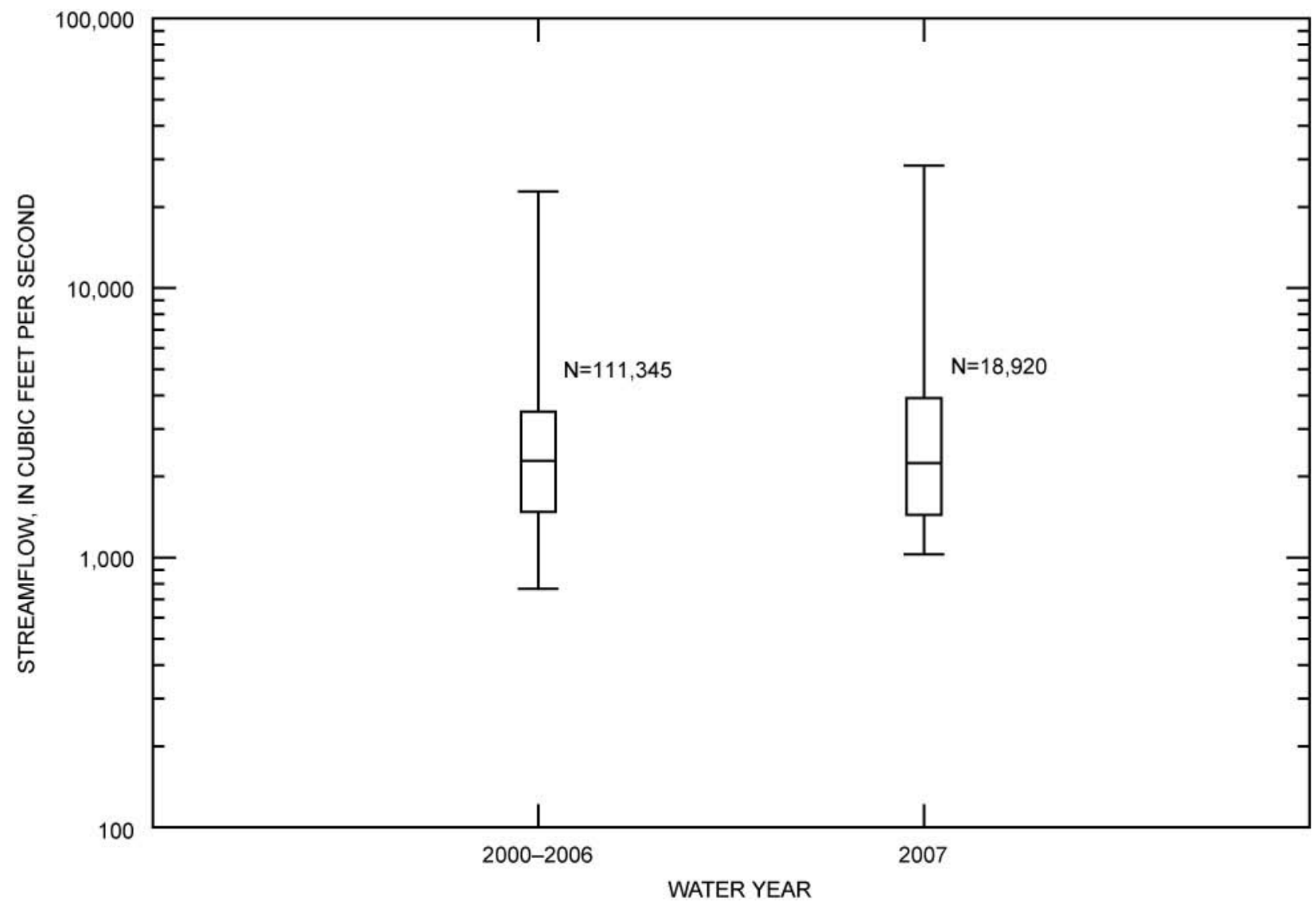

Figure 48. Graph showing comparison of water year 2007 streamflow data with combined data from water years 2000-06 recorded at the Mehama monitoring station, North Santiam River basin, Oregon. 


\section{Turbidity}

- Overall turbidity was only slightly higher in WY 2007 than in previous years (fig. 49), but monthly values in November and December of WY 2007 were much higher than in the past (figs. 46 and 47). A new peak was established in December.

- In water years prior to 2007, 3.7 percent of values were greater than $10 \mathrm{FNU}$ and 0.6 percent of values were greater than $50 \mathrm{FNU}$. In WY 2007, 9.0 percent of values were greater than $10 \mathrm{FNU}$ and 1.8 percent of values were greater than $50 \mathrm{FNU}$.

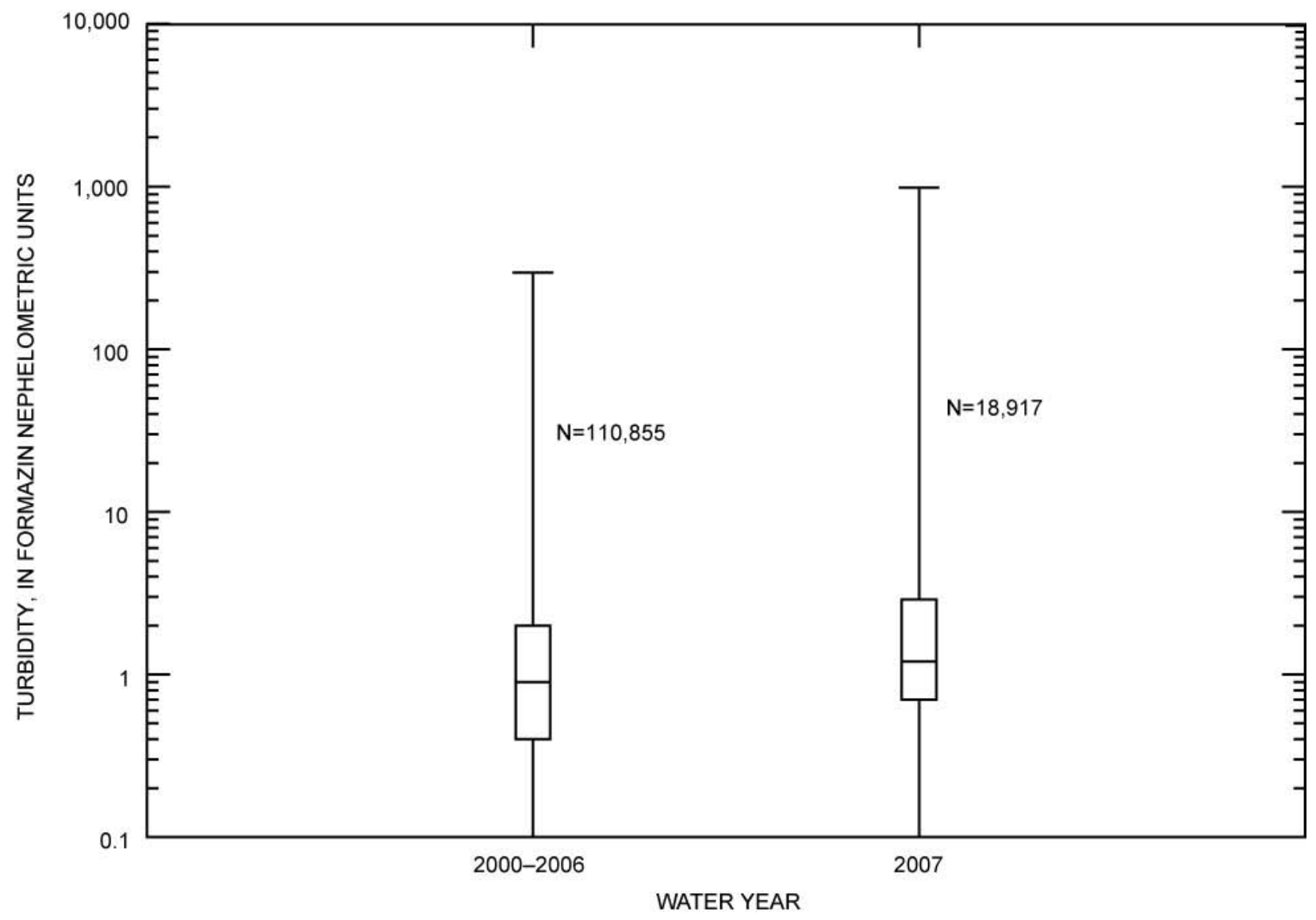

Figure 49. Graph showing comparison of water year 2007 turbidity data with combined data from water years 2000-06 recorded at the Mehama monitoring station, North Santiam River basin, Oregon. 


\section{Water Temperature}

- Water temperatures trended slightly higher in WY 2007 relative to combined data from prior years (fig. 50).

- $\quad$ Record high monthly water temperatures occurred in February, May, and June of WY 2007 (figs. 46 and 47).

- Record low monthly water temperatures for the period of study occurred during November, January, April, and September of WY 2007.

- The Core Coldwater Habitat standard $\left(16^{\circ} \mathrm{C}\right)$ was exceeded in June, July, and August of WY 2007 and in at least some prior years.

- $\quad$ Spawning period standards $\left(13^{\circ} \mathrm{C}\right)$ were exceeded in October, May, June, and September of WY 2007 and in at least some prior years.

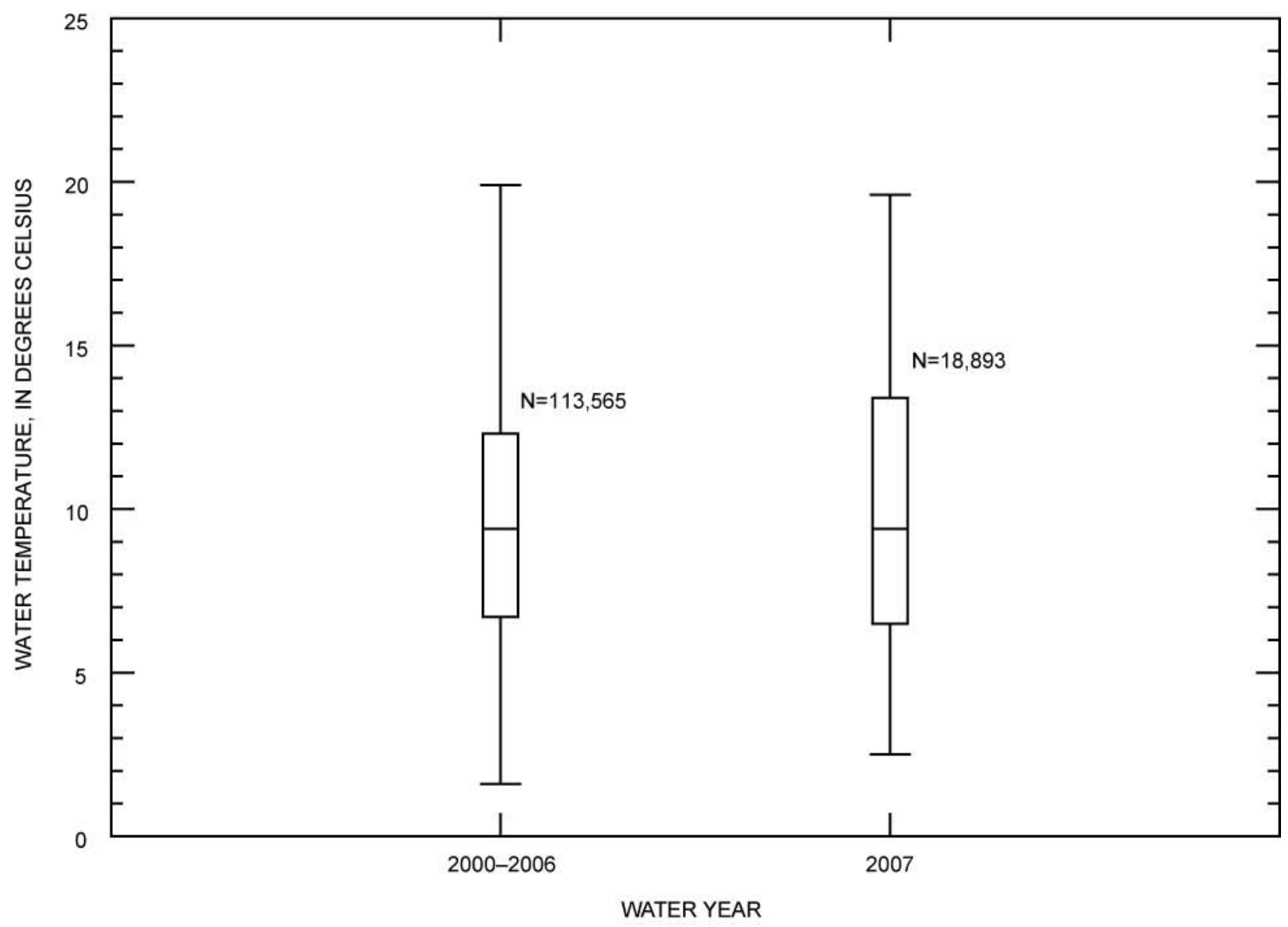

Figure 50. Graph showing comparison of water year 2007 water-temperature data with combined data from water years 2000-06 recorded at the Mehama monitoring station, North Santiam River basin, Oregon. 
$\mathrm{pH}$

- $\mathrm{pH}$ values in WY 2007 were similar to those in previous years, but a new peak for the period of study of 9.1 units was established in September (figs 46, 47, and 51).

- State standards for $\mathrm{pH}$ are frequently exceeded at Mehama, most often the 8.5 maximum.

- $\quad$ New monthly maximum pH values occurred in July, August, and September 2007.

- A new monthly minimum pH was established in November 2006.

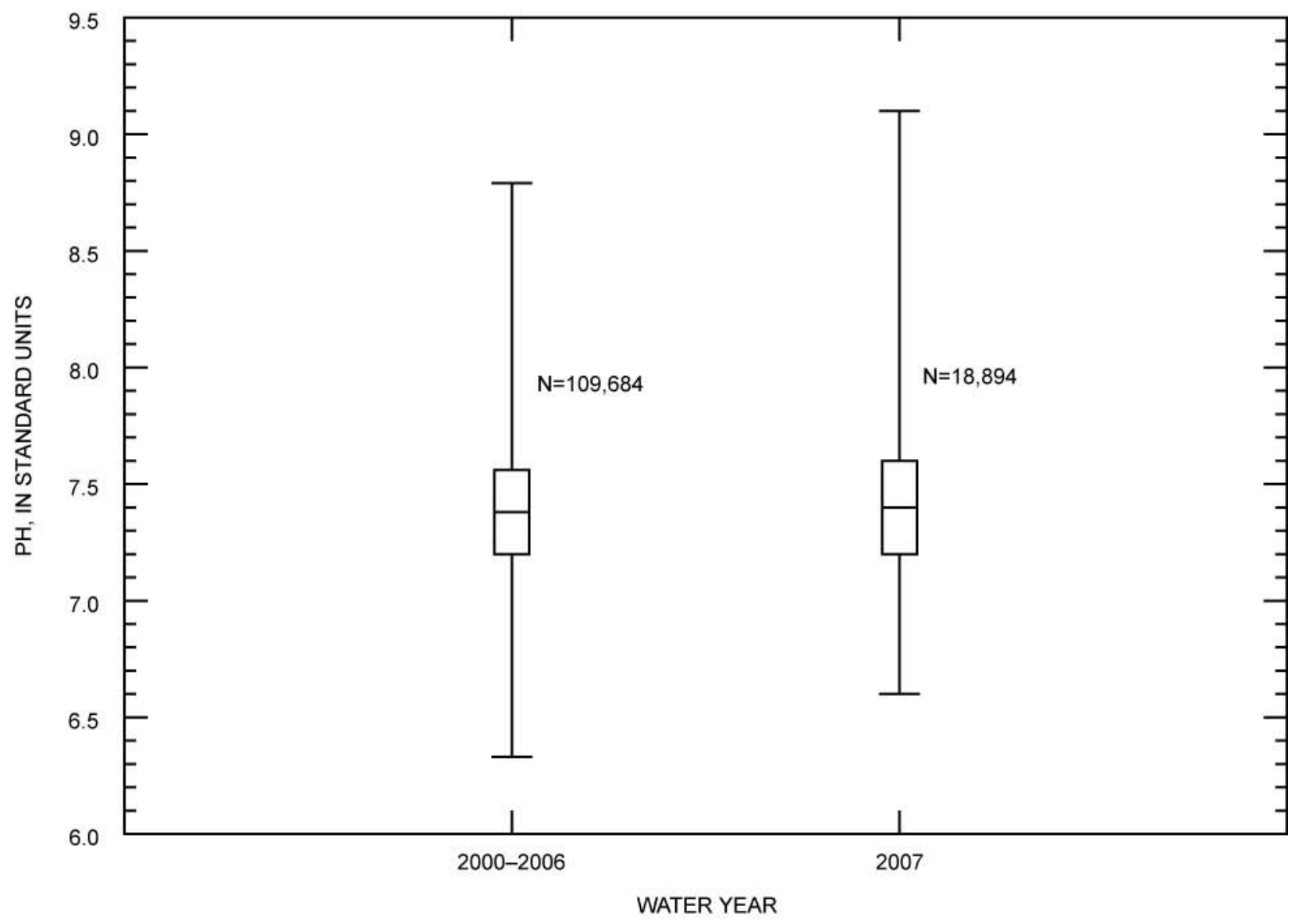

Figure 51. Graph showing comparison of water year 2007 pH data with combined data from water years 2000-06 recorded at the Mehama monitoring station, North Santiam River basin, Oregon. 


\section{Specific Conductance}

- Specific conductance is generally low at Mehama (figs. 46, 47, and 52) One-quarter of the WY 2007 values were lower than $30 \mu \mathrm{S} / \mathrm{cm}$, and no values were greater than $50 \mu \mathrm{S} / \mathrm{cm}$.

- The monthly minimum specific conductance value was equaled in December 2006 (WY 2007)(fig. 47).

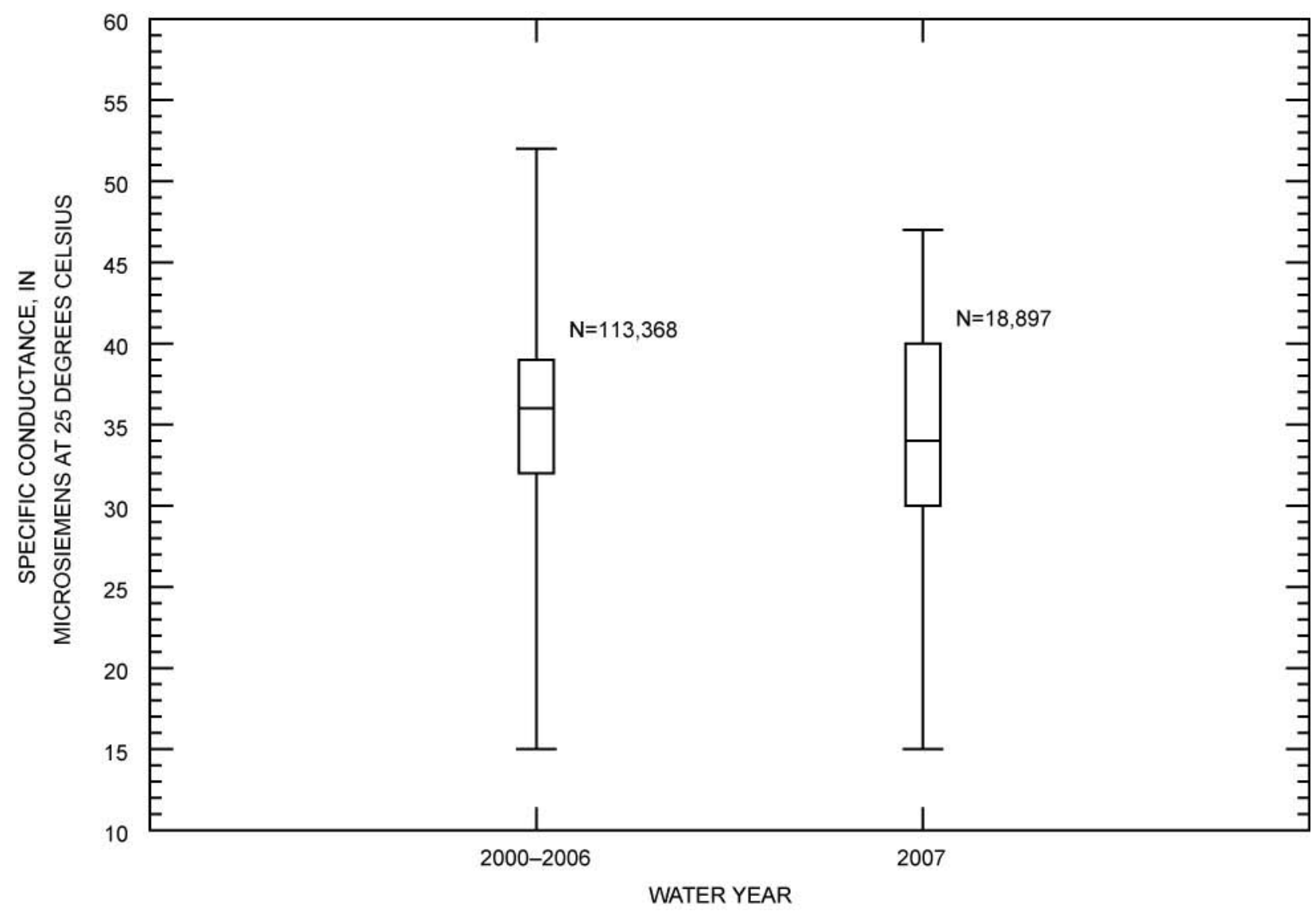

Figure 52. Graph showing comparison of water year 2007 specific conductance data with combined data from water years 2000-06 recorded at the Mehama monitoring station, North Santiam River basin, Oregon. 


\section{North Santiam River at Geren Island near Stayton (Geren)}

The monitor recorded nontelemetered data from March 2001 through June 2004, and the data have been telemetered from June 2004 to present (figs. 53 and 54).
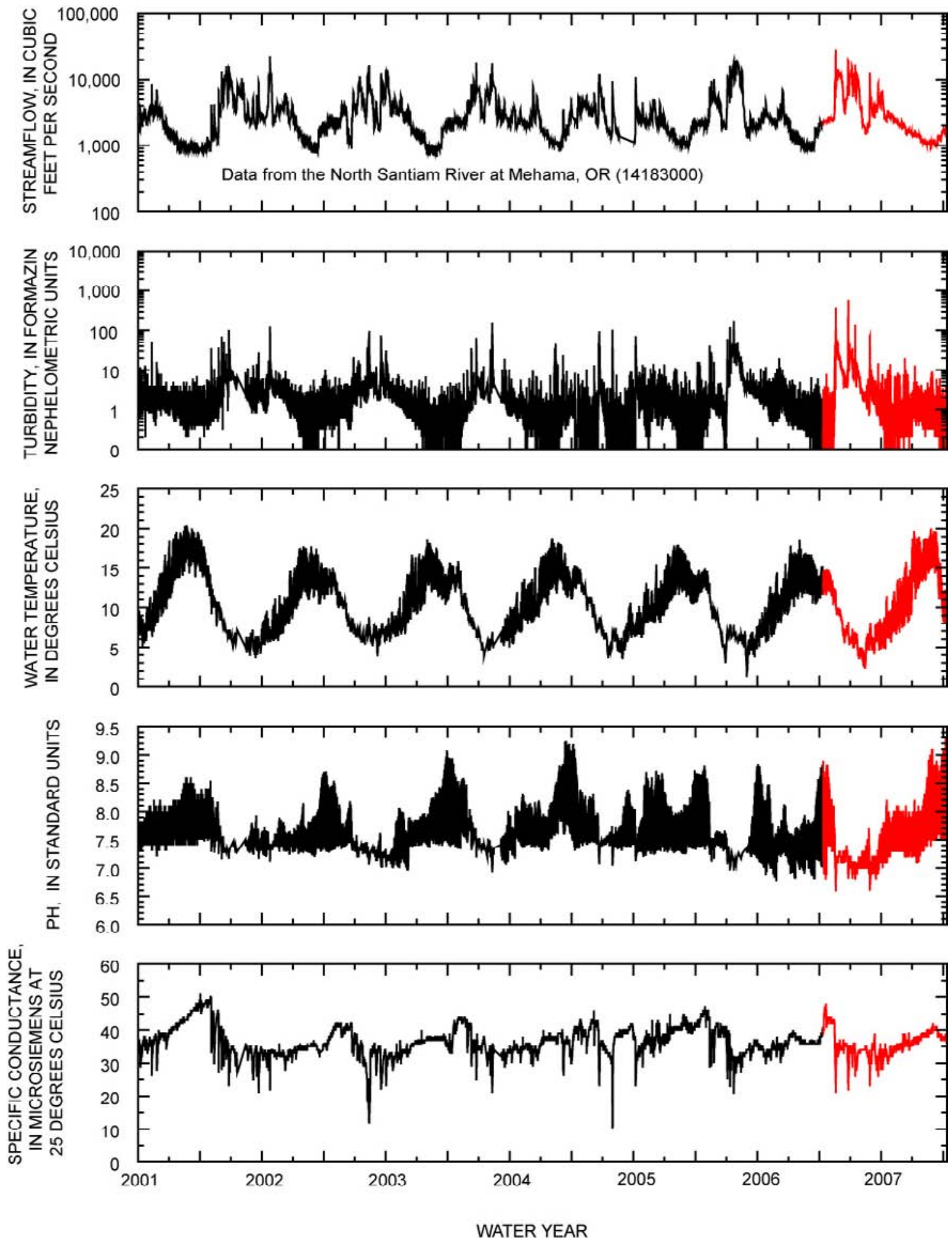

Figure 53. Graphs showing continuous values recorded at the Geren monitoring station, North Santiam River basin, Oregon, for the period of record through water year 2007. 

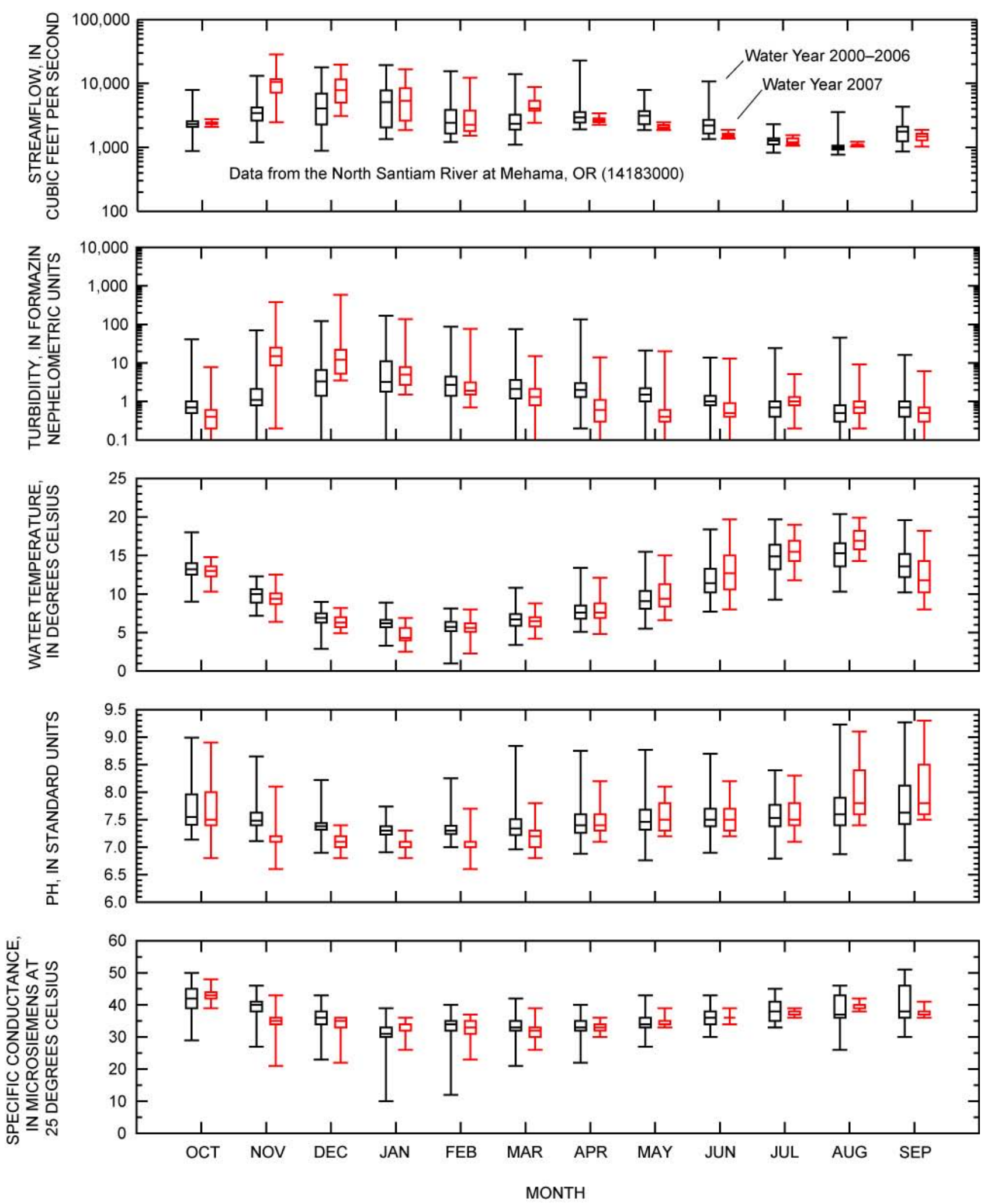

Figure 54. Graphs showing comparison of monthly water year 2007 turbidity, water temperature, pH, and specific conductance to water year 2001-06 values recorded at the Geren monitoring station, North Santiam River basin, Oregon. 


\section{Streamflow}

Streamflow data have not been collected at this station by the U.S. Geological Survey; streamflow from Mehama is used as a surrogate during data processing.

\section{Turbidity}

- WY 2007 turbidity values were much higher in November and December than in the past (figs. 53, 54, and 55). A new maximum monthly turbidity value was established in November, and the December value was a new peak for the period of study.

- In water years prior to 2007, 3.7 percent of values were greater than $10 \mathrm{FNU}$ and 0.4 percent of values were greater than 50 FNU. In WY 2007, 11.3 percent of values were greater than $10 \mathrm{FNU}$ and 1.2 percent of values were greater than $50 \mathrm{FNU}$.

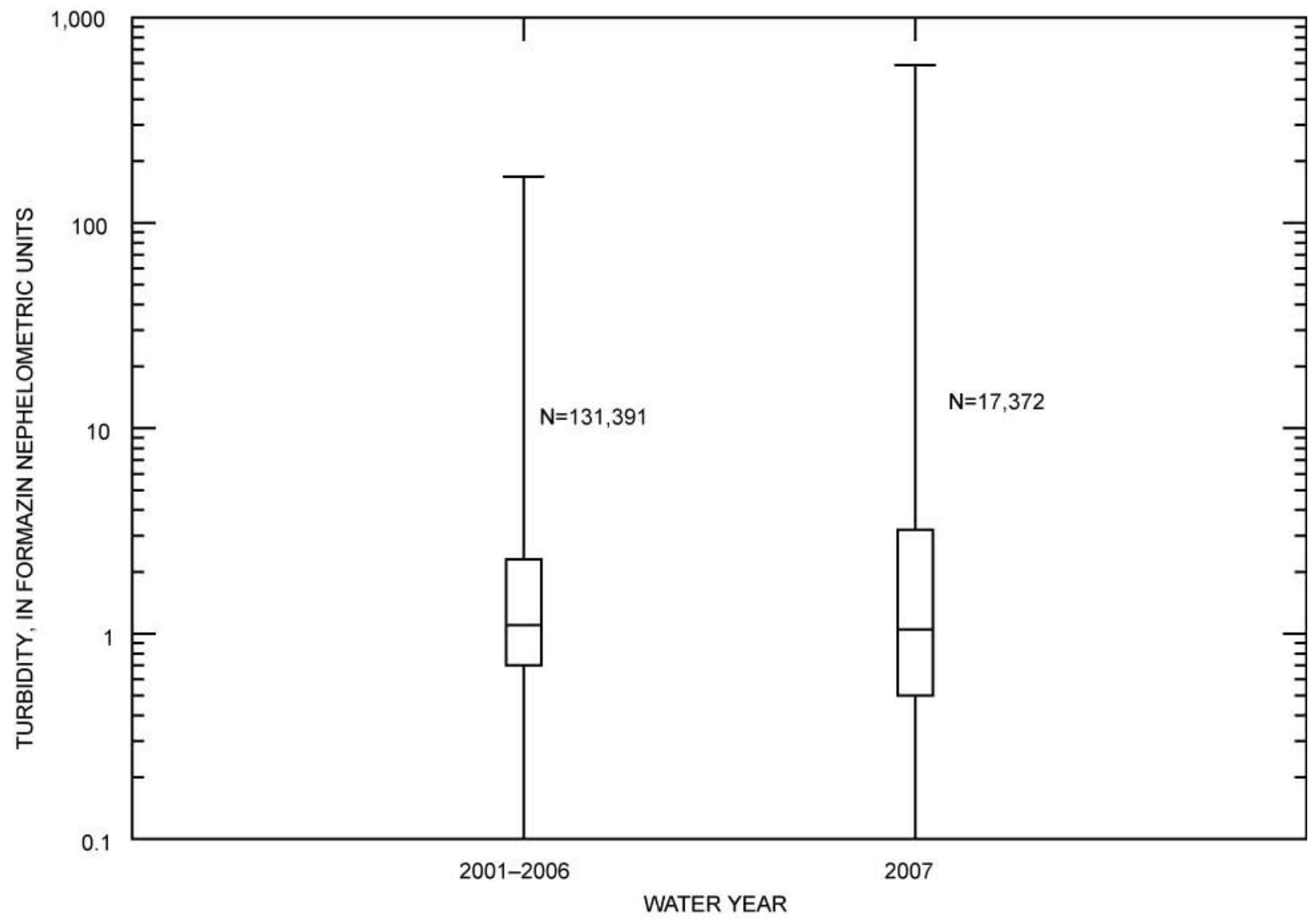

Figure 55. Graph showing comparison of water year 2007 turbidity data with combined data from water years 2001-06 recorded at the Geren monitoring station, North Santiam River basin, Oregon. 


\section{Water Temperature}

- Water temperatures in WY 2007 were similar to those of past years (figs. 53, 54, and 56).

- State temperature standards are frequently exceeded at this site. The Oregon water temperature standard for Core Coldwater habitats $\left(16^{\circ} \mathrm{C}\right)$ was exceeded in June, July, and August 2007 (fig. 54). Water temperatures have exceeded Core Coldwater habitats standards in June, July, and August in at least one water year prior to 2007.

- The standard for Spawning habitat $\left(13^{\circ} \mathrm{C}\right)$ was exceeded in October, May, and September of WY 2007 (fig. 54). Values have exceeded $13^{\circ} \mathrm{C}$ in October, April-June, and September in water years prior to 2007.

- New monthly maximum temperatures were recorded in November and June of WY 2007 (fig. 54).

- New monthly minimum temperatures were recorded in November, January, April, and September of WY 2007 (fig. 54).

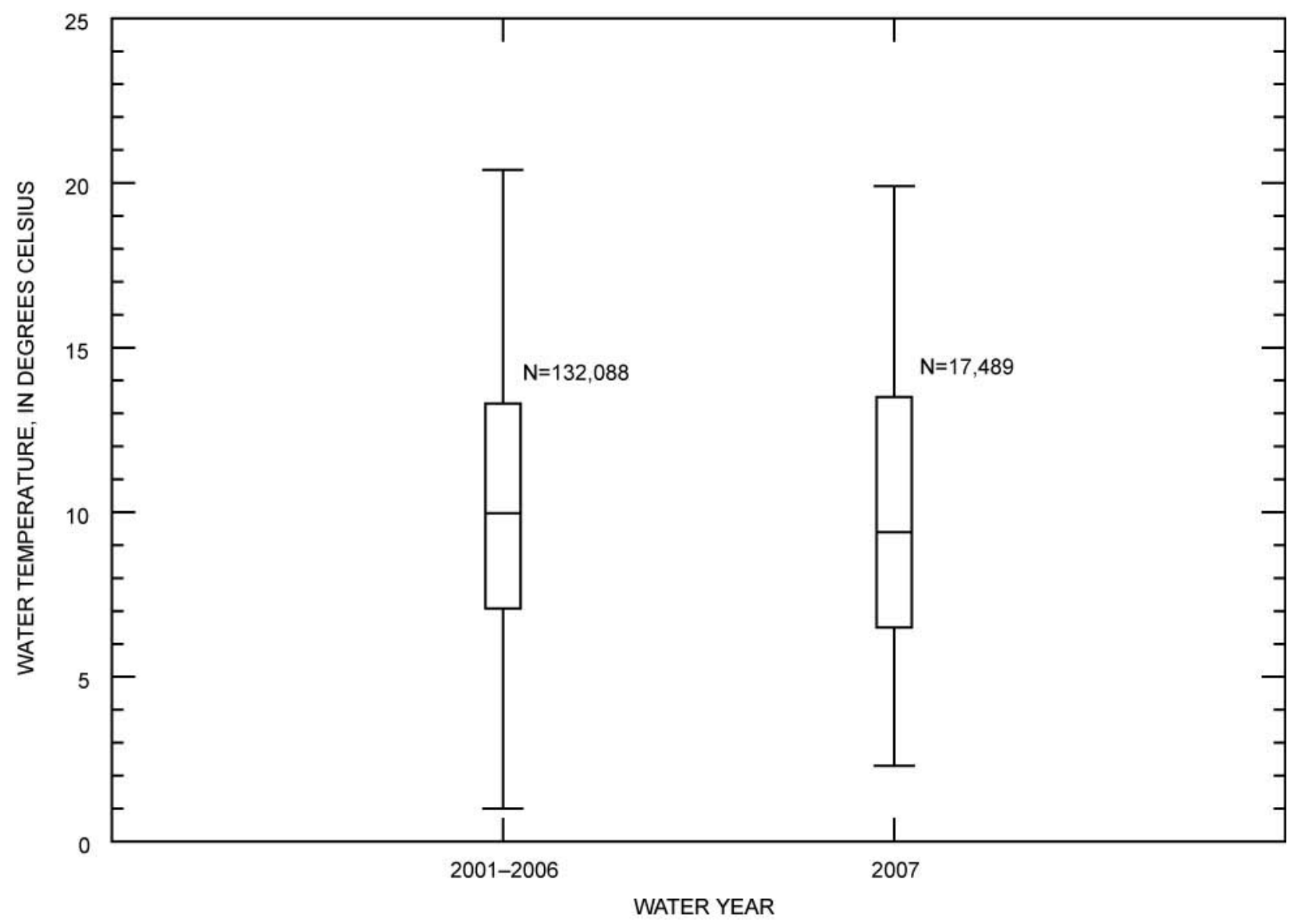

Figure 56. Graph showing comparison of water year 2007 water temperature data with combined data from water years 2001-06 recorded at the Geren monitoring station, North Santiam River basin, Oregon. 
- $\mathrm{pH}$ values were, on average, somewhat lower during WY 2007 than in previous years, mainly because of unusually low values during the high flow months of winter and spring (figs. 53 and 54).

- $\mathrm{pH}$ values at this site occasionally exceed the State maximum pH standard of 8.5 units (figs. 53, 54, and 57).

- In water years prior to 2007, 1.7 percent of values were greater than 8.5 units, whereas in WY 2007, 4.0 percent of values were greater than 8.5 units. However, one-quarter of values exceeded the standard in September 2007.

- A new maximum pH value for the period of study was recorded in September 2007 (fig. 54).

- New monthly minimum values were recorded during October-March of WY 2007 (fig. 54).

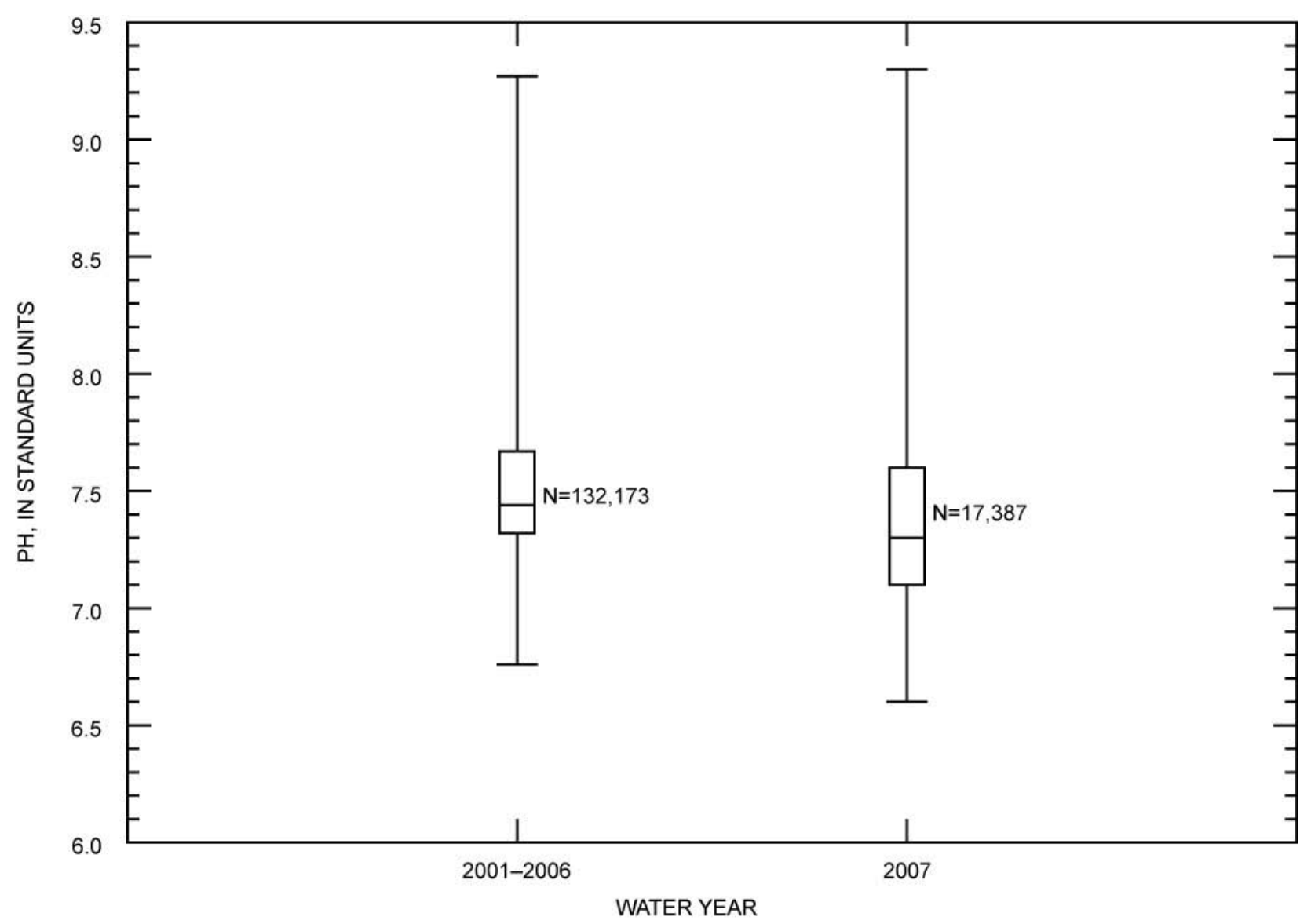

Figure 57. Graph showing comparison of water year $2007 \mathrm{pH}$ data with combined data from water years 2001-06 recorded at the Geren monitoring station, North Santiam River basin, Oregon 


\section{Specific Conductance}

- Specific conductance values are generally low at Geren (fig. 58).

- New monthly minimum specific conductance values were established in November and December of WY 2007 (fig. 54).

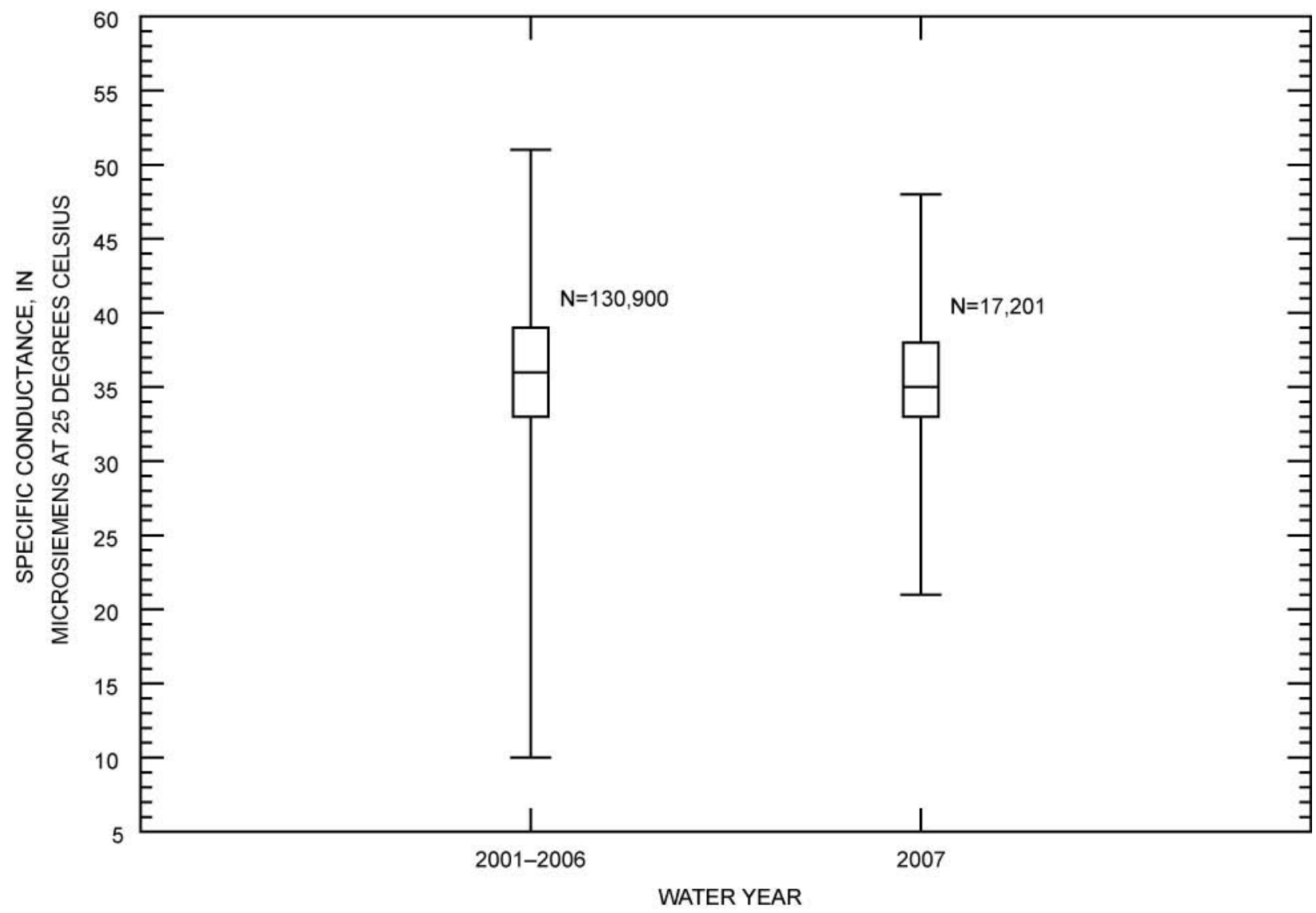

Figure 58. Graph showing comparison of water year 2007 specific conductance data with combined data from water years 2001-06 recorded at the Geren monitoring station, North Santiam River basin, Oregon. 


\section{Dissolved Oxygen}

Dissolved oxygen was added at this station in May 2003 and was discontinued at the end of September 2004 (fig. 59).

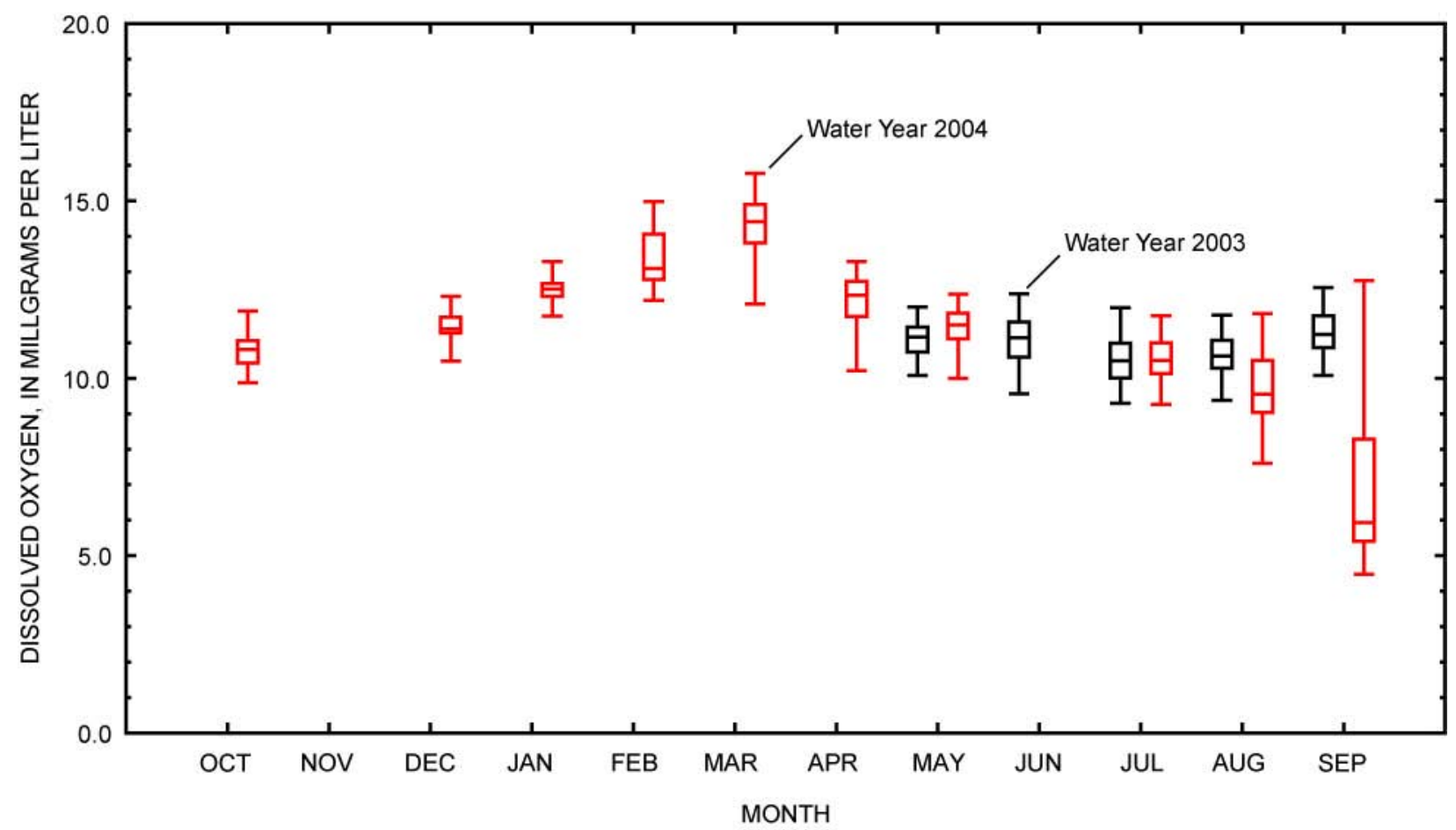

Figure 59. Graph showing dissolved oxygen data for part of water year 2003 and all of water year 2004 from the Geren monitoring station, North Santiam River basin, Oregon. 


\section{Occurrences of Unusually Low or High Values}

\section{Streamflow}

In streamflow data, the "p5" and "p95" designations are the 5th and 95th, percentile streamflows. The percentile values are based on long-term streamflow data for each station. Streamflow that is less than the 5th percentile is very low, and streamflow greater than the 95th percentile is very high relative to typical conditions in a stream. For mainstem sites downriver of Detroit and Big Cliff Dams, p5 and p95 were calculated using data starting with WY 1955, the first full water year after the installation of Big Cliff Dam. Calculations for all other sites were made using all the available data.

WY 2007 had a basinwide flood event in the winter followed by low streamflow conditions at most stations as the summer progressed. All of the stations except Niagara recorded values less than p5 in 2007 (fig. 60). At Breitenbush, Blowout, and Little North, more than 15 percent of values were less than p5. The tributary stations were affected more by low streamflows than the mainstem stations.

In all cases during WY 2007, except Rock, a greater percentage of each station's streamflow exceeded p95 than during the respective periods of study. Niagara and Mehama data had the largest percentages exceeding p95, with 9 percent or more values being greater than the associated p95. Streamflow at these sites is regulated by Big Cliff Dam.

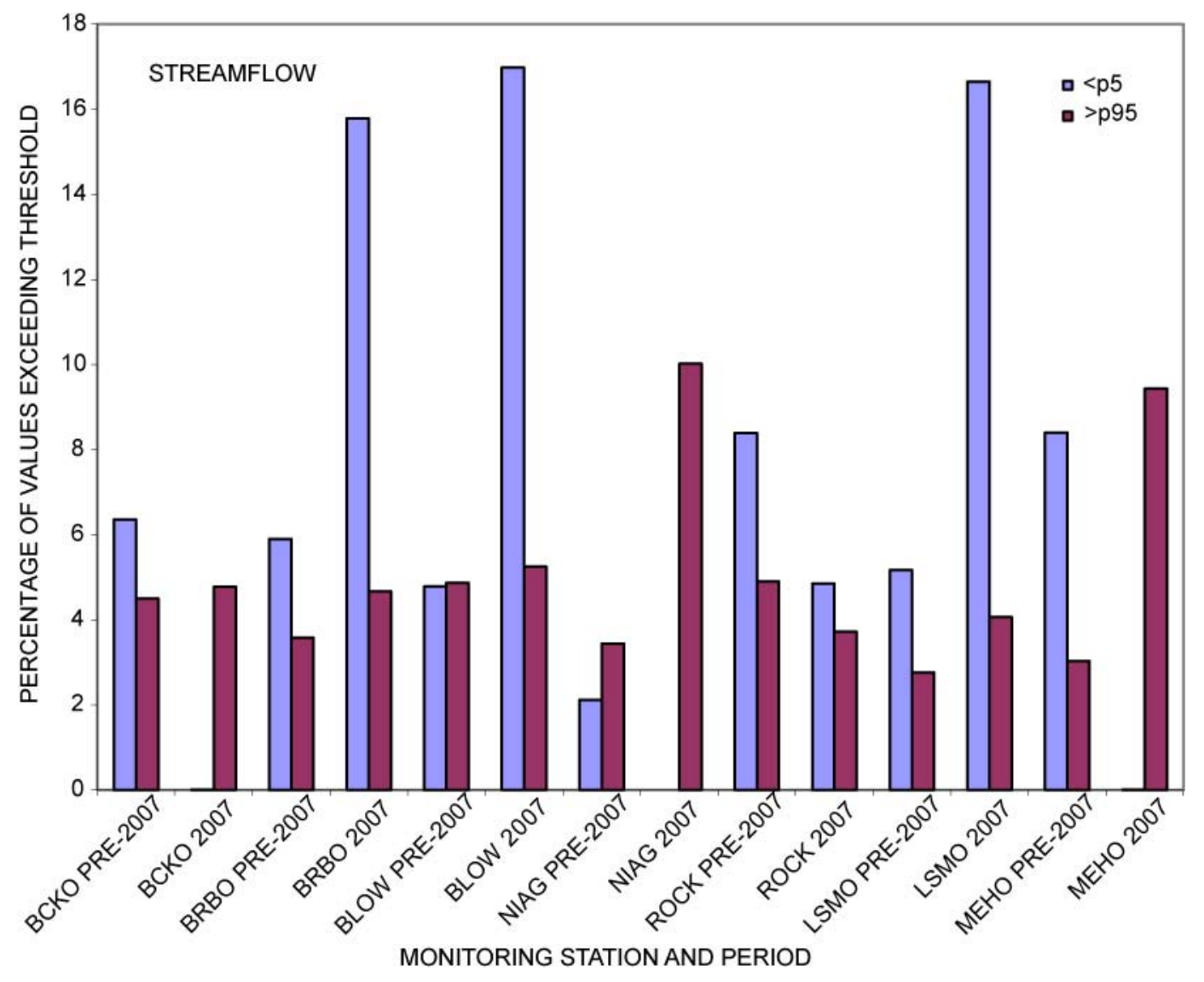

Figure 60. Graph showing the percentage of streamflow values recorded at monitoring stations in the North Santiam River basin, Oregon, that exceeded the p5 and p95 threshold values in water year 2007 and during the period of record preceding water year 2007. See table 1 for station name abbreviations. 


\section{Turbidity}

Throughout the North Santiam River basin, every station recorded turbidity greater than 50 FNU during WY 2007, as well as in previous years (except Niagara). At all stations except Rock, however, the percentages of values greater than $10 \mathrm{FNU}$ and 50 FNU were greater in WY 2007 than in prior years (fig. 61). The percentage of values greater than $50 \mathrm{FNU}$ at mainstem monitoring stations in WY 2007 was greater than three times those in the pre-2007 data.

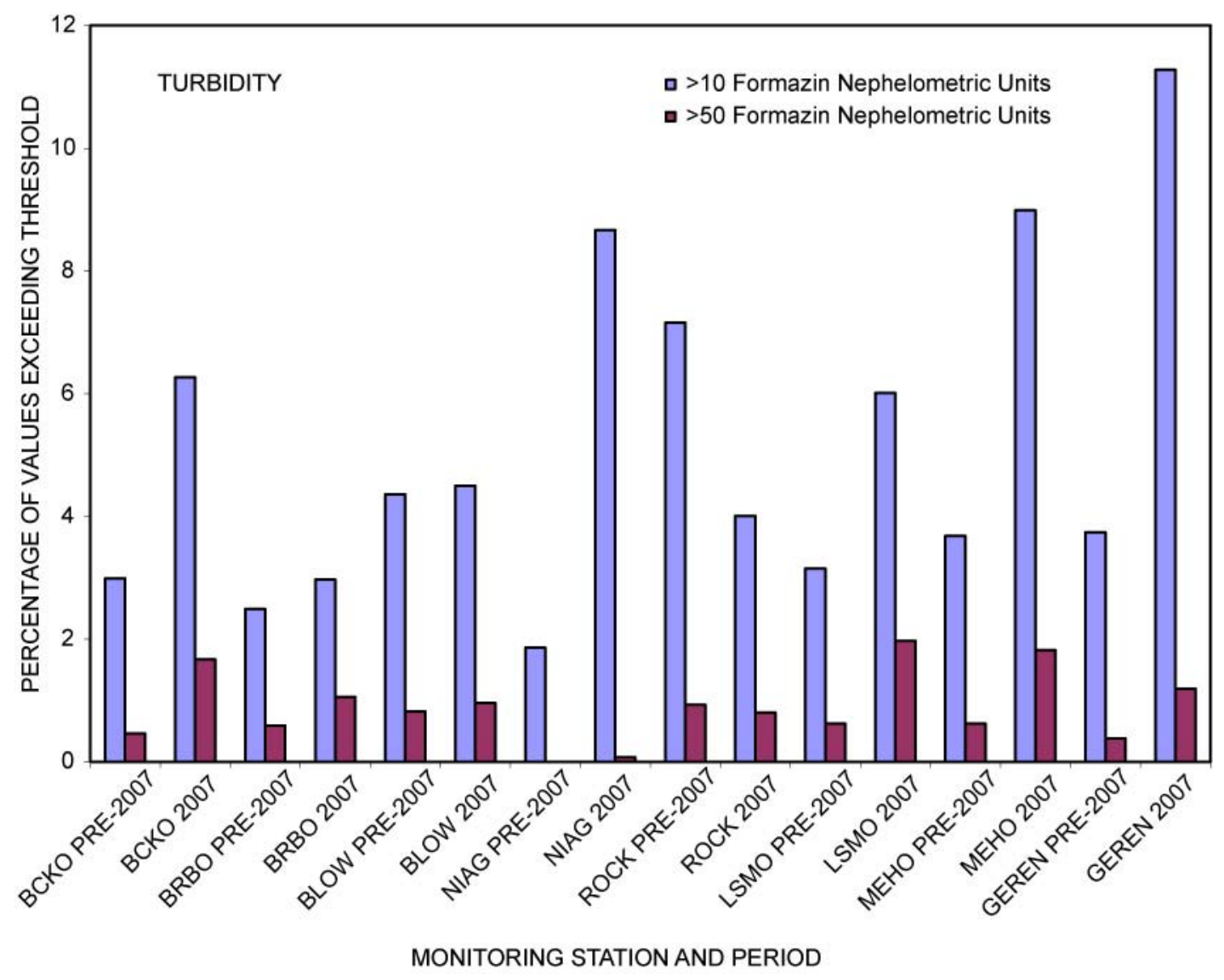

Figure 61. Graph showing the percentage of turbidity values recorded at monitoring stations in the North Santiam River basin, Oregon, that exceeded the $10 \mathrm{FNU}$ and $50 \mathrm{FNU}$ threshold in water year 2007 and during the period of record preceding water year 2007. See table 1 for station name abbreviations. 


\section{Water Temperature}

The State standard for water temperature specifies that it should not exceed $13^{\circ} \mathrm{C}$ from September 1 through June 15 and $16^{\circ} \mathrm{C}$ from June 16 through August 31 at all mainstream and tributary stations downriver of Detroit and Big Cliff Dams. Temperature at the stations upriver of the dams should not exceed $18^{\circ} \mathrm{C}$ at any time during the year. The State standard specifies a 7-day running average to determine a violation. Values in this report are instantaneous, not an average; therefore, exceedences of standards noted herein are not necessarily violations.

Instantaneous water temperature values exceeded the Core Cold Water Habitat Use standard $\left(16^{\circ} \mathrm{C}\right)$ at all lower-basin stations at least once during WY 2007 and in previous years. Further, instantaneous water temperature exceeded the Spawning standard at one time or another $\left(13^{\circ} \mathrm{C}\right)$ at all the stations during the period of study.

Values at stations upriver of the dams, except Blowout, have not exceeded the Rearing and Migration Standard $\left(18^{\circ} \mathrm{C}\right)$ during the period of record. Values at Blowout exceeded the standard in WY 2007 and in prior water years; however, a greater percentage of data were greater than $18^{\circ} \mathrm{C}$ in $\mathrm{WY}$ 2007 than during WY 1999-2006.

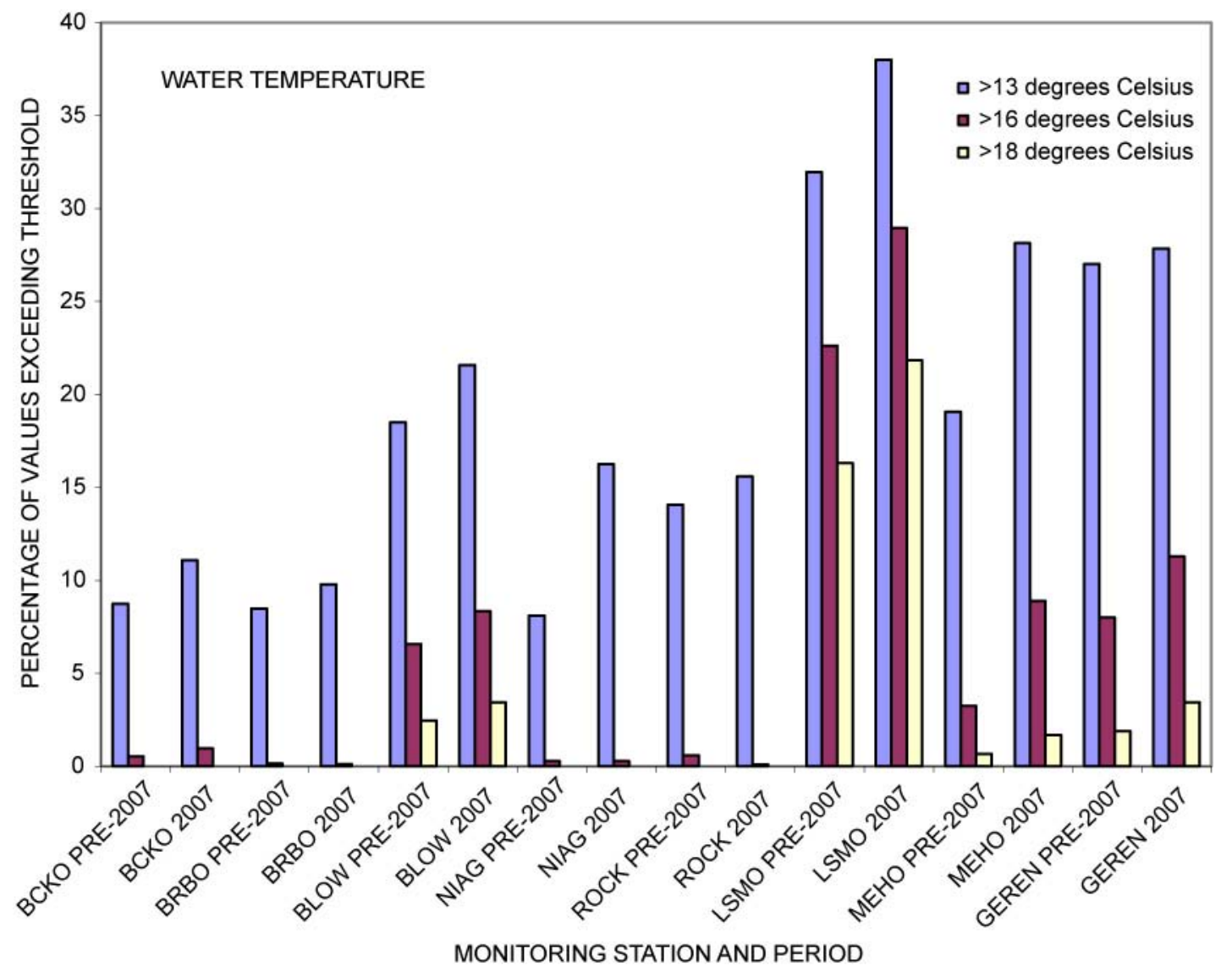

Figure 62. Graph showing the percentage of water temperature values recorded at monitoring stations in the North Santiam River basin, Oregon, that exceeded the $13^{\circ} \mathrm{C}, 16^{\circ} \mathrm{C}$, and $18^{\circ} \mathrm{C}$ threshold values in water year 2007 and during the period of record preceding water year 2007. See table 1 for station name abbreviations. 
$\mathrm{pH}$

State standards for $\mathrm{pH}$ in streams of the Willamette River Valley allow values within the range of 6.5-8.5 units. Any values outside of this range are considered to be in violation. The standard applies no running average and makes no provision regarding the source(s) of low or high $\mathrm{pH}$ values.

Only two stations, Little North and Mehama, have recorded values less than $6.5 \mathrm{pH}$ units (fig. 63). At both stations, less than 1 percent of values were less than that value prior to WY 2007, and in WY 2007, only about 1 percent of the data were less than the threshold at Little North.

The 8.5 unit standard was exceeded at North Santiam, Little North, Mehama, and Geren at some time during the period of study. Little North recorded less than 1 percent of pre-WY 2007 values greater than 8.5 units, and no WY 2007 values exceeded that. Prior to WY 2007, Mehama had some percentage of values (less than 0.5 percent) that exceeded the standard, and in WY 2007, about 1 percent of the values were greater than 8.5 units. Pre-WY 2007 values at Geren exceeded the State standard with less than 2 percent of values, and WY 2007 values exceeded the standard about 4 percent of the time, although about 25 percent of values were greater than the standard in August-September.

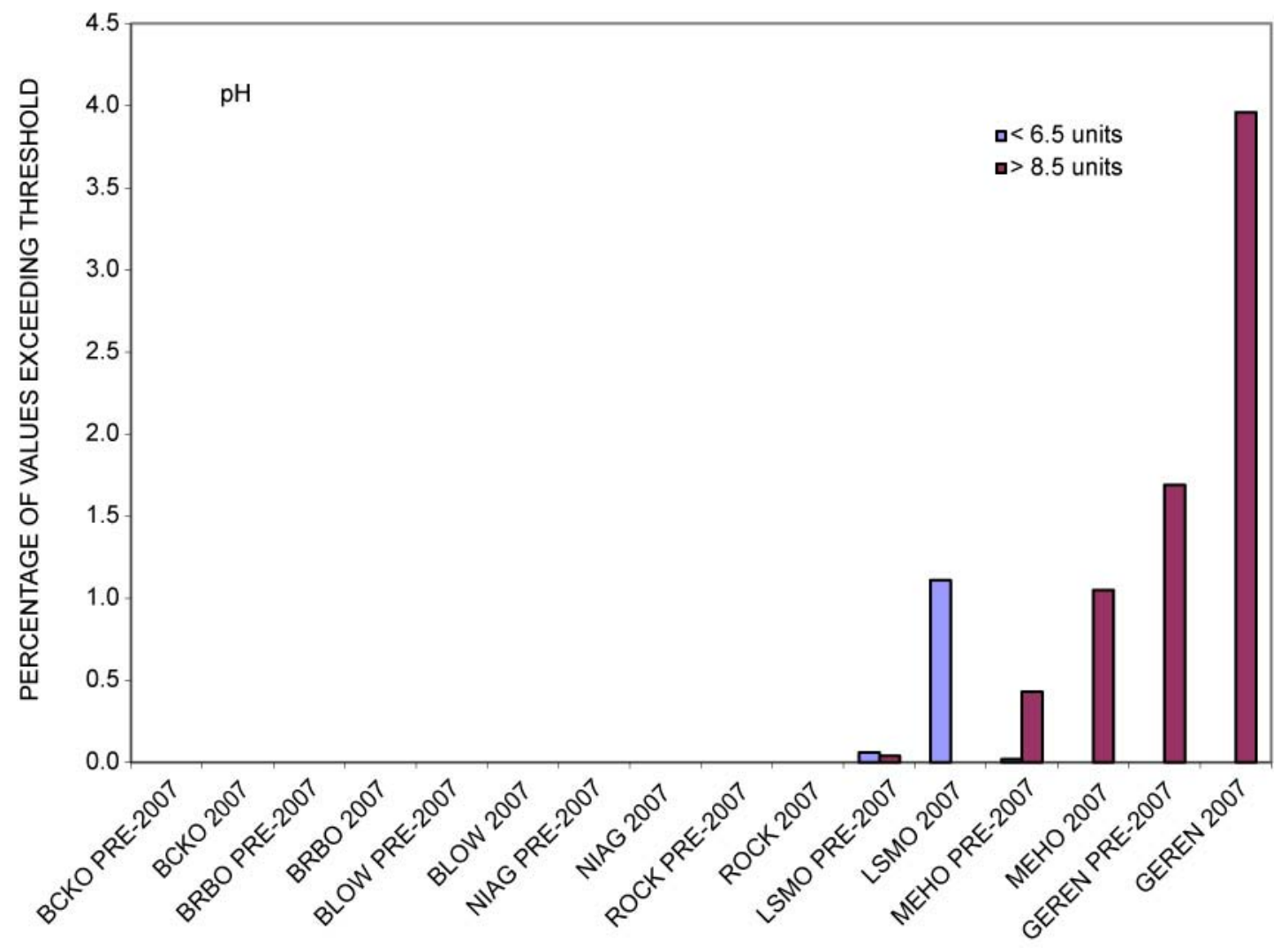

MONITORING STATION AND PERIOD

Figure 63. Graph showing the percentage of $\mathrm{pH}$ values recorded at monitoring stations in the North Santiam River basin, Oregon, that exceeded the 6.5 and 8.5 standard unit threshold values in water year 2007 and during the period of record preceding water year 2007. See table 1 for station name abbreviations. 


\section{Specific Conductance}

The State of Oregon has no standard for specific conductance. For purposes of this report, the values of 30 and $50 \mu \mathrm{S} / \mathrm{cm}$ were assigned as a minimum and maximum threshold, respectively. Data typically occur outside of this range only during unusual circumstances, such as during high or low streamflow condition. Typical specific conductance values differ among subbasins. A value outside of the $30-50 \mu \mathrm{S} / \mathrm{cm}$ range is not necessarily indicative of a problem.

For all stations, at least 1 percent of specific conductance values were less than $30 \mu \mathrm{S} / \mathrm{cm}$ in both pre-WY 2007 data and WY 2007 data. More values were less than $30 \mu \mathrm{S} / \mathrm{cm}$ for the lower-basin stations than for the upper-basin stations, and the percentages between pre-WY 2007 data and WY 2007 data were roughly similar. With the exception of Rock, where the range for specific conductance is broad, fewer percentages of values also were greater than $50 \mu \mathrm{S} / \mathrm{cm}$ for the lower-basin stations than for the upper-basin stations. No values were greater than $50 \mu \mathrm{S} / \mathrm{cm}$ for Niagara and Geren during WY 2007 or in prior years. For Mehama, no values were greater than $50 \mu \mathrm{S} / \mathrm{cm}$ in WY2007 and less than 1 percent of values were greater than the threshold value in past data.

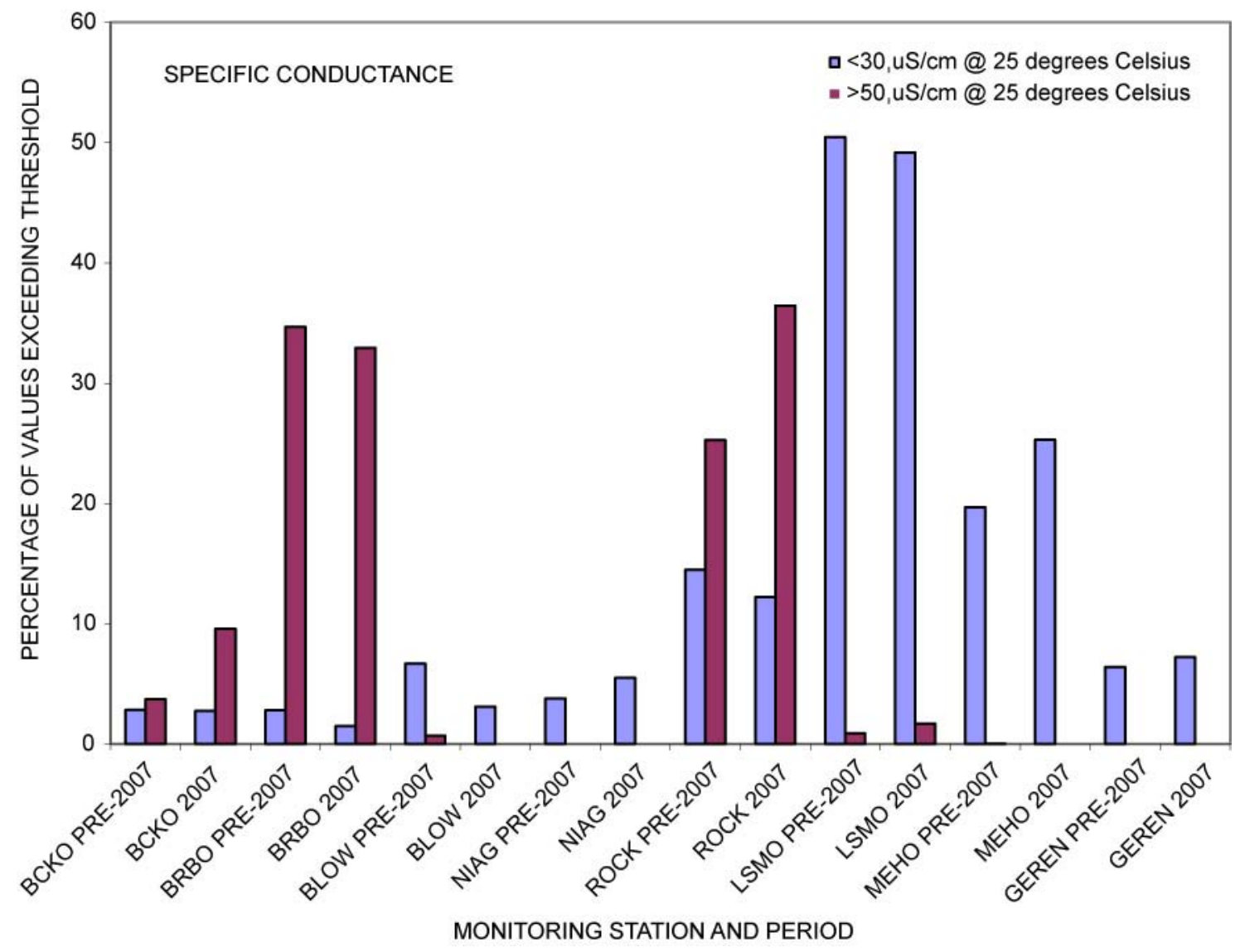

Figure 64. Graph showing the percentage of specific conductance values recorded at monitoring stations in the North Santiam River basin, Oregon, that exceeded the 30 and $50 \mu \mathrm{S} / \mathrm{cm}$ threshold values in water year 2007 and during the period of record preceding water year 2007. See table 1 for station name abbreviations. 


\section{Summary}

\section{Water Quality in Water Year 2007}

\section{Streamflow}

The winter was wetter than normal and the summer was drier than normal in WY 2007. Streamflows in October and early November of WY 2007 were comparable to those of the previous water years of study in the regulated mainstem, downstream of the dams; however, in the tributaries, October and early November streamflow was generally less than in previous water years. November storms quickly increased streamflows in the basin to levels much above November normals of previous years of record. High streamflows for the period of study occurred in November or December of WY 2007 at all lower basin monitoring stations except the North Santiam River at Niagara (Niagara), the first streamflow-gaging station downstream of the dams. New monthly peaks for November and December were established at that site, however. All stations had higher median streamflows for March 2007 than in past years.

During April-September of WY 2007, median streamflows generally were less than median values of previous years. Lowest or near lowest monthly streamflows were recorded at all tributary stations since the beginning of the period of study in October, early November, May, June, and July of WY 2007. Values in August and September were less than the pre-WY 2007 median at those stations (except Rock, which has insufficient record to make meaningful inter-year comparisons).

\section{Turbidity}

Early winter storms caused elevated turbidity throughout the basin. Except for Breitenbush River above French Creek near Detroit (Breitenbush) and Blowout Creek near Detroit (Blowout), all stations recorded monthly maximum turbidities in November and December of WY 2007. Turbidity at Niagara gradually decreased in spring as sediment from the upper basin completed its migration through Detroit Lake.

A debris flow in the North Santiam River basin upstream from Detroit Lake in November resulted in turbidity as high as an estimated 30,000 FNU at the North Santiam River below Boulder Creek near Detroit monitoring station (North Santiam). Sediment from the event was detected at Niagara a few days later, indicating that some of the sediment from the debris flow passed through Detroit and Big Cliff reservoirs in suspension. During the rest of WY 2007, basinwide turbidity values were generally comparable to pre-WY 2007 values.

Greatly elevated turbidity during the winter at the North Santiam River at Geren Island near Stayton monitoring station (Geren) was caused primarily by suspended sediment from the Little North Santiam River. The basis for this conclusion is that turbidity values at the Little North Santiam River near Mehama (Little North) and North Santiam River at Mehama (Mehama) monitoring stations were as much as an order of magnitude higher than at Niagara during the same period.

\section{Water Temperature}

Most WY 2007 water temperatures were within the ranges of past water years during any given month; however, lower basin mainstem sites had higher than normal values in summer. January water temperatures were on the low side of normal compared to water years prior to 2007 throughout the 
basin. One or more of Oregon's water-temperature standards were exceeded in WY 2007 and in past years.

$\mathrm{pH}$

Most sites in the basin recorded lower than normal pH values in winter of WY 2007, and somewhat to much higher than normal pH values (relative to pre-WY 2007) in the summer, especially the lowerbasin mainstem sites. New monthly minimum values were recorded during November and/or December at the lower basin stations. New monthly maximum $\mathrm{pH}$ values were recorded at most stations beginning as early as May. The low (6.5 standard units) and high (8.5 standard units) State $\mathrm{pH}$ standards were exceeded a small percentage of the time at lower basin stations during the period of study.

Specific Conductance

Specific conductance values were somewhat lower in winter and higher in summer of WY 2007 than in past years; however, no values were unusually low or high.

\section{Acknowledgements}

Special thanks to the City of Salem for their funding of the North Santiam Turbidity Study, their essential input into the operation and maintenance of the monitoring network, and their expertise. The authors are especially grateful to Tim Sherman, Hank Wujcik, and the other dedicated staff at the City of Salem water treatment facility for their assistance and guidance.

Thanks also to the U.S. Forest Service Detroit Ranger District employees Dave Klug, Dave Halemeier, and others, who were valuable sources of information about the North Santiam basin and who provided other assistance when needed.

John Koenig of the U.S. Army Corp of Engineers is essential in keeping many of the installations transmitting data, as is the entire U.S. Geological Survey Portland Field Office crew, particularly Greg Olsen and Doug Cushman. Jay Spillum, Scott Deweese, and others are thanked for station construction and repair. Adam Stonewall, Scott Deweese, Glen Hess, and Tom Herrett greatly assisted in clarifying streamflow collection methods and reporting.

Finally, the authors acknowledge the guidance of Joseph Rinella and John Williams of the USGS.

\section{References Cited}

Anderson, C.W., 2005, Turbidity, chap. 6.7 of National field manual for the collection of water-quality data: U.S. Geological Survey Techniques of Water-Resource Investigation 09-A6.7, 55 p. (Also available at http://water.usgs.gov/owq/FieldManual/Chapter6/6.7_contents.html.)

Bragg, H.M., and Uhrich, M.A., 2005, The North Santiam River, Oregon, water-quality monitoring network: U.S. Geological Survey Fact Sheet 2004-3069, 6 p. (Also available at http://pubs.usgs.gov/fs/2004/3069/.)

Bragg, H.M., Sobieszczyk, Steven, Uhrich, M.A., and Piatt, D.R, 2007, Suspended-sediment loads and yields in the North Santiam River basin, Oregon, water years 1999-2004: U.S. Geological Survey Scientific Investigations Report 2007-5187, 26 p. (Also available at http://pubs.usgs.gov/sir/2007/5187/.) 
Cooper, R.M., 2005, Estimation of peak discharges for rural, unregulated streams in Western Oregon: U.S. Geological Survey Scientific Investigations Report 2005-5116, 134 p. (Also available at http://pubs.usgs.gov/sir/2005/5116/.)

Rantz, S.E., and others, 1982, Measurement and computation of streamflow: U.S. Geological Survey Water-Supply Paper 2175, 2 volumes, 631 p. (Also available at http://pubs.usgs.gov/wsp/wsp2175/.)

Sobieszczyk, Steven, Uhrich, M.A., and Bragg, H.M., 2007, Major turbidity events in the North Santiam River basin, Oregon, water years 1999-2004: U.S. Geological Survey Scientific Investigations Report 2007-5178, 50 p. (Also available at $h t t p: / / p u b s . u s g s . g o v / s i r / 2007 / 5178 /$.)

Sobieszczyk, Steven, Uhrich, M.A., Piatt, D.R., and Bragg, H.M., 2008, Analysis of geomorphic and hydrologic characteristics of Mount Jefferson debris flow, Oregon, November 6, 2006: U.S. Geological Survey Scientific Investigations Report 2008-5204, 18 p. (Also available at http://pubs.usgs.gov/sir/2008/5204/.)

State of Oregon, 2008, Water quality standards-Beneficial uses, policies, and criteria for Oregon: Oregon Department of Environmental Quality, accessed June 28, 2010, at http://arcweb.sos.state.or.us/rules/OARs_300/OAR_340/340_041.html.

Uhrich, M.A., and Bragg, H.M., 2003, Monitoring in-stream turbidity to estimate continuous suspended-sediment loads and yields and clay-water volumes in the Upper North Santiam River basin, Oregon, 1998-2000: U.S. Geological Survey Water-Resources Investigations Report 03-4098, 43 p. (Also available at $h t t p: / / p u b s . u s g s . g o v / w r i / W R I 03-4098 /$.

U.S. Geological Survey, 2009, Annual water data reports: U.S. Geological Survey Web site, accessed August 9, 2010, at http://wdr.water.usgs.gov/.

Wagner, R.J., Boulger, R.W., Jr., Oblinger, C.J., and Smith, B.A., 2006, Guidelines and standard procedures for continuous water-quality monitors-Station operation, record computation, and data reporting: U.S. Geological Survey Techniques and Methods 1-D3, 51 p. + 8 attachments; accessed April 10, 2006, at http://pubs.water.usgs.gov/tm1d3. 
